1.

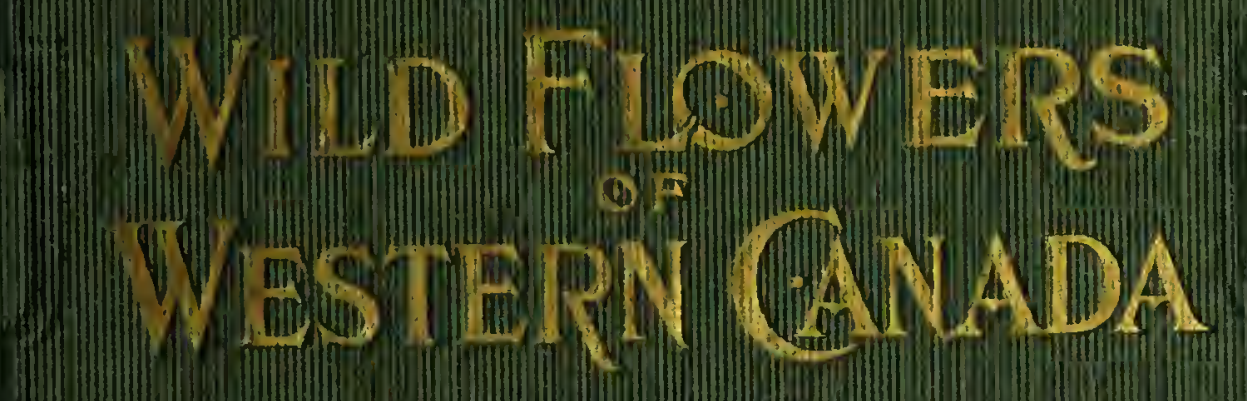




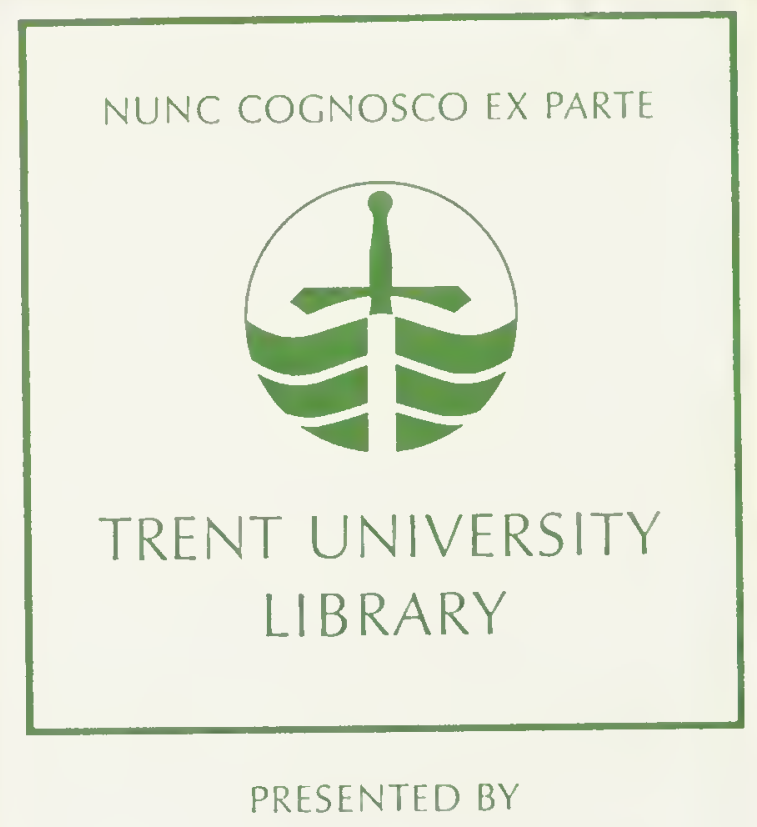

Mrs. H.H. Graham 
Digitized by the Internet Archive in 2019 with funding from Kahle/Austin Foundation 





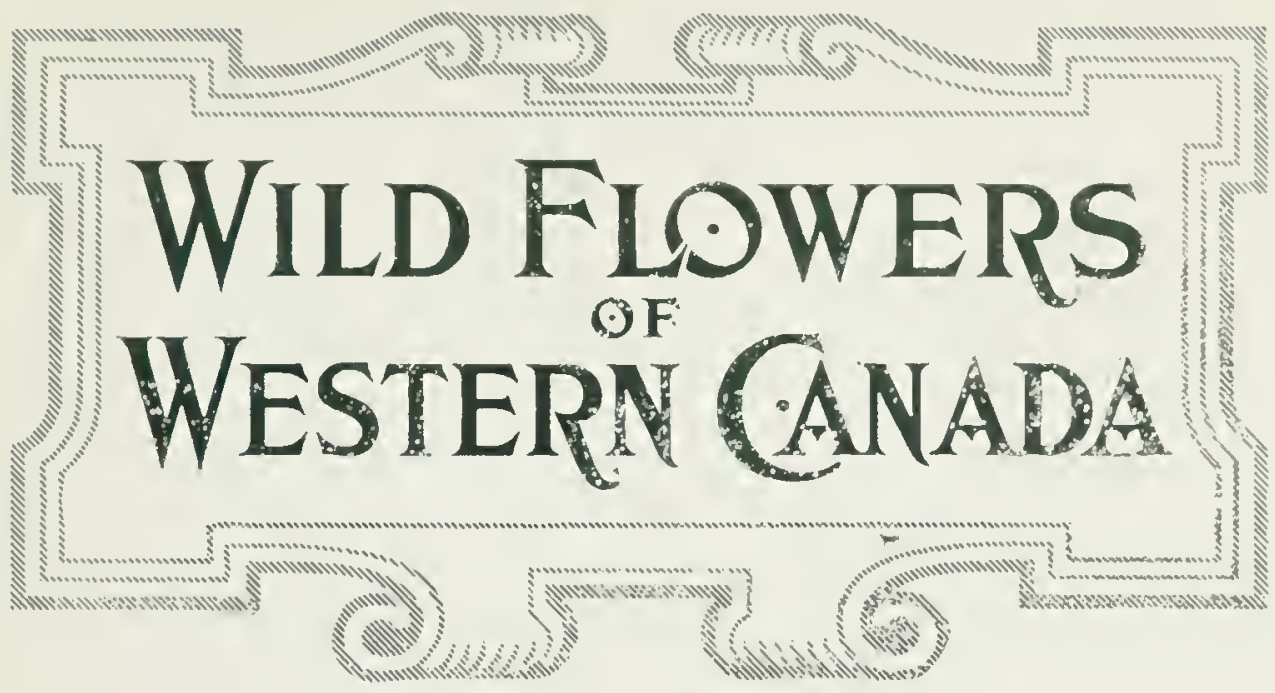

$\mathrm{By}$

WILLIAM COPELAND MCCALLA

With Sixty Plates from Original Photographs by the Author

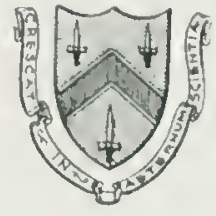

TORONTO

THE MISSON BOOK COMPANY

I.I.MITEED 
Copyright, Canada, 1920 by

W. C. McCalla 
MARGARET 


\section{NATURE}

"The bubbling brook doth leap when I come by, Because my feet find measure with its call;

The birds hnow when the friend they lore is nigh, For I am known to them, both great and small. The flower that on the lonely hillsille grouls Expeets me there when spring its blomm has given, And many "tree and bush my wenderings linome's, And e'en the clouds and silent stars of hraven;" 


\section{PRFFACE}

The plants pictured and clescribed in this litte book are for the most part guite common in Western Canadia. With a territory so vast and varied in chatucter as is ours, the realer will not expect to find them all in his own noighborhoorl, but he will find many of them, also others quite as heautiful and interesting. He may regret that some favorite flower is not inchuded, hut he may be sure that his regret is shared by the author who found it difficult to make the final selection. No two persons would have male an identical choier, still, it is believel that represontative planti from all parts of the Wrest except the extrome North and the Pacific slope have loeen inclided.

In a general way the plants are arrangel according to their time of bloom, beginning with the early flowers of Spring. But owing to the extent of our comnt $y, 10$ locall conclitions of soil and exposires, and to variations in weather from year to your, it is impossible to be exact as to either order or dites. Still, for a work of this kind, it was felt to be the best arrangement.

In writing of western wild flowers one mects the difficulty that many of them have as yet no gencrally reeognized rommon name. Such namos as far as possible have been hunted out and liserl. In some cuses they lack drfiniteness, ats where a common generic name has rome into use and is applied loosely to any onc or to all of tho several species. To aceurately identify the flower the botanieal name is also given. As the photographs together with the notes on size, eolor, and habitat are believed to be quite sufficient to enable the reaker to reognize any of the plants, it has not been thought necessiry or desirable to give detailed technical deseriptions.

The landseape pietures are introduend to give variety of interest and to direct attention to the fascinating subject of plant societies.

'To know the manc of a flower is, of course, but a preliminary to accuanintanes. It is hoperl that the presentation of erertain facts in the life history of these plants may lead reaters to more attentively observe the plantis :bout them-to notion how they arlapt themselves in strueture and habit to their envignnent, how they bravely meret vicissitules of fortune, how angerly they take advantage of favorable opportmities, and how marvelously in form and service they and the inserets are interedated and mutully depend-

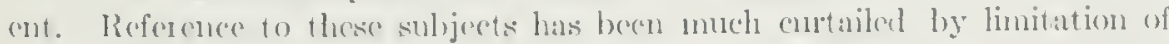

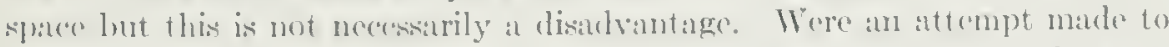
give tho whole lifo history of carele plant it would be attended by two dangers:

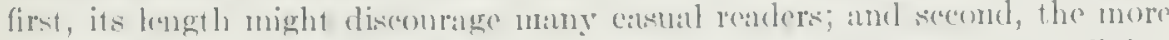

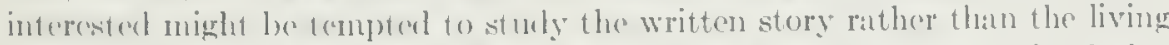
phant. Ilenes, the andeavor has linen to make the brief text stimulative

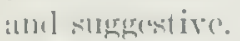

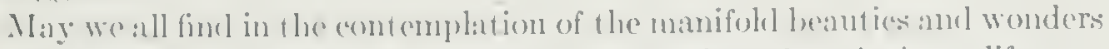

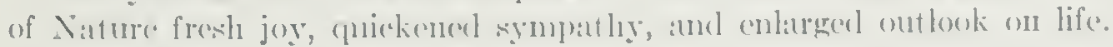

II. ('. MCC MLLA.

(ilonlorooki liarm,

Br(monrer, Ill)(rta,

May 1!20). 



\section{LIST OF ILLUSTRATIONS}

PAGF

Golden Pea............................. 11

Fairy Bclls........................... 13

Wild Sarsaparilla....................... 15

Early Purple Violet...................... 17

Shooting Star......................... 19

Purple Milk Vetch........................ 21

The Forest Invading a Peat Bog. . . . . . . . . . . . . 23

Baked-Apple Berry . . . . . . . . . . . . . . . . 25

Aretic Raspberry......................... 27

Water Arum. . . . . . . . . . . . . . . . . . . . . . 29

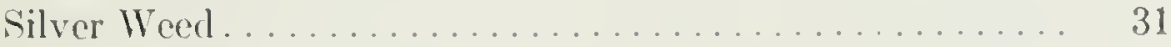

Round-leaved Orchis. . . . . . . . . . . . . . . . . 33

Blue Beard Tongue. . . . . . . . . . . . . . . . . 35

Bird's-cye or Mealy Primrose . . . . . . . . . . . . . 37

Marsh Ragwort. . . . . . . . . . . . . . . . . . 39

Zones of Vegetation around a Pond................ 41

Tall Lungwort. . . . . . . . . . . . . . . . . . . . . . . 43

Yellow Lady's Slipper . . . . . . . . . . . . . . . . . 45

Twin-flower............................ 47

Bunchberry . . . . . . . . . . . . . . . . . . . . . 49

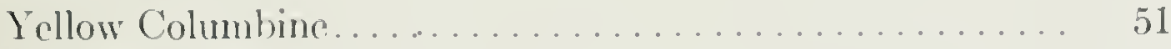

Northern Bedstraw...................... 53

Seneca Snakeroot. . . . . . . . . . . . . . . . . . 55

Red Lily. . . . . . . . . . . . . . . . . . . . 57

In a Western Woodland...................... 59

Pink Wintergreen. . . . . . . . . . . . . . . . . 61

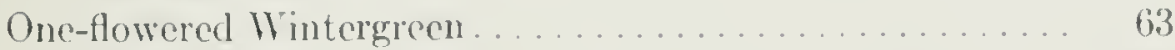

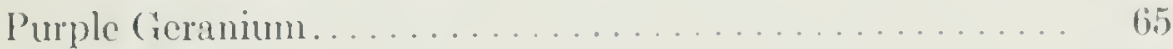

Tall White Cinquefoil......................

Cow Parsnip. . . . . . . . . . . . . . . . . . . . . 69

Prairic Pink. . ......................... 71

Searlet Gaura . . . . . . . . . . . . . . . . . . . .

Purple Prairie Clover ...................... 75

Northern Hedrsitum. ..................... 77 


\section{LAST OF ILLUSTRATIONG}

PAGE

A Flower-bordered Road...................... T9

Hedge Nettle............................. 81

Great-flowered Gaillardia.................... 8.3

Tall Meadow Rue.......................... \$. \$

Loco-rveed ............................... 87

Nodding Wild Onion ...................... 89

Tall or Gilaucous Zygaclenus. . . . . . . . . . . . . . . . 91

Oval-leaved Milkweed ...................... 93

Rough Fleabane Daisy ..................... 9.

Wild Bergamot. ........................ 97

A Ferny Dell............................ 99

Great Willow-herb.......................... 101

Glass of Parnassus........................ 10.3

Spreading Dogbane....................... 105

Giant Hyssop . . . . . . . . . . . . . . . . . . . . . . 107

Wild Moming Glory. . . . . . . . . . . . . . . . . . . . . . 109

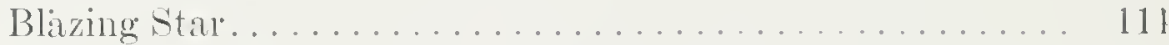

Painted (up........................... 113

A IVestern River feene...................... 115

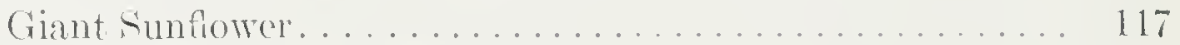

Bromel-loaved Arrow-head . . . . . . . . . . . . . . . . . 119

Marsh Folwort........................... 121

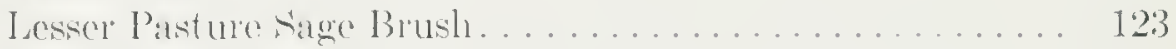

White lonirio Lster. . . . . . . . . . . . . . . . . . 125

Drummond's Dryas. ...................... 127

A Group of dirship Seeds.................... 129 


\section{WILD FLOWERS WESTERN CANADA}




\section{GOLDEN PEA; PRAIRIE BEAN}

\section{Thermopsis rhombifolia (Nutt.) Richards}

\section{Pra Famas}

The early flowers are expecially welcome anel are cigerly looked for. It is an event of the year to fimbl the first ancmone, the well-known "crocus" of the prainie. Following this pioneer" come the swect coltsfoot, a dwalf buttereup, a tiny, leafy-stemmed violet, and, showiest of all, this splemelid Golden Poa. It perfumes and brightens many a hillside and bit of pririe, alwats showing a preference for sandy soil.

When the stalk emerges from the ground it wears a gray coat of silky hairs. Its tip is bent over and sheltered by latge stipules (those leaf-like appendages at the hase of cach leaf-stalk), as if the plant hid its face between huge car talss from the sudklen exposure to wind and sunshine. As the stem glows, the threeparted leaves push out from this protection, but for a time the leaflets remain folder along their mid-ribs, only erahually opening ont and assuming the horizontal position. The flower huts are soon revaled, ancl rapidly develop) into large, luight yollow, poushaped blossoms, followed a fow wereks litter ly sirkle-shaped poels.

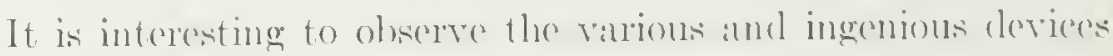
used by plantis to ensure the safety of the tencler goung shoots and leives during the great change from the smmge challe of the lund to the full exposure of maturity. The transition is mstally male without injury. Many people heliere that while manmade gitrlens ane often calught by late frosts and storms, the wild

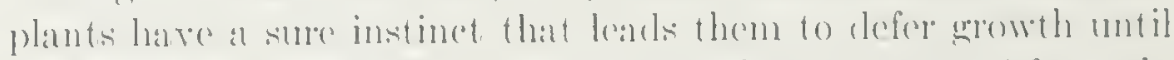
the weather is safe. But this is not wholly remeret. "for only" those who hatre studierl nature lutt very little will mantain that

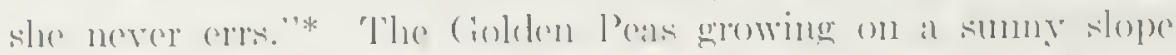

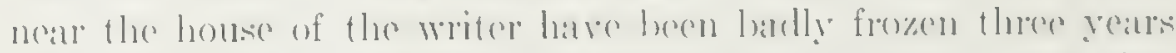

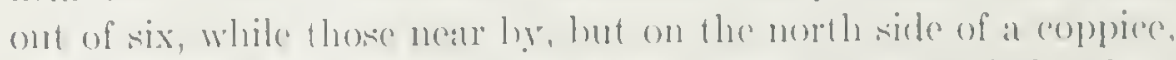

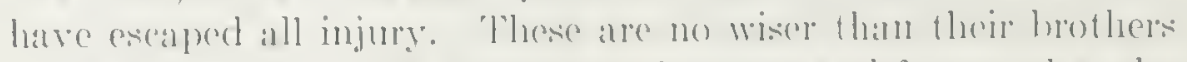
on the litlside, lut the lumsle hold the smow and frost and so delayed their start.

"Maneterliusk. 


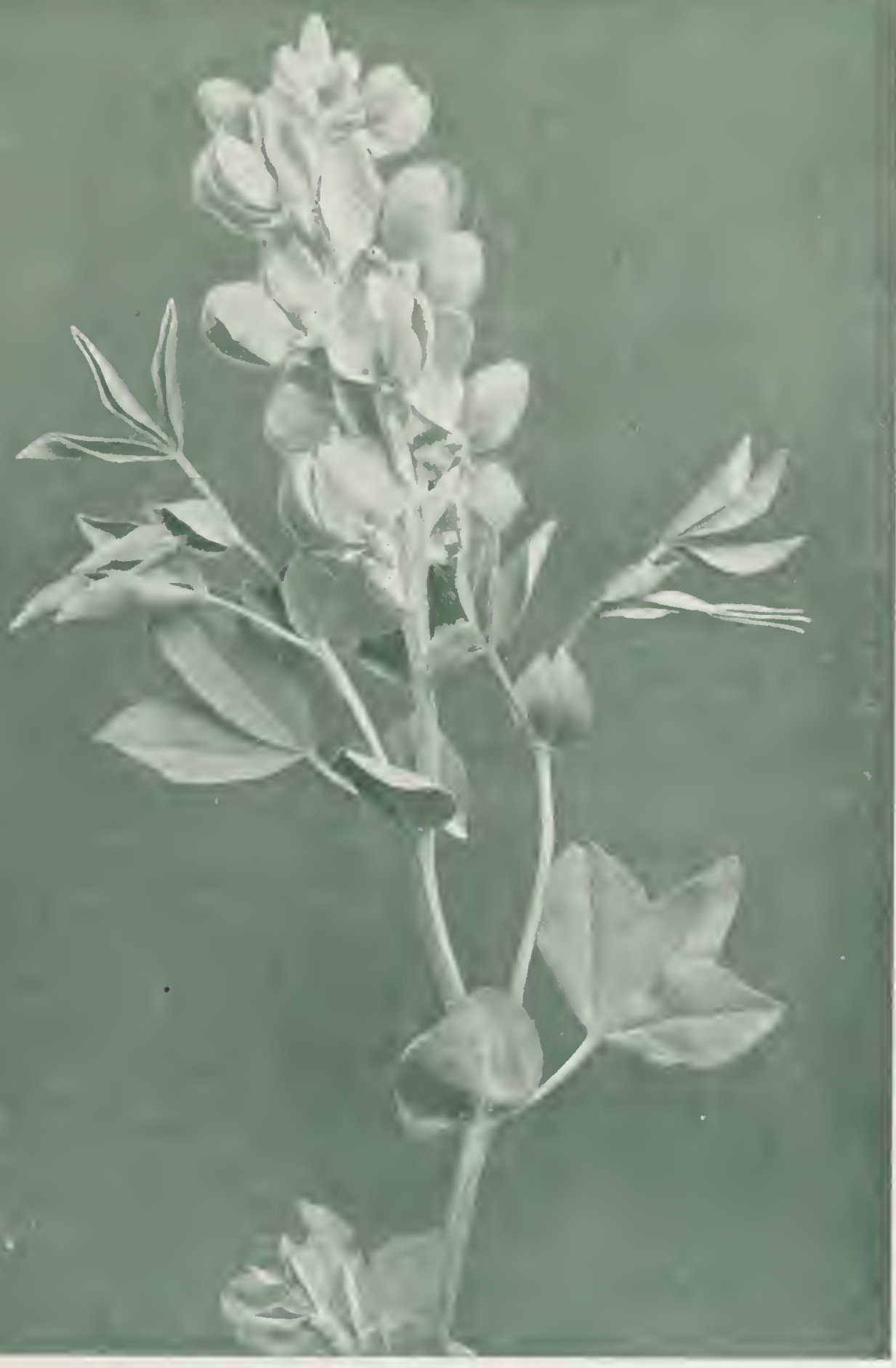

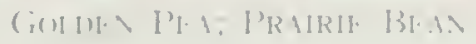




\section{FAIRY BELLS}

\section{Disporum trachycarpum S. Wats.}

IHIX FAMIL

Here is no plant of the open prairie. The thin, soft tissue of it leaves and of its ereamy-white flowers eonld not stand exposure to high wind, beating rain, or strong sunshine, hence it is in deep roods, especially on the sheltered sides of ravines, that this glateful and dainty beauty of early Spring is to be found. How well it ehooses its lome is slown by the fact that this photograph of perfeet speenurens was taken in the morningr, after a late snowstorm, followed by frost, had bedraggled or blighted the hardier plants up in the open.

As the developing foliage of the trees shuts out more sumliglit, the Disporum hroadens out with the ample. horizontal leaves chaladeteristic of woodland undergrowtl. Still later in the season, each branch now widely divergent, bears one or two bright berres where one humg the deliuate bells. These globose, thres-lobed fruits are about one-half inch in diameter, and in process of ripening (llange from green to orange and then to dazzling searlet. Their skin is mimntoly roughened, giving it the riehurs of velvet. Within is a small quantity of juiey pulp and mumenous ivory-white seeds. The bervies, although not likely to he used for human fool, secn larmless enough. These are ripe hefole the leaves assume their antumn tints, so, unless larrien away promptly by the birds, they have first a rich green ambl later a loright yellow baekerround. 


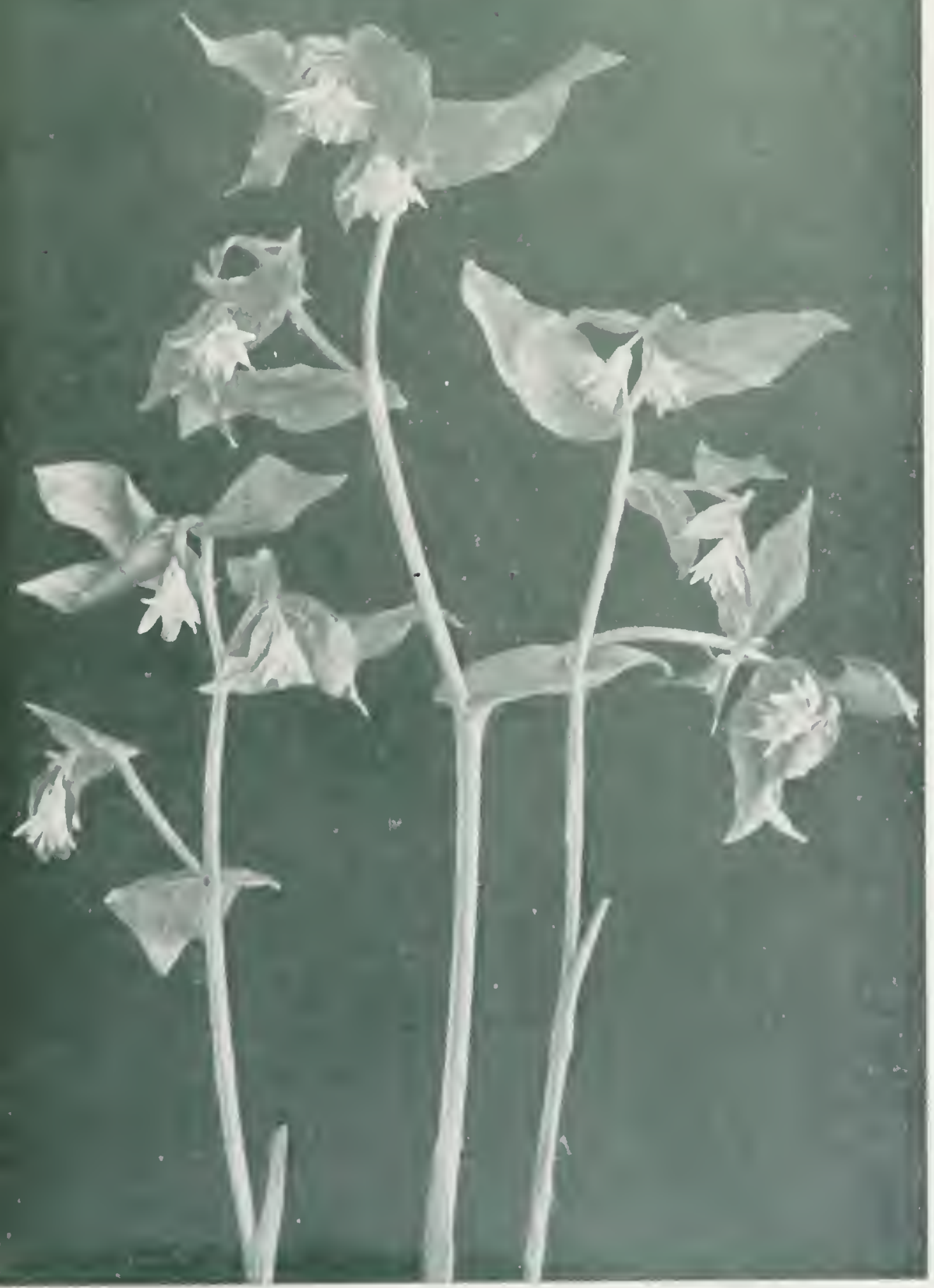

IAIRI BHIS 


\title{
WILD SARSAPARILLA
}

\author{
Aralia nudicaulis $L$.
}

Ginseng Famil

The Wild Sarsaparilla can hardly be ealled a beautiful flower, yet the plant as a whole is attractive, and, for a time in early June, its abundance makes it the most conspieuous feature of many a woodland from Newfoundland to British Columbia.

A long aromatic rootstock bears a very short stem, from a bud on which spring one leaf and one flower-stalk. Developing together the newly-expanded leaf overarches the newly-opened flowers. As will be seen by the picture, both are in threes. This is the usual number, although sometimes there are four main divisions to the leaf, and the umbels, or clusters of flowers, may vary from two to seven; if more than four, the extra umbels spring from one or more of the primary elusters, so giving a twostoried effect.

The small, greenish-white flowers seem to be followed by either a full crop of fruit or none at all. In 1919 the bloom was copious, but little fruit was produeel; such plants, however, as had any berries bore full clusters, there being no lalf-filled ones. The berries are purplish-black or finally jet-black, rather sweet when first put in the mouth, but quickly turning bitter like quinine. They ripen late in the season, about the time the leaf turns a clear yellow.

The roots are supposed to have some medicinal value and there is a slight commereial demand for them. The official sarsaparilla, however, is from quite a different plant, the smilax of Central and South Anerica. 


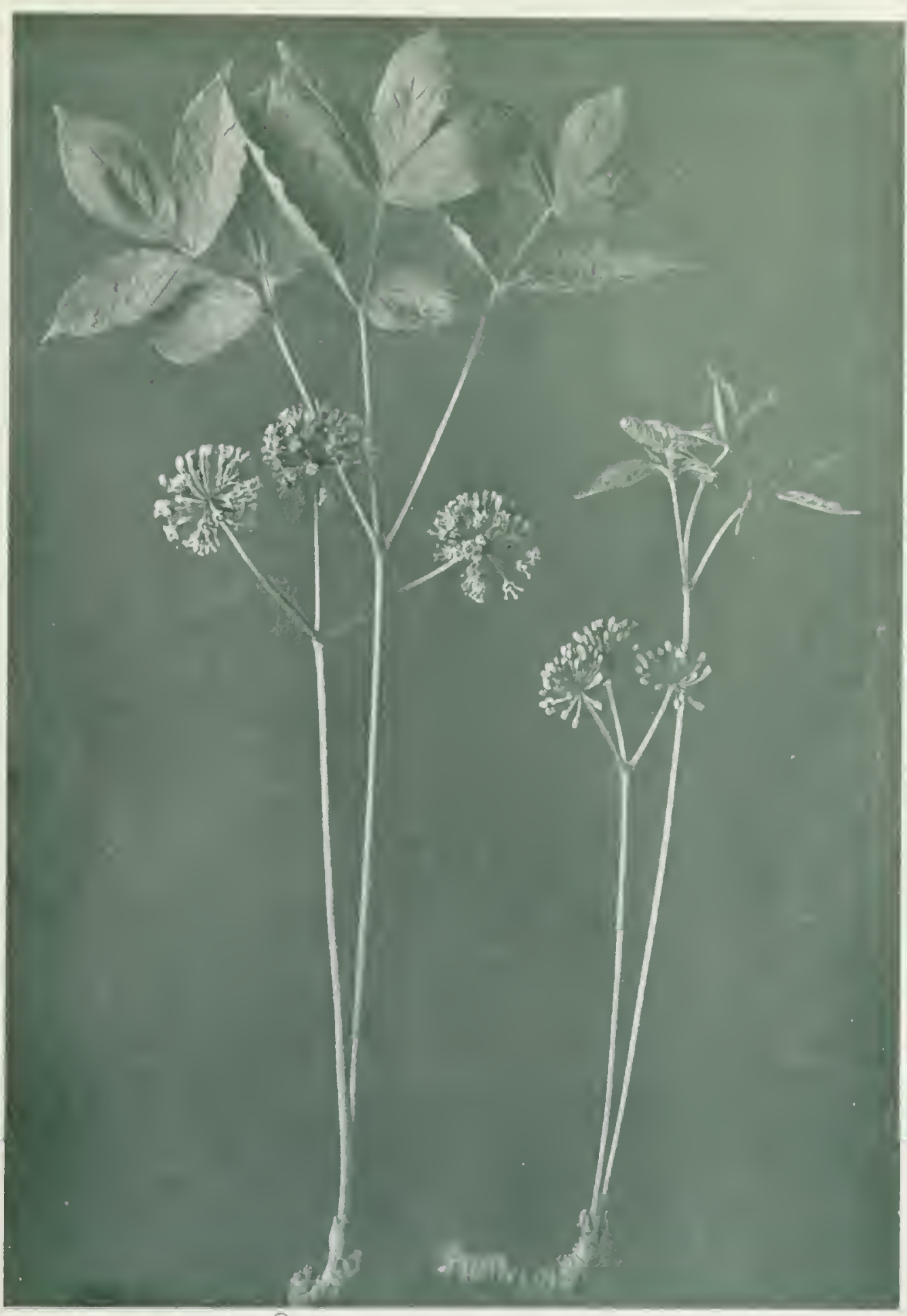

IIIII S.IRTII' |RIII 


\section{EARLY PURPLE VIOLE'T \\ I'iola nephrophylla Greene}

Violet FaMLY

Everyone knows and admires the violet, and with our arluniration is combined a wamer foeling, for it is a lovable flower with a personal, ahnost human appeal.

Out of the two hundred or more species that have been described by botanists, Canada has her full share (whether with blue, purple, white, or yellow flowers), but none is finer than this one, which grows abundantly in wet meailows and beside ponds and streams from Quebec to British Columbia. The large, long-stemmed blossoms are a true violet in color, wonderfully deep and rich if seen when "violets bathe in the wet o' the mom." If, some dewy moming, it is your privilege to come upon a little pool, bordered with these Fanly Purple Violets, then you have indeed danced upon one of the most exquisite of Nature's floral gems. You will notiee the rieh, suffused beanty of the riolet faces. You will notice the tender green of the loaves, acting, hy the contrast of their simpte freshess, as a foil to intensify the bhushing beanty of the violets which shyly peep forth above, hejewelled with wonderfut, transheent pearls of dew-elrops. The human appeal is so strong that one smiles in wondering if each violet face, perping into the expectant waters of the pool is simply greeting, or studying a waking Nature. Or hare we here simply the dhaming ranity of conserous heatuty".

A remallable fact, not generally known, is that riolets have two kinels of flowers. The serentel kind ane inconspienous green or purple buels on short, often prostrate, stems. The buels

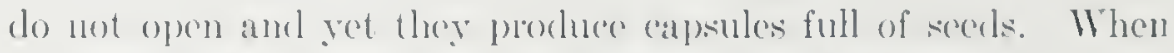
this was first notied hy botanists of the righterentle econturg, it secmed such a wonelere that they manced that partieular kinel the Miralele Violet. It has sine been fomml that with few exerpfioms all violets produce these cleistogamoms flowers, as they are (alled. Felf-fortilization in the buel is of course the explanation of the woncler. 


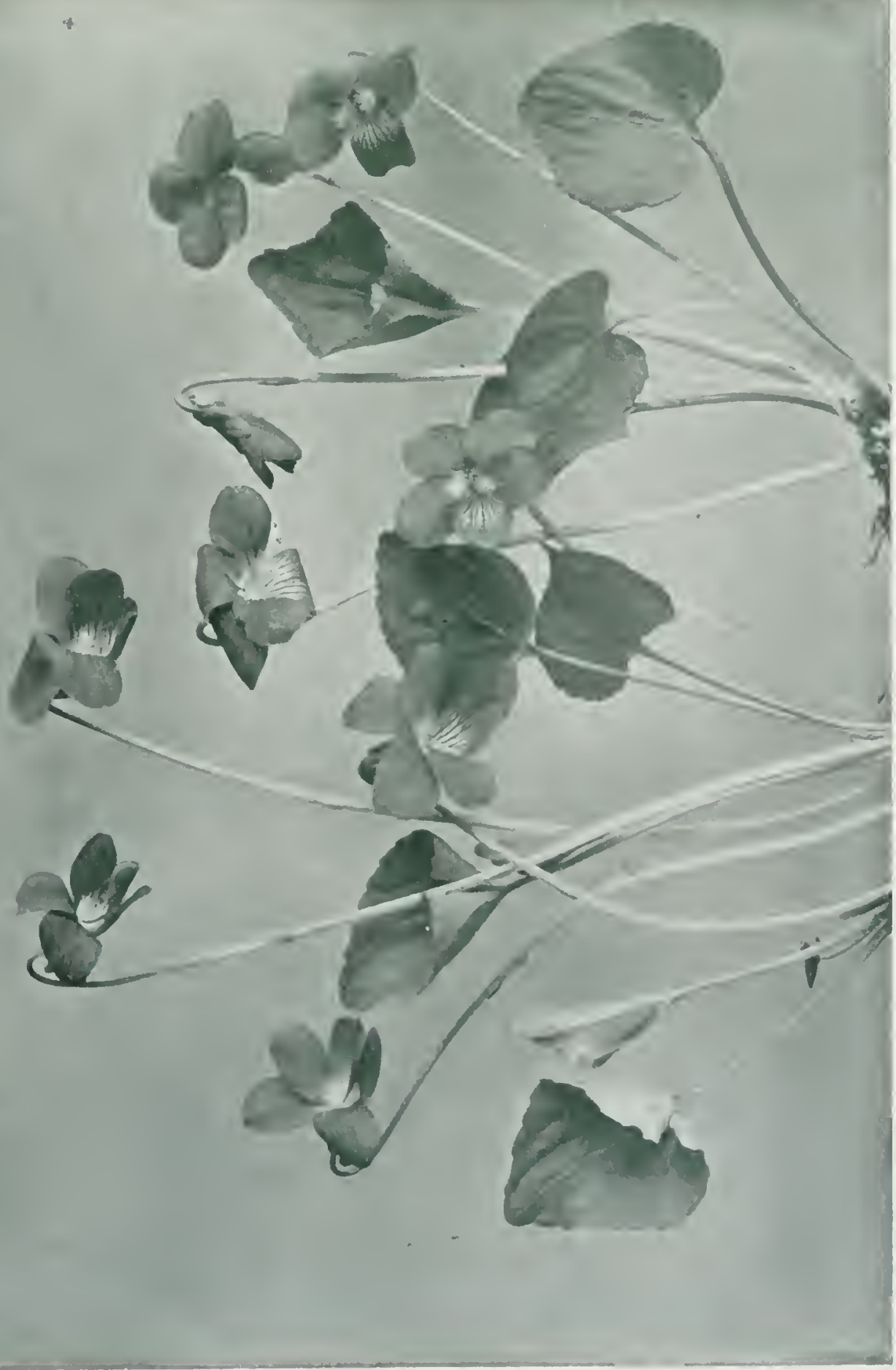




\title{
SHOOTING STAR; AMERICAN COMISLIP
}

\author{
Dodecatheon paueiflorum (D)urand) Circene \\ PRIMROSE FAMILY
}

The Shooting star is one of the most interesting and leantiful of our wild flowers, whether we consider in detail its form and color or its general effect on the June landicalpe. It elows in wet meadows and the bright blossons daneing alowe the grass are a delightful sight. Even as with Wordsworth's daffolils--
"A poet could not but be way,
In suchl a jocund ("ompluny,"

and those of us who are not poets (an also feel our lecarts fill will pleasure and clance with the sprightly shooting stars. Although one may sometimes see ten thousand at a wature. they" do mon form a solid mass of eolor but are so seattered as to lobain How offeret of lightness and grace.

The hahit of the plant is shown hy the preture. Fom llue smooth, light green leaves rise the soapes six lo fiftern inches:

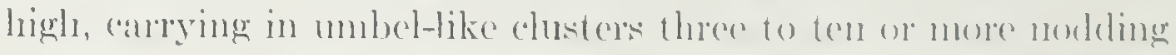
flowers. With their reflexed and twisted corollatoluse they res-

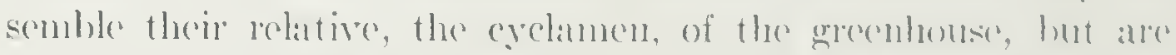
much more slender and datinty. The color is a hright purple. ahmost cerise, with the throut showing a pretty combination of

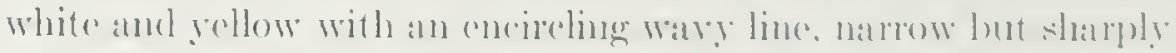

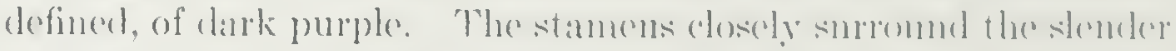
style giving a tapering point to this guame winged hossom.

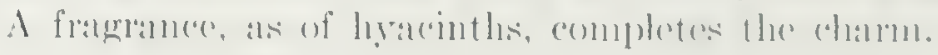




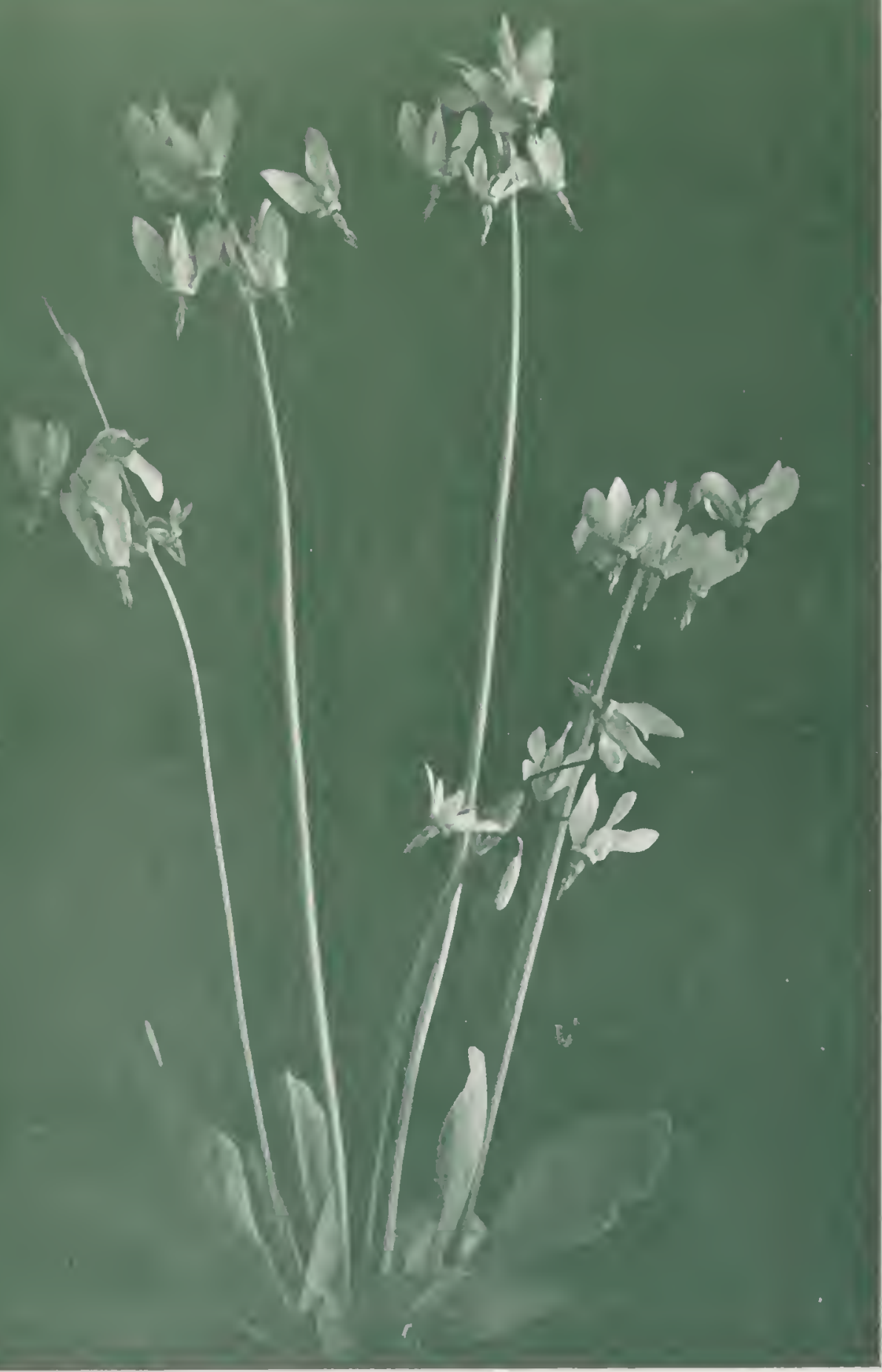

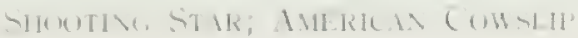




\section{PURPLE MILK VETCH \\ Astragalus hypoglottis $L$. \\ PEA FAMIIY}

This is one of the earlier and smaller of the mith vetches, of which many elifferent kinds grow in Western Cimala. Its stems are slender, rather weak, branched at the base, amel from thee to cight inches high. The flower clusters resemble alover-heark, while the leaves are reminiseent of those of the true veteh but are without the tendril. The pods are short, thick, and hairy.

The Purple Milk Veteh is common over a wide area, growing in the open or on the erlge of thickets, in a variety of soilk. It likes some noisture, and, among the grass in bow moudows, makes a thrifty growth like that shomn, ahmost matmal sime, in the pieture; hat the clecp black loam of the pration is for some reason not congenial. It may be noticel, howerer, that, where the erating of a road through such soil has in plares remored the top layer, exposing the hard, poor-looking subsoil, the Purple Milk Volde is often one of the plants that quickly and mysteriousty covers the naked earth with verelure. How do plants, strangers to the immediate neighborhood, so promptly take posicesion? To attempt a full explanation would take many pages, and be beyond the seope of this little book. One is reminded of a sentenee ly Oliver Wenclell Honnes

"Nay, there are certain patches of ground, which, having lain nextected for a time, Nature, who always has her pockets full of serels, and holes in all her pockets, has covered with lumgry plebian growtls, which fight for life with asels other, until some of them grot hroad-leaved and sucenlent, and you have a coarse regetable tapestry which Raphael would not have disclained to spreat over the foregromel of his masterpiece." 


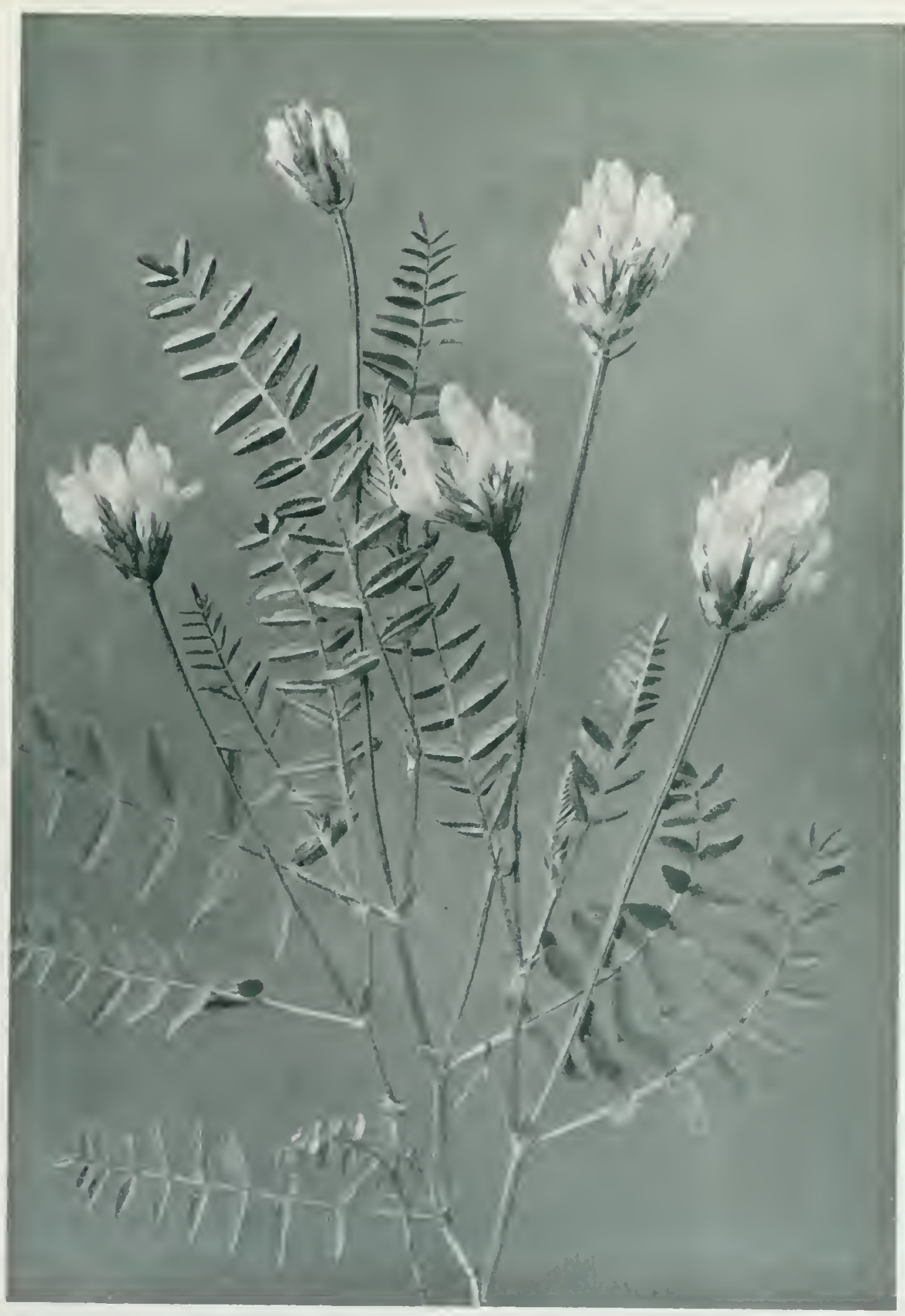

I'LRHE, MIIK VETCH 


\section{THE FOREST INYADING $\triangle$ PEAT BOG}

\section{Lutugnostic I'lunt Societics}

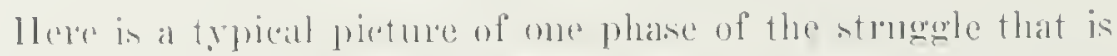
constantly woing on hetween diflerent plant soevedies. The hired mees, supported hy willows and alders. have established outposts in the hog, and the main forese of the forest are coming up to (omplete the compunest. The eommom bog plants ale still holding

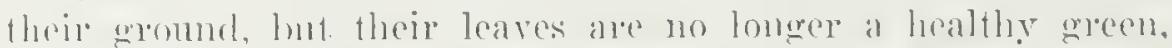

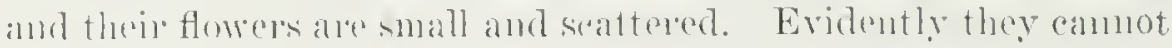
last many more grates. Behind this vietory of the forest orer the loge is a long story concisely tolel hy the late Prof. Geos. F. Atkinson of Comell Thiversity in the following palagraphs:

"Many of the porat loges were onco small ponds or lakes. The peat mos and othele plants which find shallow water a ron-

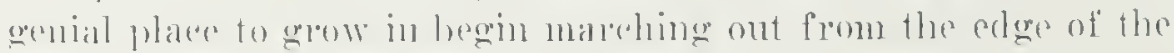

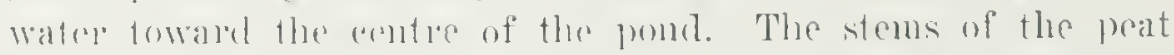

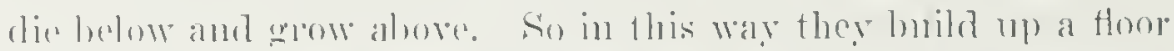
or platform in the water. The dead peat now in the water below does not thoponerhly vot. as the leaves do in the moist gromel

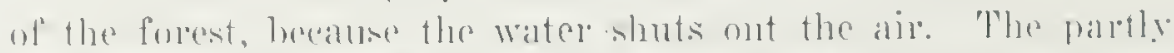
deant strms of the moss pile np) (ynite fast in making the platform,

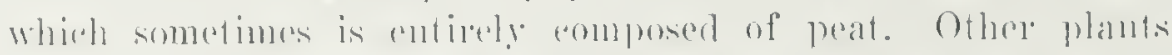
may grom alone with the peat. There dearl boclies also help to luild up this flool hemeatle.

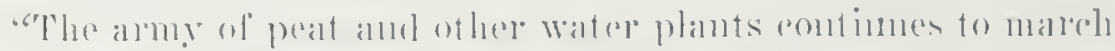

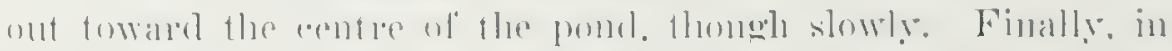

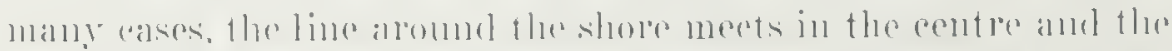

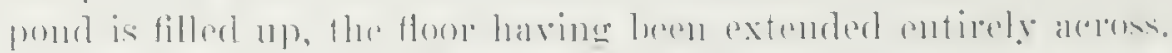

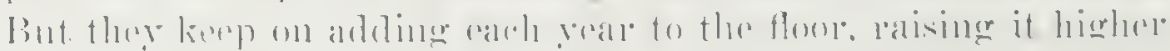

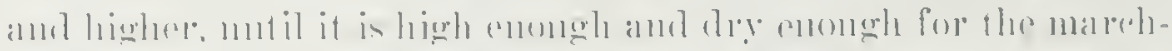

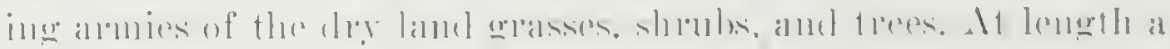

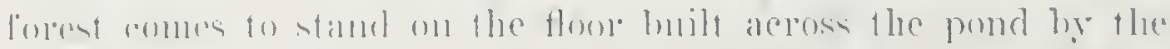

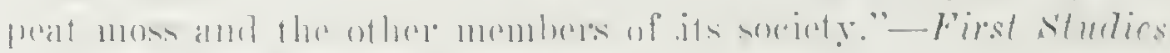

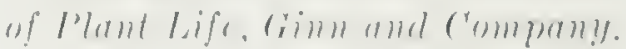




\title{
BAKED-APPLE BERRY; CLOUD-BERRY
}

\section{Rubus Chamacmorus L.}

\author{
ROSE FAMUX
}

()ne must go to a peat long in early June to find this curious litte rasplorry in lolosson. Springing from rootstocks creeping throngh the moss, the stems rise only a few inches high. They are neither wooly nor prickly as are most rasplerries, and bear two or thres simple laves instead of the usual divided ones. These leaves are plaited in the bud, and in process of expansion the underside, with firm, close ribheng, is first exposed. Slowly the ribs or veins lengthen and spreal apart, and as they do so, the laaf settles to its proper position facing the sky, so that its millions of colls, eich a tiny starch factory, may hy the energy of the sumshine produee a full disy's ontput. Sitrikingry luandsome the leaves are, rich and deep in texture and eolor.

A single flower, like a little white rose, tops each stalk. There are two kinds, as mily be seen in the pieture, where the four centre ones hear chusters of stamens, while the two tall, outside plants have flowers with pistils only. The staminate blossons soon shed their yollow (lust, then shrivel up and that is the end of them; lont the pristillate ones, if they have leceived the vitalizing touch of the pollen glains, tevelop into the plessunt berries which give the plant one of its popular names. Mamy fruits in ripening change from green through yellow to red al full maturity, but here the orelor is reversed, from green to reel, then to gellow.

When stamens and pistils anc prodneed by sepanate indivichals, the plant is said to he dioecions. This habit makes sme of crossfortilization, with its aclvantage of seeds culowerl with superior vigor and atciptalility. ()n the other hand, it is not an economical methoul as only about half the plants wan produce seods, hence most of the higher plants combine stamens and pistils in the same flower, lut so amangere thinger that cross-fertilization is 11sually

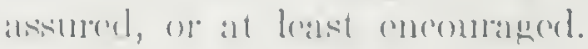




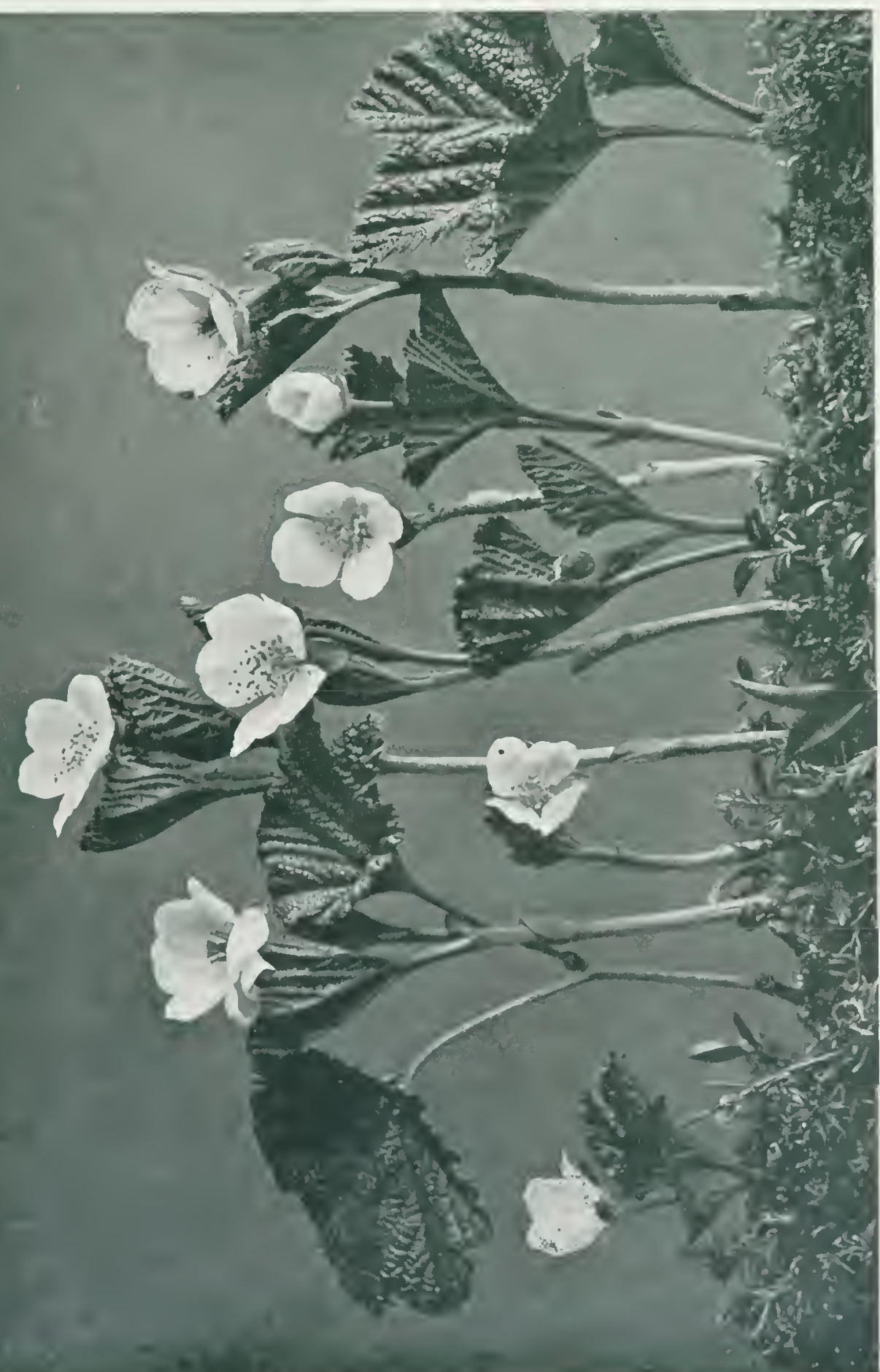




\title{
ARCTIC RASPBERRY; ARCTIC BRAMBLE
}

\author{
Rubus arcticus $L$.
}

ROSE FAMILY

Many interesting plants not elsewhere fouml grow in hogs: for conditions of life in company with peat moss are so unnsinal that only plants of special structure and hathits ean enclure or thrive. Among the commonest of these bog-lwellers are the Labrador tea, a low shub with round clusters of white flowers and thick leaves, lusty wooly underneath, and the cranlerey, with its slenter crepping stems, fimm, tiny laves and danty, pink flowers norlding an inch or two above the moss. Annong the most enrious are three "amivorous plants, the sunclew, the butterwort (whose leaves antrh and deyour insods), and the piteher-plant whose pitfalls are baited with honey above a slippery incline that senets umwary risitors to certain death helow. of the beautiful flowers might be mentioned the thereleaved Solomon's seal, the tall white hog orehis, and the pretty little ratspbrery shown natural size on the opposite mage.

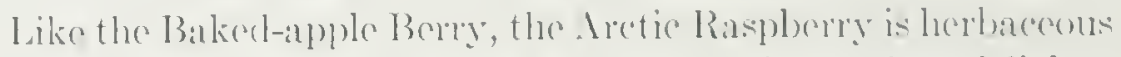
and marmed, bun more slencler and with thinner threr-foliolate leaves. The seisom of hloom is a week or ten diys later. the flower's heing pink or rose-colonerl and delightfully fratgrant. Is these atre mislatly porfert, that is, have both stamens and pistils, they anch produce a berry, hright red and of good flatror. The Aretic Raspherry likes a litthe shate and is at home in wet mosisy moods ats woll als in opern boger.

Mlthough its name sugerests the polat regions, it is sometimes

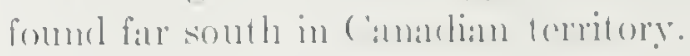




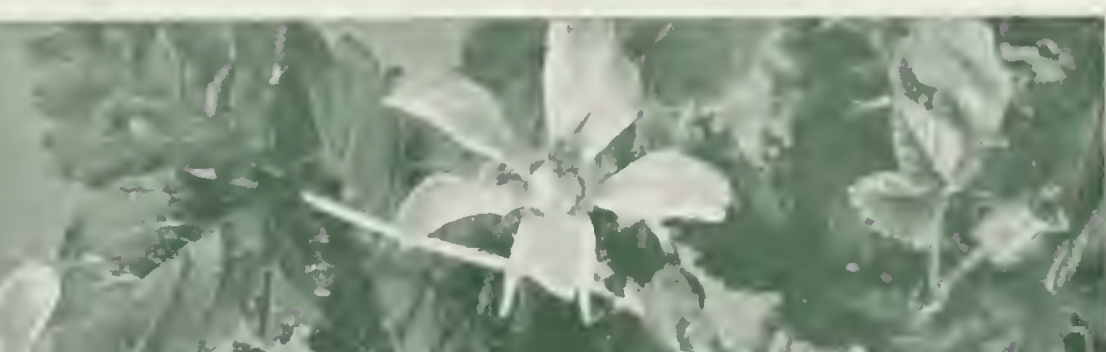

(1)

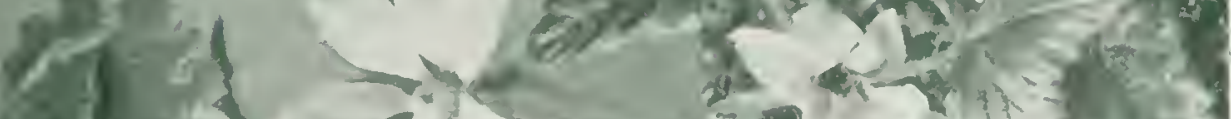
t 3 a 2 ind

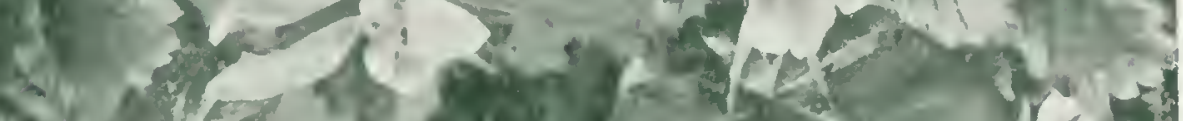

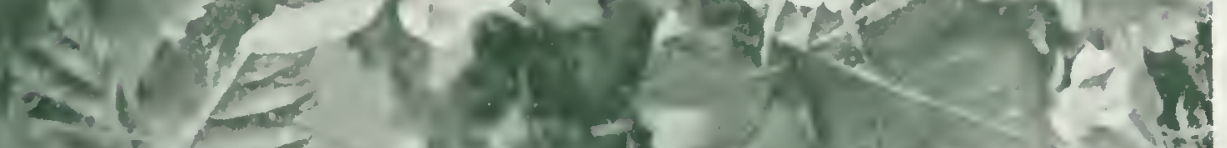
$-2 x+4$ and

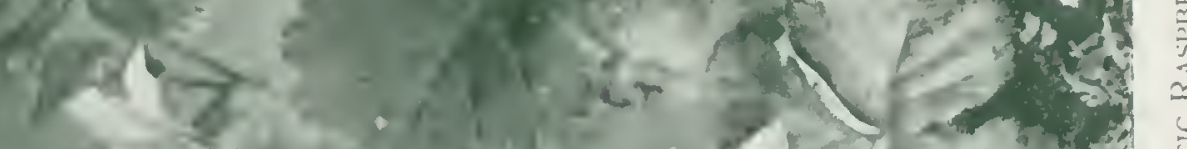

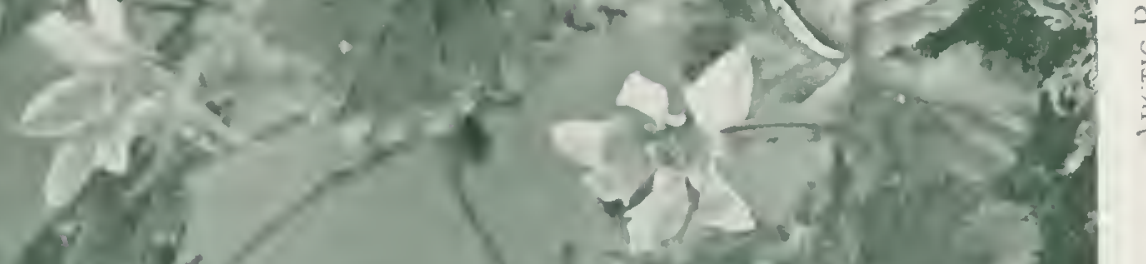
$232 \quad+130$

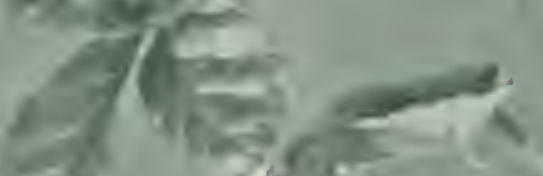




\title{
WATER ARUM; WILD CALLA
}

\author{
Calla palustris $L$.
}

ARUM FAMITY

"Y'es, though you may think me perverse, if it were proposed to me to dwell in the neighborhood of the most beautiful garden that ever human art contrived, or else of a Dismal Swamp, I should certainly decide for the su'tmp." -Thoreau.

If you feel in any measure the fascination of these so-called waste places, as did the philosopher of Walden, you will some day in your rambles come upon a colony of $1 \mathrm{~T}^{\mathrm{r}} \mathrm{ter}$ Arums. It is likely to be in a little pool in the bog or on the margin of the swamp. The dark masses of smooth, heart-shaped leares shoulel serve as identification. If in loubt, look for long, ereeping rootstocks, with white fibrous roots at the joints. If not yet satisfied, lreak a rootstalk and taste the juice, but very delieately, for it has an acrid bite. In early Summer the flowers make such experiments unnecessary, as you at once recognize a humble relation of the stately calla lily of the greenhouse.

The flowers proper are small, consisting of stamens and pistil only, and are compactly arranged around the top of the stem into a fleshy spike, called the spadix. Below this is a thiek, pointed bract, the spathe, white on the inner surface, greenish on the outside. This snowy banner behinel the inconspicuous spike serves to attract insects, who uneonscionsly aid in fertilization as they rawl over the flowers and pass from plant to plant. By late Summer the spadix has developed into a large, knotty head of bright red berries, containing hard, smooth seeds surrounded by a jelly-like pulp). 

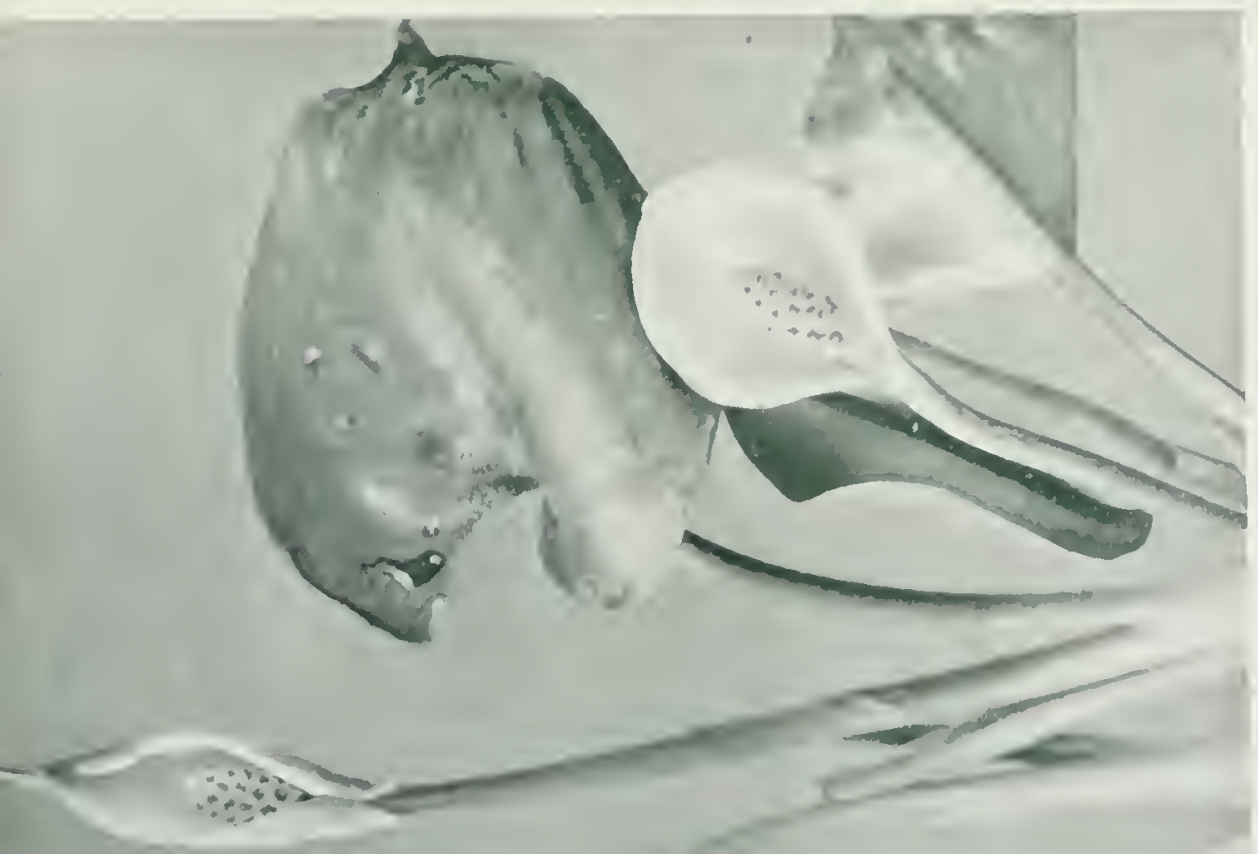

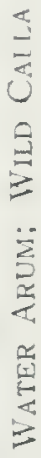

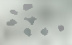

.

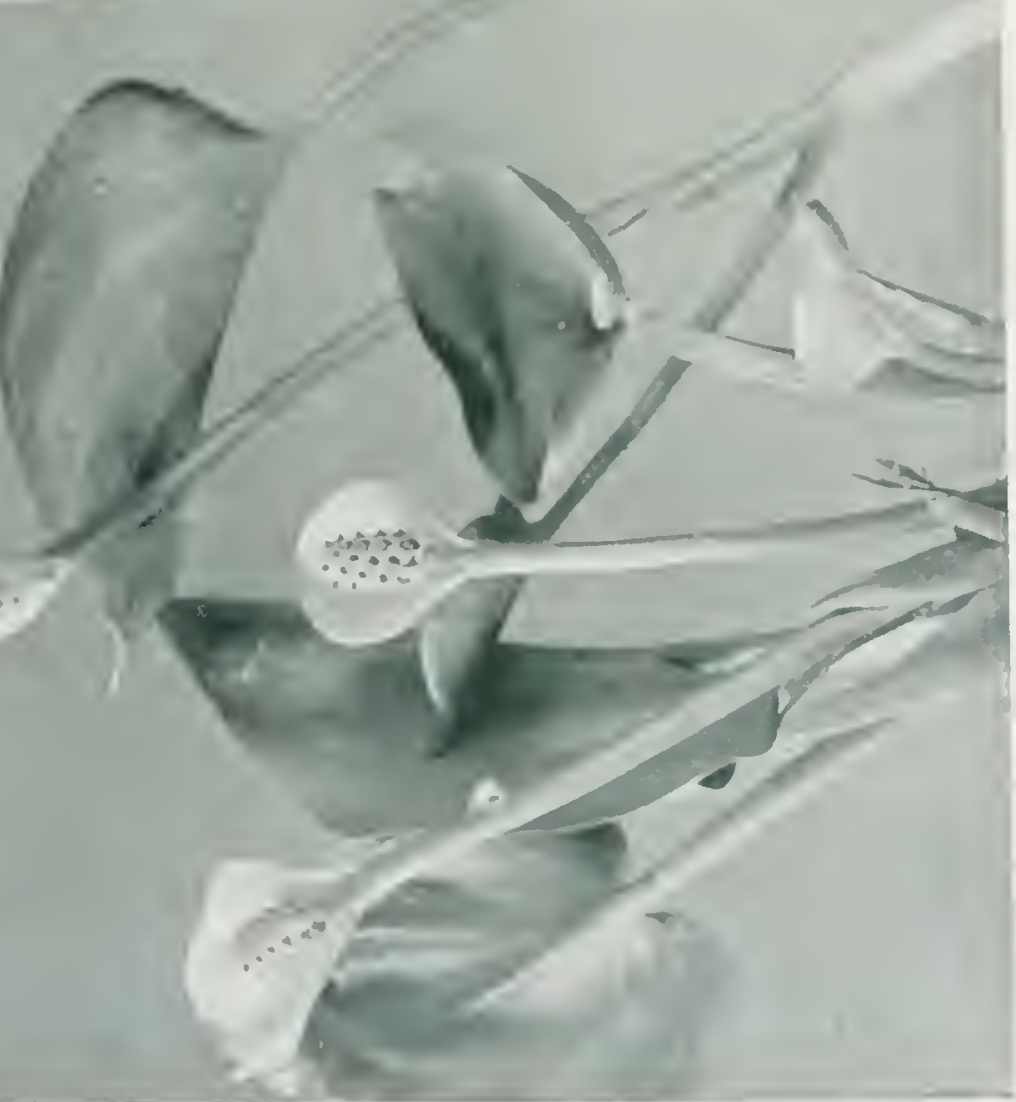




\section{SILVER-WEED; SILVER-FEATHER}

\section{Potentilla Anserina $L$. \\ Rose FasiLy}

The Silver-weed has a cheerful and active disposition, readily aclapting itself to a variety of conditions, and quickly grasping opportunities for advancing its fortunes. Preferring wet ground, yet making the most of dry, it has oceupied so much territory that its neat silver-green uniform is well known from Newfoundland and New Jersey to Alaska and California. While its behavior at times is such as to class it with the weeds, it certainly is not pernicious.

Silver-feather is a better name because of its plume-like leaves, silvered beneath by long, silky hairs and usually green on top. Sometimes, however, the upper surface has also a thin, silky covering. This variation with its cause is niccly shown hy two patches besicle the house of the writer. One is close to the founclation on the south side in poor soil, exposed to full sunlight, and the leaves are gray green. The other is on the west side in rich loam, getting no sun until after eleven o'elock, and here the upper surface is bright green.

The yellow flowers are produed over a long seitson, as they spring from the axils of small leaves on the strawherry-like rumers sent out in profusion. These runners are usually from one to three foet long, ancl from then new plants start every few inches. A mat of vegetation is soon formed. In producing and directing their runners, the plants exhibit something very like intelligence, as the following instance will show. On the shore of a little liake in 1919 grew a vigorous Silver-weed. The dry season fowered the water until a strip of sandy bottom cight feot wide was exposed. 'Tle plant was chowded behind and on either side hy competing neighbors, but in front laty this land of promise, so, with ronecntrated energy, a single runnel was pushed out straight towarks it. By the twenty-fometh of August an alvanee of over five feet had bern made, and eighteen young plants established on the line of mared were aiding the parent in its forward novement. 


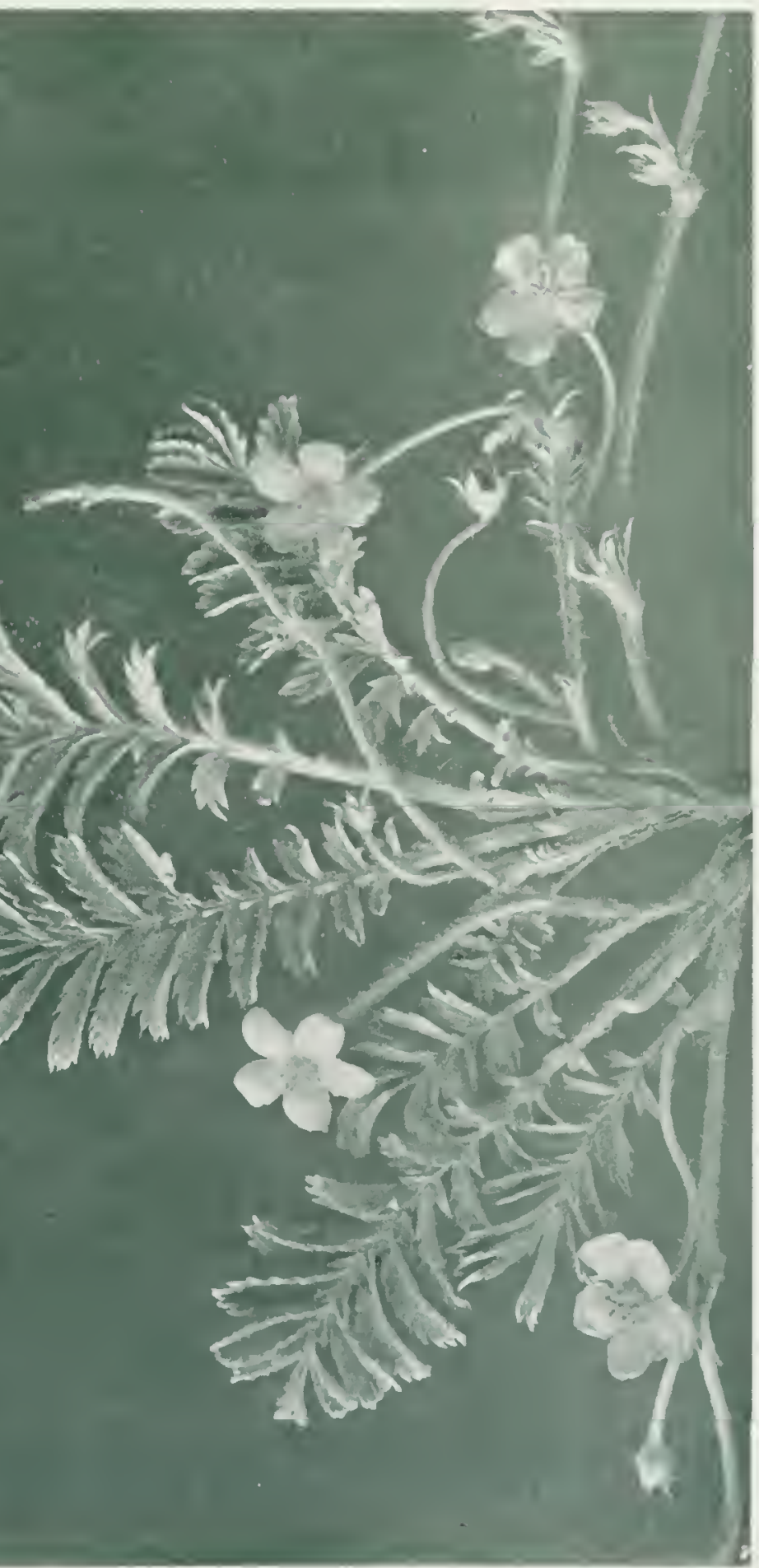




\section{ROUND-LEAVED ORCHIS}

\section{Orchis rotundifolia Pursh}

Orchid Family

Although not one of our rarest or showiest orchids, this one is pretty enough, and in most districts uncommon enough, to make its discovery a happy event to the lover of flowers. Some years ago, in October, I found a few dried stems with empty seed cases at the top and a withered leaf at the base of each, and recognized an old acquaintance not met with for fifteen years. My eagerness took me back too early the next Jume, but on a second visit, the two or three dozen plants were in full bloom. This small colony has flourished and spread along the little waterway, and last Summer several hundred flower-spikes were produced-a sight worth going far to see, and a natural garden worth preserving.

The Round-leaved Orehis lives in rich, moist wooks, often where the ground is covered with moss, from which, leaving its single leaf behind, the flowers rise in erisp, glistening punity to a height of about six inches. They are white, delicately tinted pink with a suggestion of n11aure. The upper sepal and two petals form a hood, and under it stands the column, a structure peculiar to the orchicl family, in which are combined the organs corresponding to stanens anch pistil in other flowers. On either siche are wing-like sepals, while in front, the third petal spreach out into a purple-spotted lip or apron, and below is a curved tube containing nectar. The hood protects the colmmn, the esscntial pirt of the flower, the lip is the landing stage for the winged guest, who finching in front of him the opening into the nectary, thrusts in his tongue, thus bringing his head against the athesive ends of the two pollen masses. When he fies away to the next flower he of course carries the pollen along.

The wonderful intercelationship in form and service that exists betweon flowers and inseets, suggestal in the above description, is nowhere carried to such a specialized degree as in the orchich family. 


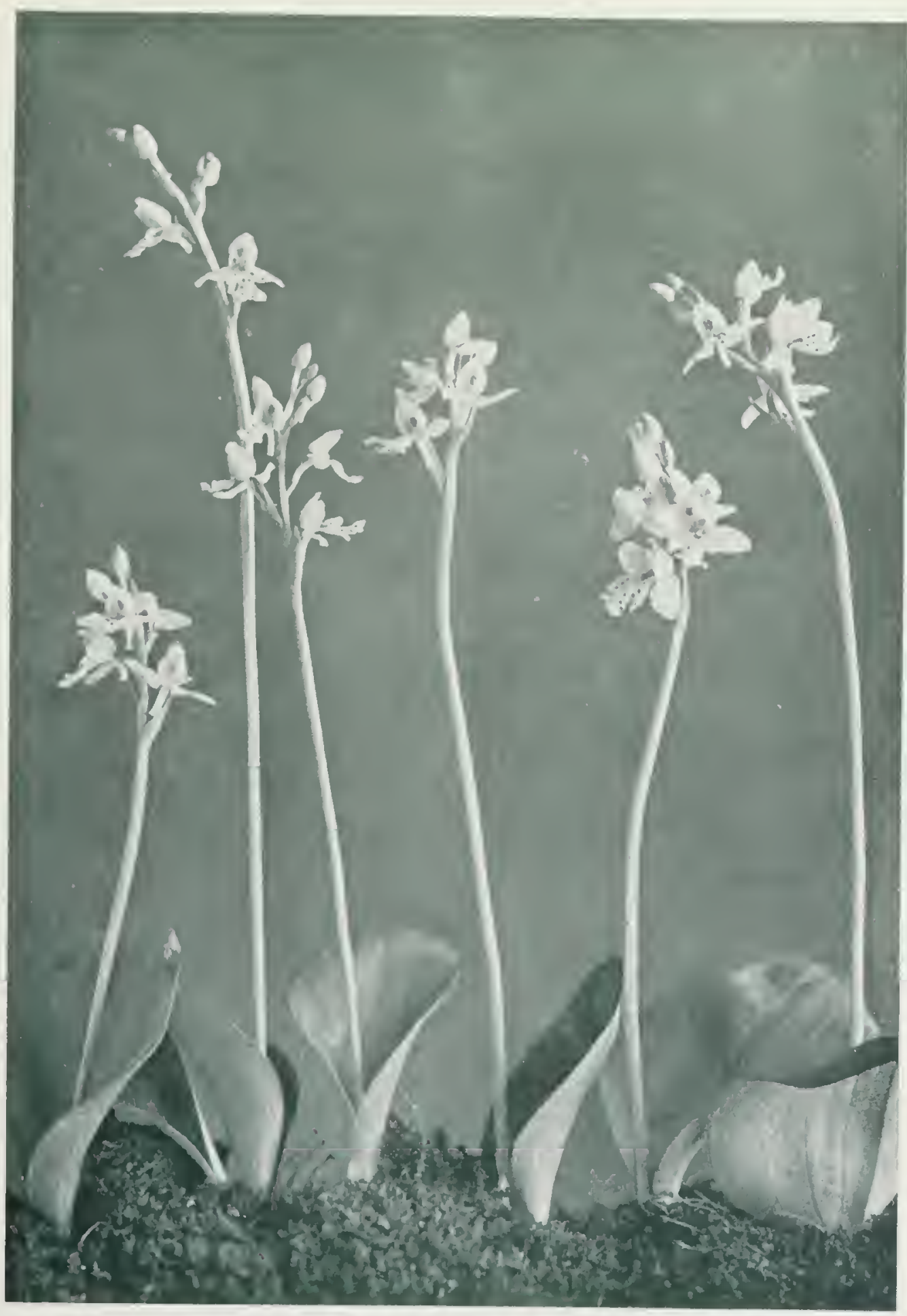

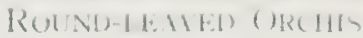




\section{BLLE BESRIATONGUE}

\section{Prutstemon procerus Dougl.}

FH:WORT FAMIL

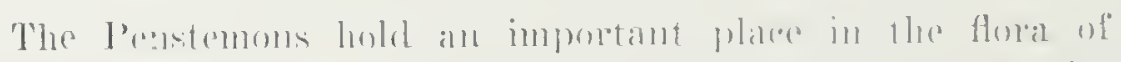

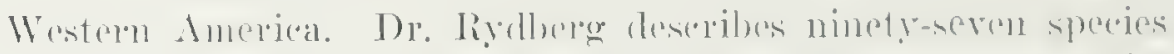

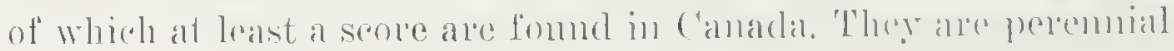
hereles fomel for the most part on dry plains and hillsides. Theire

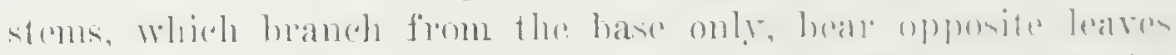

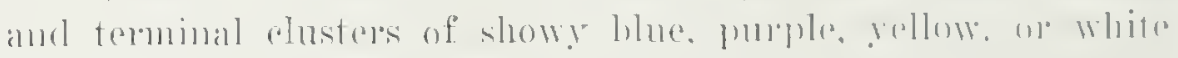

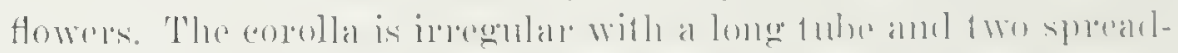

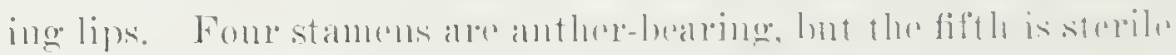

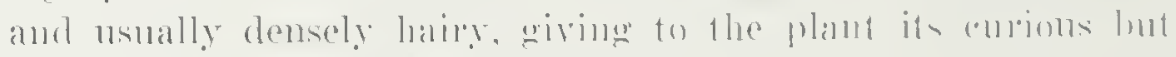

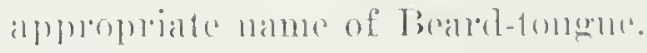

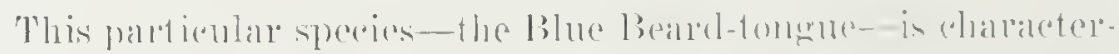

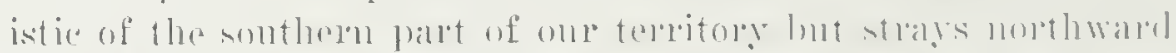

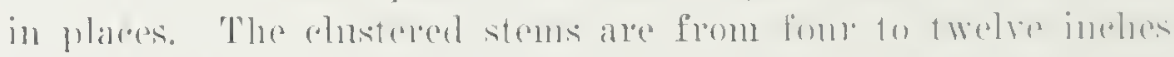

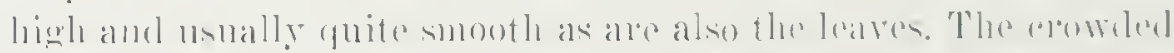

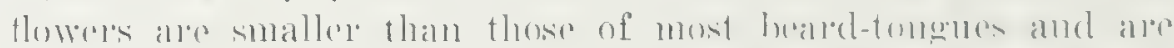

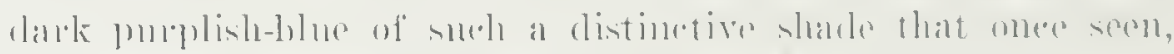

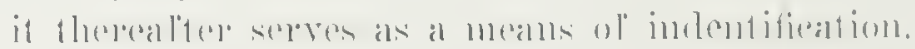

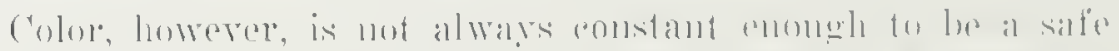

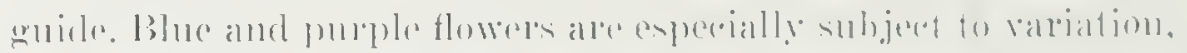

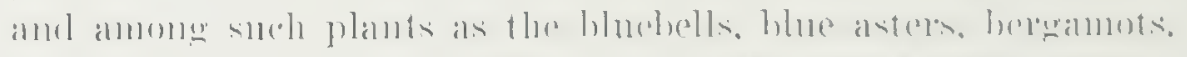

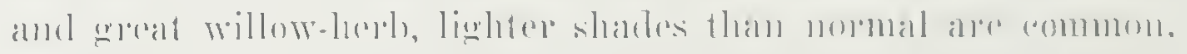

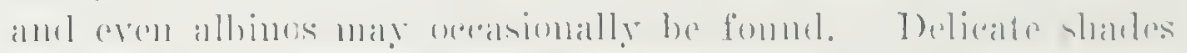

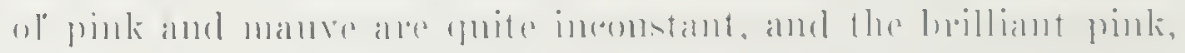

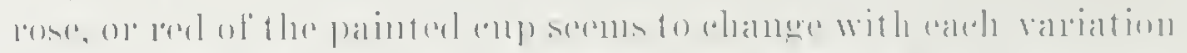

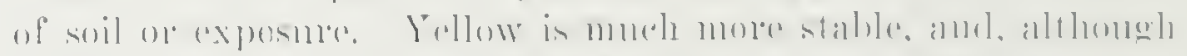

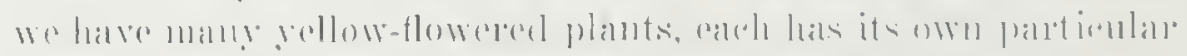

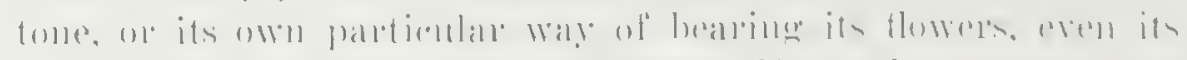

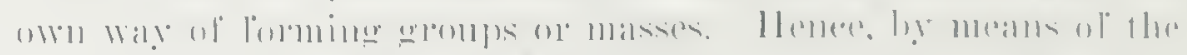

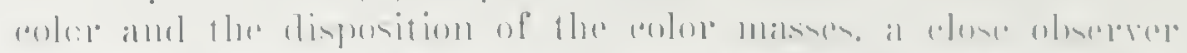

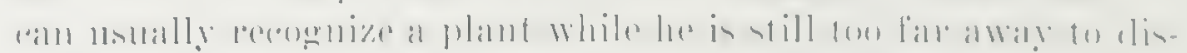

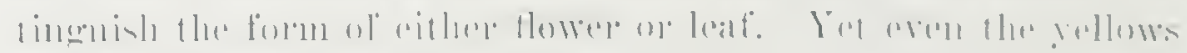

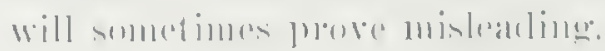




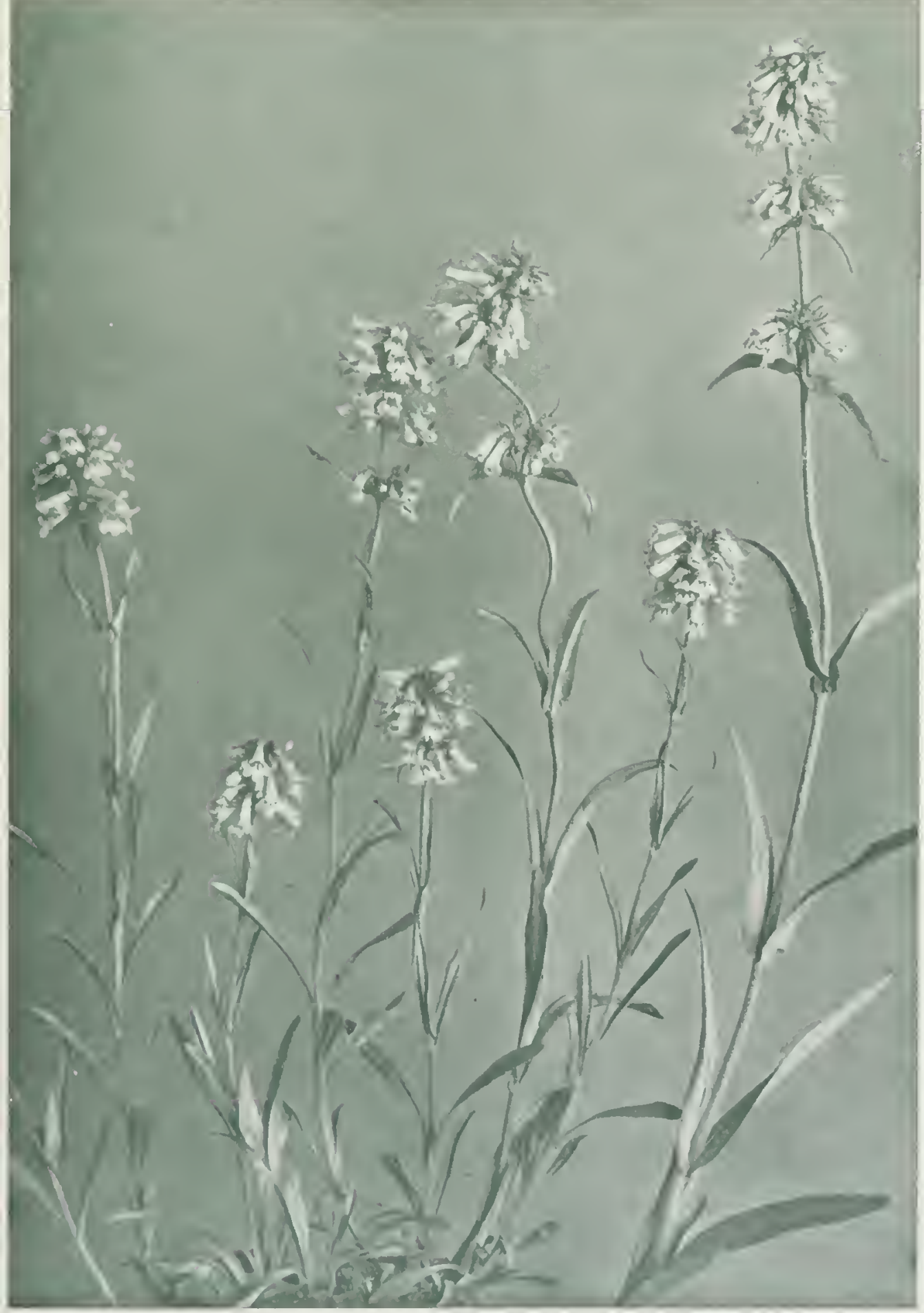

BH I [3F.IRT) T(NG\% 


\section{BIRD'S-EYE OR MEALY PRIMROSE}

\section{Primula farinosa $L$.}

\section{Primrose Family}

The primrose, like the violet, has ever been a favorite with the poets. Shakespeare, Burns, Wordsworth, and many others have sung its praises. One who has rambled in the woods and along the lanes and hedgerows of Fingland in early Spring can understand what a large place the primrose holds in the life and literature of the people.

But the Birl's-eye Primrose, although widely distributed and often abundant, will never take the place in Canada that its yellow namesake holds in the Old Land. It is too shy, and so massertive in color and habit that it is often walked over without being seen. It grows in wet meadows and is usually half hidden anong the grass. Of this Primrose, as of the walking-fern, it may be said that no one ever found it, unless it was first in his heart. Still, observation can be assisted to locate it. For instance, the Shooting Star and this Primrose frequently grow together, so that the gaudy flowers of the former may readily help one to find its pretty but retiring relative.*

Ah! here are a few, on tip-toe, as it were, to peep over the surrounding damp sedge. Pluck one and notice the corolla, pale lilac in color, with a yellow eye. And the leaves! Notice how they are tufted at the roots, of a pale green color on the upper side, and covered on the under side, with a fine white down which gives a white mealy effect. This white down also creeps up to cover the flower-stem which is from four to fifteen inches high. The whole color effect is in harmony with the surroundings. whitst yet leaving the flower with a modest distinction.

"It shoukl be said that while their perionls of bloom overl yp, the shooting Star opous first by a wook or two. 


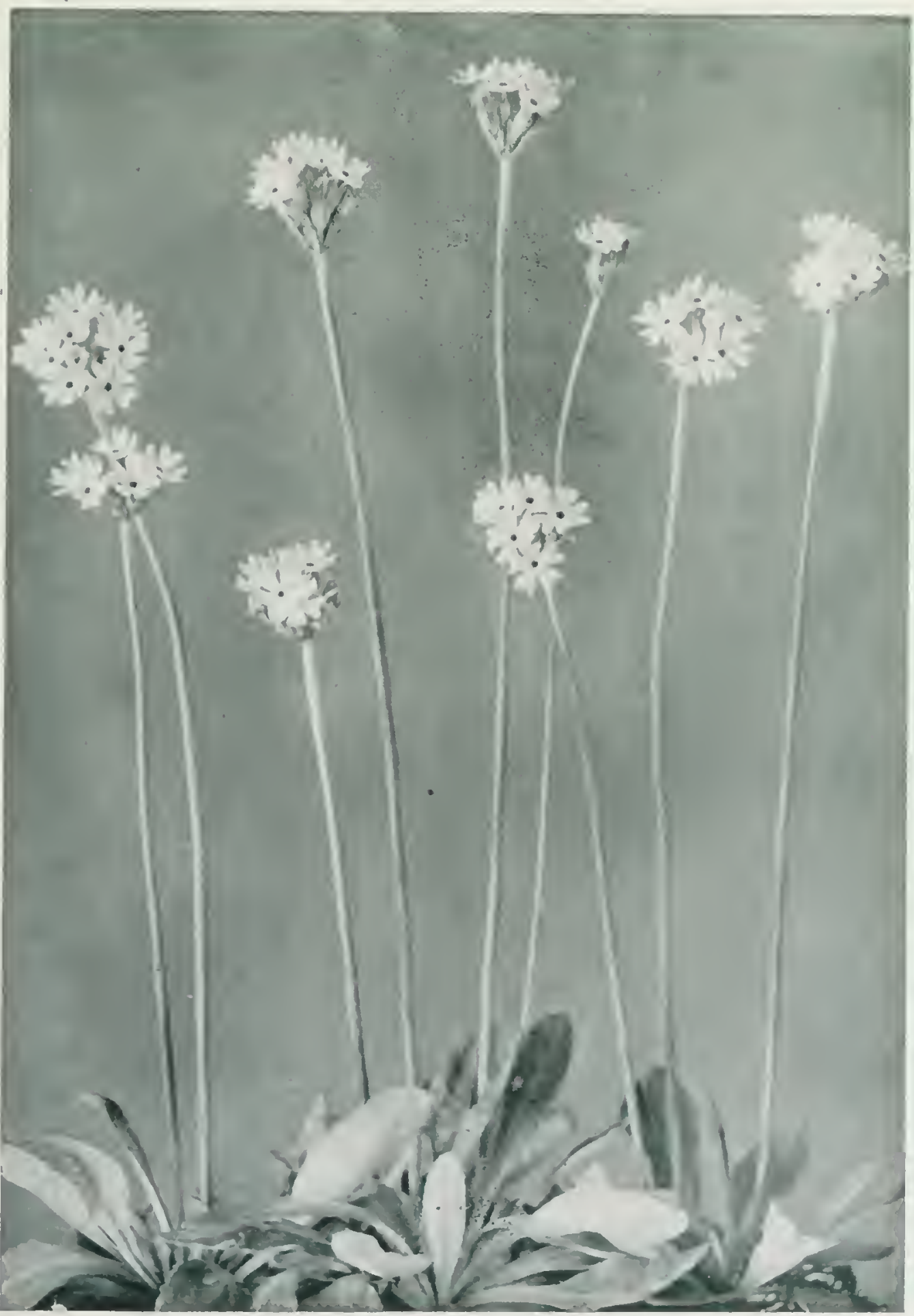

BIRW'S-FYT: OR MIF.ALY I'RIMIROSL: 


\section{MARSH RACINORT}

\section{Semroio T'ulustris (L.) Mook.}

'THATIE FAMH.Y

The Nareh Ragwort belonge to the erreat. family of the Compositar which mumbers ovele ten thousand speeies in all parts of the earth. In Western Canada, begiming in early Suring with the sweet coltsfoot, the fambly increases in importanee as the season advanees mutil late in Summer the sumfloweds, dalisis. asters, gotdenerls, and other members of the family quite dominate the floral world.

The flowel's differ from those of othere families being bontur many towether in a eompact head smommeded hy lowats. In this subdivision of the family the Howers ane of two kinds. the disk florets. small, tubulate, and croweted, in the rentre and the

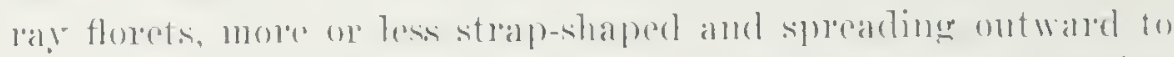

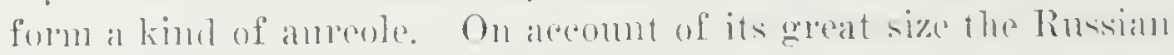
smoflower is a groot composite to study first.

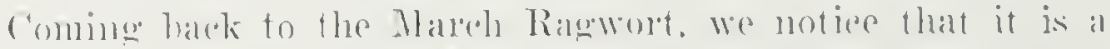

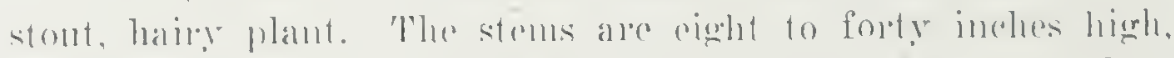
the bigere ones as thick as a hroom handle. All are hollow.

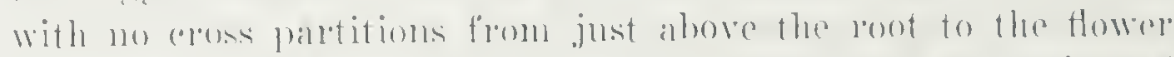

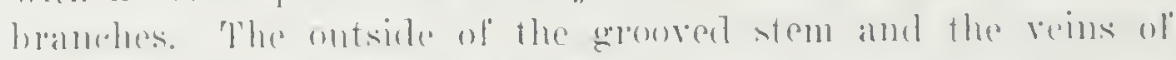

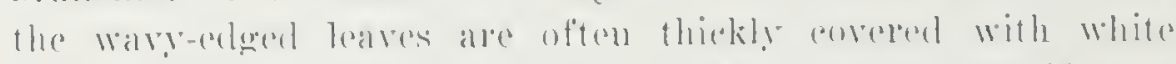

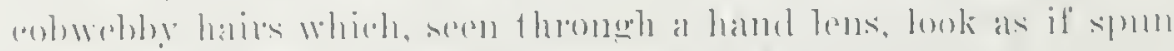

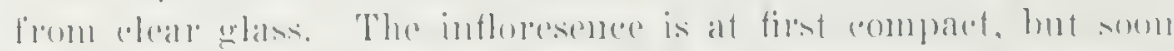

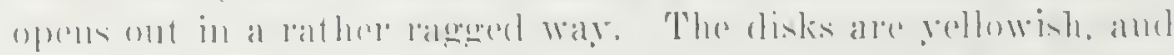

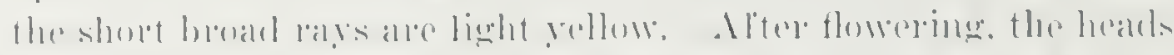

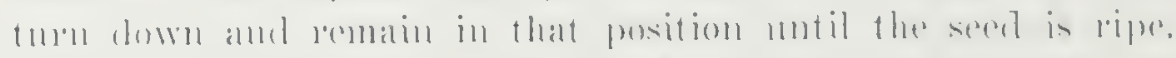

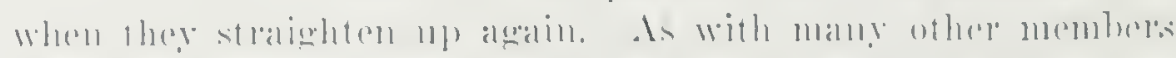

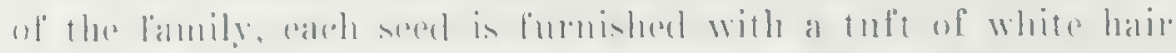

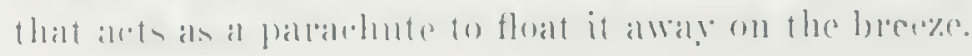




\section{ZONES OF VEGETATION AROUND A POND}

\section{Marsh Raguort forming the first belt thirty feet wide}

Such a pond as this is a good place to study plant socictics, both congenial and antagonistic. Some plants live together in peace, sharing space, food, and water, and in various ways being mutually helpful; others wage war on their neighbors, the success of one bringing disaster to competitors. The character of the season has a large share in determining with whom victory shall rest.

The year 1919, or perhaps the Fall of 1918, secmerl to faror the Marsh Ragwort which is usually a Winter amnual. In many places it was more in evidenee than usual, but nowhere have I seen a more complete triumph over competing regetation than it won around this particular pond. In the zone suited to it, every foot of space was oceupied to the exclusion of all else. Behind the ragworts was a fairly solid belt of the great bulrush. Back of this were coarse grasses and sedges, among which, however, the northern green orchis, the skulleap, mint, knotweed. and other plants were thriving. On still higher ground the willows cominated, as did the poplars on the low ridge in the background.

By mid-dugust the water was gone and the mud heginning to dry and crack. The portion of the pond bottom that show: as a mud bar in the picture was densely carpeted with young ragworts six inches high. In the reeper parts, where the water remained longest, and among the clearl stems of the parent plants. seedlings were breaking gromel in comtless numbers, henee the ragworts bich fair to repeat their triumph next year. We may wish them goor luek, for they stay in their own place, do not mareh up on to higher lanel to choke out the farmer's crops, and in Jume transform their portion of the landscape into a veritable "Fielel of the c 'loth of Cold." 


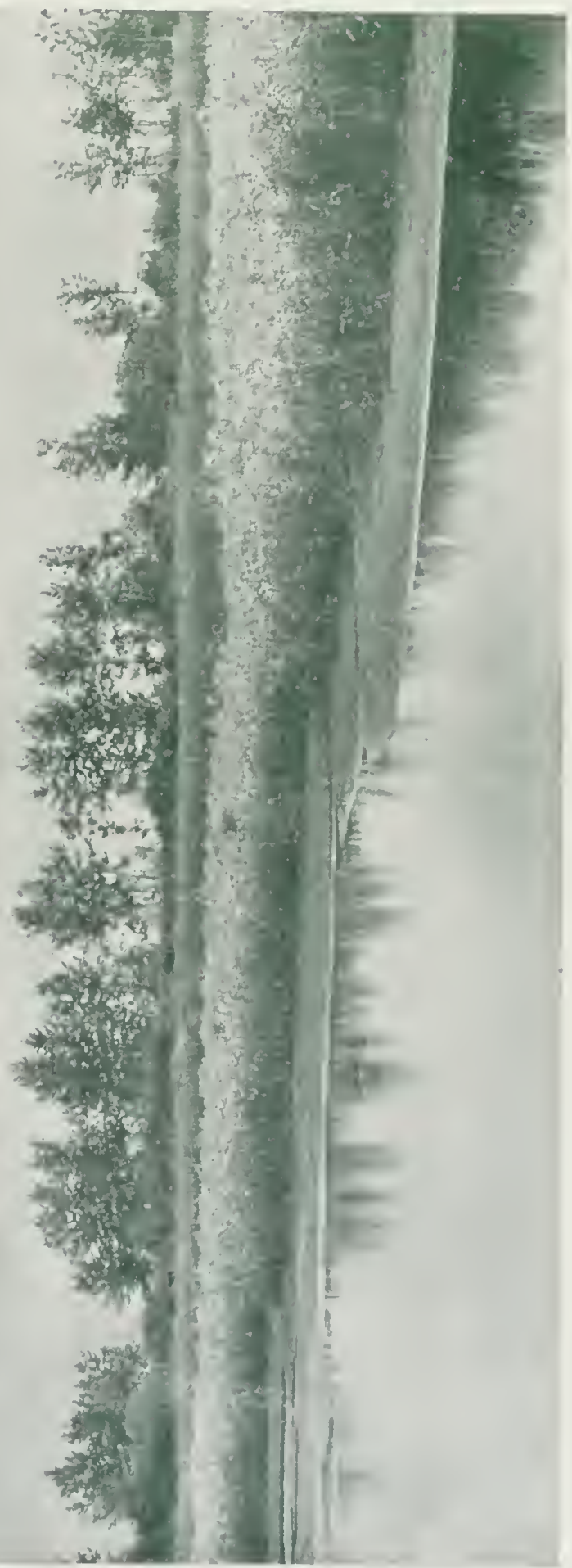




\section{TALL LUNGWORT; BLUEBELLS \\ Mertensia paniculuta (At.) C. Don \\ BORAGE FAMILT}

Although many members of the Borage family are rough, hairy herbs of weedy aspect; others are of marked heauty and refinement. Among the latter might be mentioned the valnillascented heliotrope of the grecnhouses, and the forget-me-not which beautifies alike loncly momtain streams and formal city gardens. But the finest of the family and perhaps the loveliest of alt bhe wild flowers in Canada is the Virginian comslip (.Mertensia virginica). It, however, is found only in Fouthern ()ntalio and is rare even there, while this western Mertensia is widely chistributed and abundant, no other blue flower of carty summore being so conspicuous in many districts.

The pieture shows the plint much recheed in size, as the stens grow from one to three feet high. They hear open chusters of drooping flowers which are pink when in burl, tuming riels blue as they open. The dark green kaves, especially those at the base of the stem, are strongly and handsomely reined.

In open meatows, where it sometimes grows, this lamgwort is rather st iff and quite hairy; in shade and alongstreann it beromes smoother, talker, and more graceful; while among bushes on mountain slopes, high onough to be froquently bitherl in mist, it may be seen in such perfortion as to rival its lorely aistern relative. 


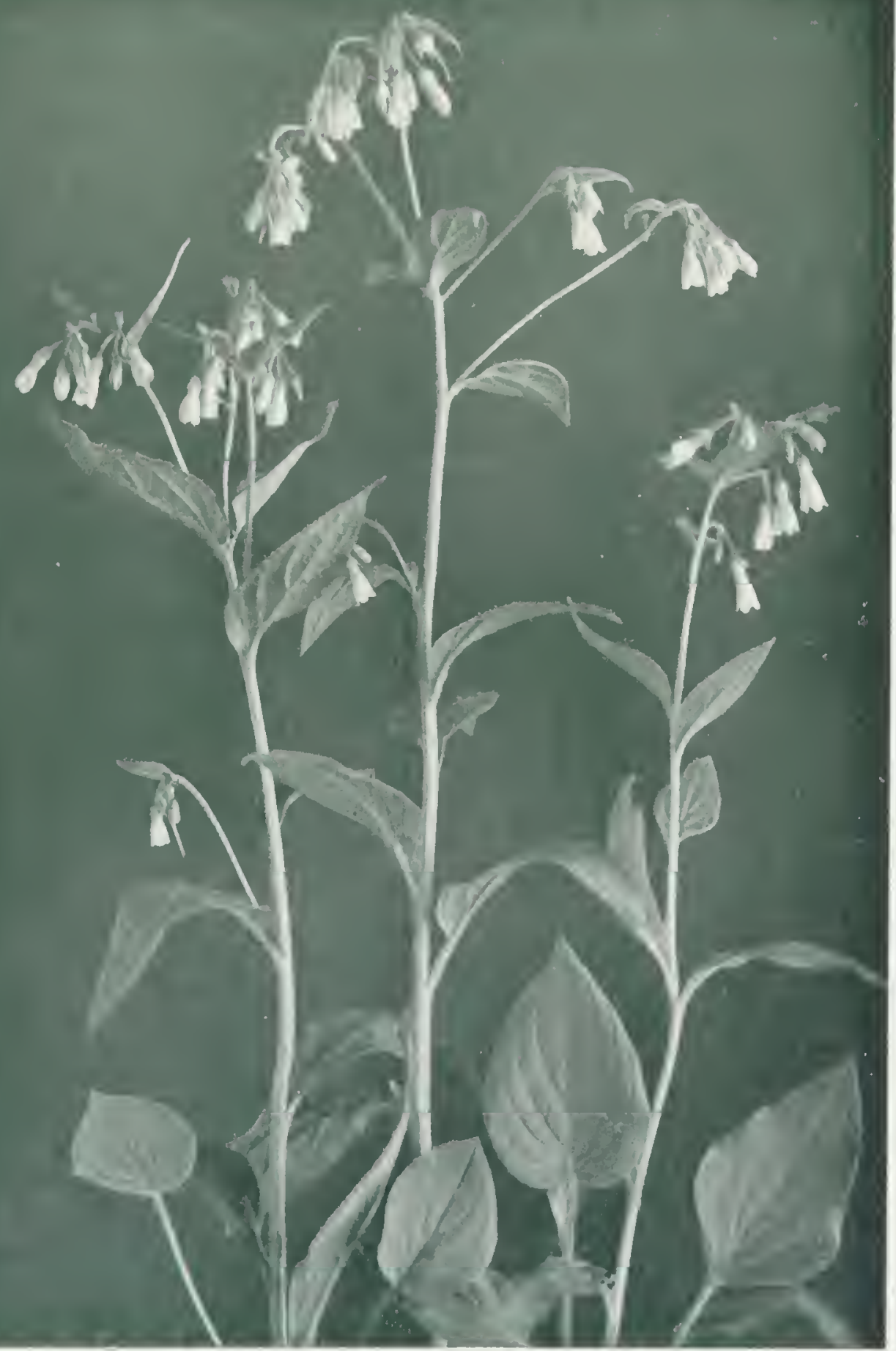

TALL LLiNGORT; BLteBells 


\section{YELLOW LADY'S SLIPPER \\ Cypripedium parviflorum sualisb. \\ Orchid Fanily}

The orchicls, the aristocrats of the floral world, form a large family, with family seat, as it were, in the tropics and scions in almost all parts of the earth. Some of them, cspecially those that grow as airplants on tl bark of trees in hot, moist forest., produce flowers weird and fantastic, or marvelously beatutiful, beyond imagination. Thousands of species have been found by collectors who risked, and sonetimes lost, their lives in the search. Sent home to Europe or Ameriea, these dorniant plants have been purchased by orchicl enthusiasts in whose hothouses under skilful and devoted care they bloom again in wondrous diversity of form and color.

Our Canadian orchids are all land plants, and while a number have small, inconspicuous flowers, interesting chicfly because of their structure and family relationship, a dozen or so ane of such beauty and clistinction that they would be noticed in any company. Of such is the Yellow Lady's slipper pietured here.

The inflated lip or slipper is deep yellow, and the other parts are yellowish-green, often striped or shated with dirk purple. The long, natrow side petals are usually twisted or curled, enlatncing the charm of these strange flowers, which are so poised that in a bresere they secm animate, expectant, ready for cager flight.

This orchicl, growing in open woods and thickets and blooming in June, wats at one time comparatively common in many parts of Canada, but advandeing divilization is chestructive of native life, and they are beconing raler cach year. The remaining ones shoukl he preserved as far as possible or this splendiel plant is likely to be extermininterl. 


\title{
TWIN-FLOWER
}

\section{Linnaca borealis var. americana Rehder}

\author{
HonerstTekla Fanhar
}

"He saw benerth dim aisles, in odorous beds,

The slight linna'a hang its lwin-born herwh,

ind blessed the momument of the man of floneress,

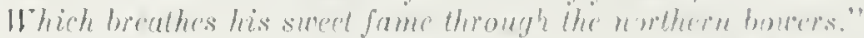

- Emrisun.

This dainty, trailing vine with small, evergreen leares and fragrant, pink flowers was a favorite of Limbares, the great swedish botanist of the righteonth contury, in whose homor it is named.

In Canada it ocenrs from ocean to ocean and from the tretic to the international bomndary. It is likely to be fomel in woods surrounding bogs, on the shady sirle of lavines, and in any cool, moist forest. It is especially at hone in the mountains. andel many reaters will rementher how delightfully some of the wootland trails at Banff, Lake lonise, and Jasper alde bordered with its "oldorous beds." spring comes first to the valleys and travels slowly ep the mountain sides, so if the visitor le too late for it at the lowere altitudes he need only do a little elimbing. Late in July on a monmtain slope at datsper l'ark l siaw, not patches only, but a vast, (ontinuous canpet stretching away for miles. As we went up though the loxgepole pines, the first plants med with wore in secel; a fow hunderel feot higher some hedated flowers were seren; still higher, bloom was at its best, tinting the flowe

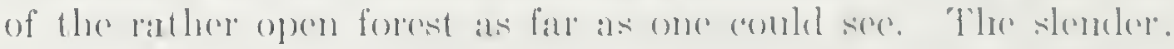

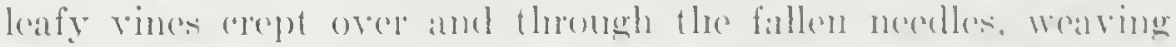

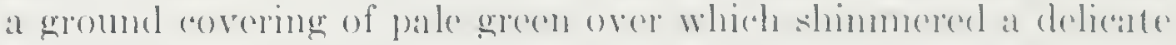

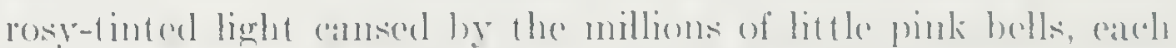

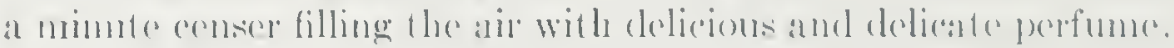

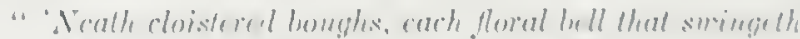

fled lolls its perfume on the prassing anr,

Halos sizbluth in the fichls, and arer ringeth

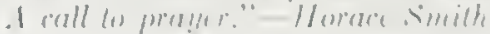




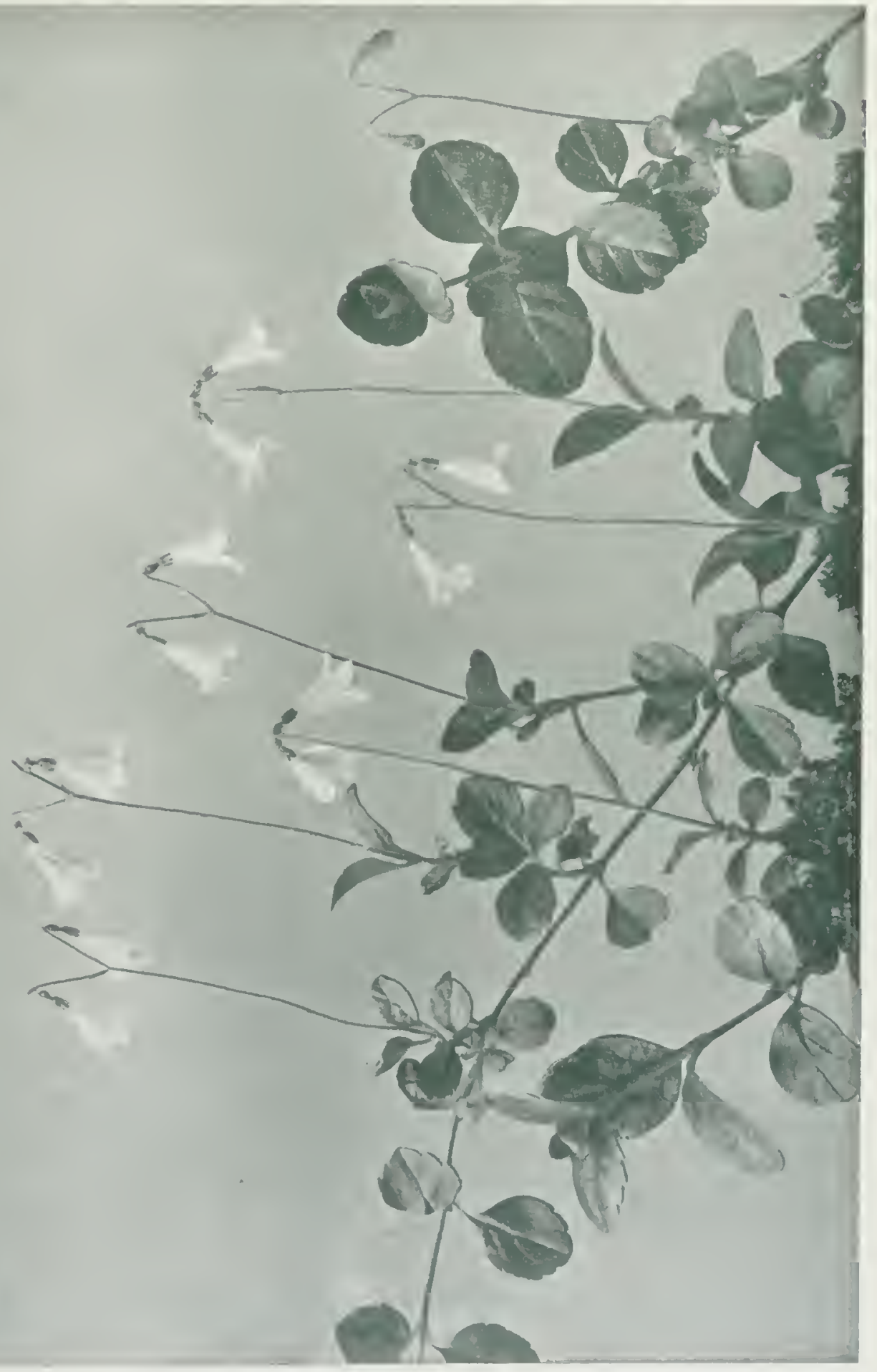




\section{BUNCHBERRY; DWARF CORNEL}

\section{Cornus canadensis $L$.}

DOGWOOD FAMLY

The Dogwood family is represented in Camada by many handsome shrubs and trees. The most famous of the latter. group are the two flowering dogwoods, one species found in Southern Ontario and the other on the Pacific Coast. These trees, when covered in Spring with clouds of large white blossoms and in Autumn with brilliant foliage and bright red berries, are the most splendid ormaments of the woollands where they oceur. Owing to their limited range, however, these flowering dogwoods are known to comparatively few Canadians.

But the Dwarf Cornel, the pigmy of the family, is common in cool, damp woods from coast to coust. Its floral arrangement is like that of its two big relatives. The true flowers are small and greenish, in a compact head surrounled by four white, petallike bracts. Wach flower-head springs from the eentre of a whorl of broad, strongly-ribbed leares, borne at the smmmit of a stem from three to right inches high. The stems are produeed frecly from ereeping unclerground rootstocks and sometimes dense patehes are formed. A stretch of forest floor carpeter with these handsome leares, studeded with four-pointed stars, is a pretty sight.

The flowers fade, and are suceected by berries in the close bunches which give to the plint one of its rommon mames. In late summer, therefore, the green carpet is again hrightened, this time with coral-red fruit chusters. A little later, the leaves assume the rich erimson shates characteristic of doerwood foliage Even against this gorgeous batekglomel the berries stand out elcarly. When the sunlight flickors through the antmm wooks on this final stage in the Bunchbery development it lights up) a seche so warm and ghowing that memory recalls it with pleature in the gray ditys of Winter. 


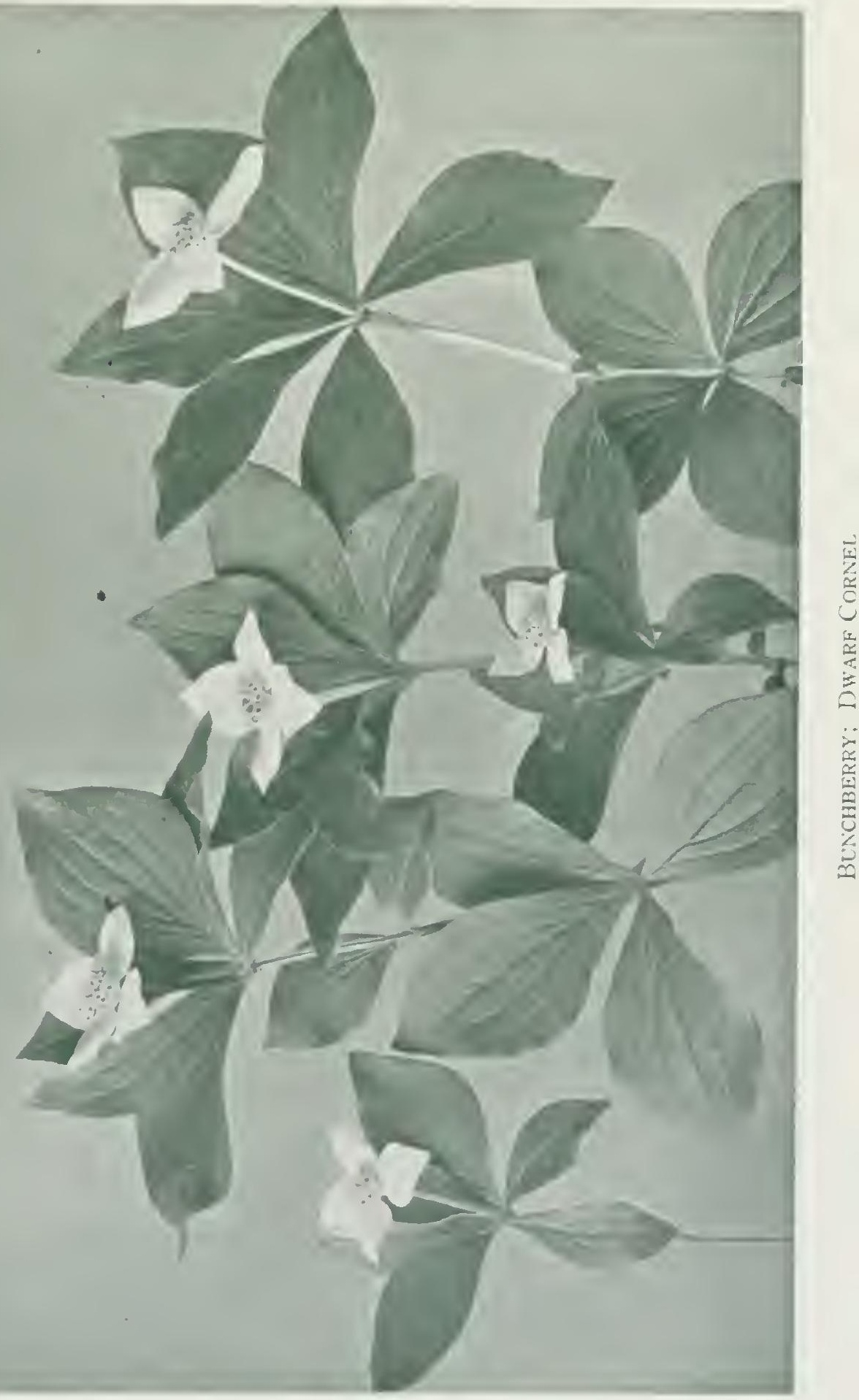




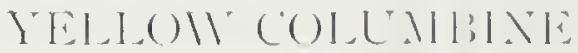

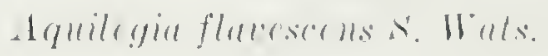

('rowroger Fing

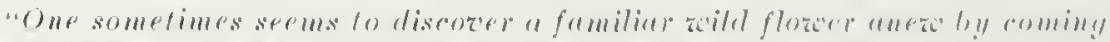

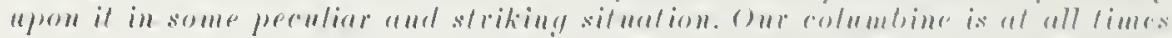

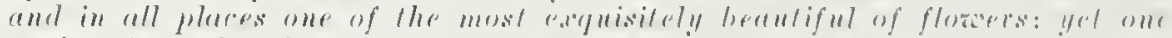

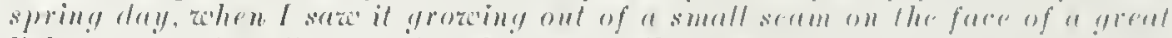

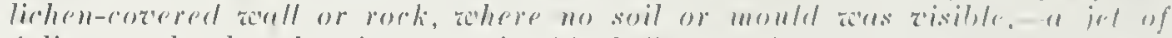

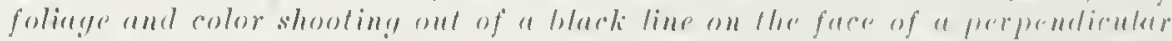

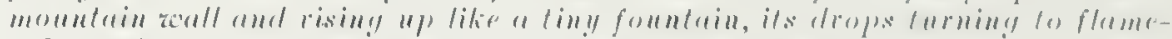

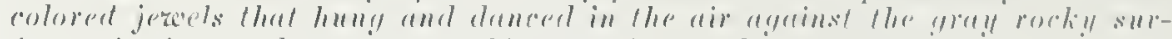

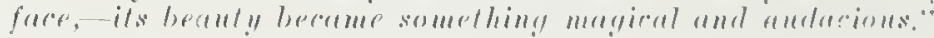

tohn Bureonghs.

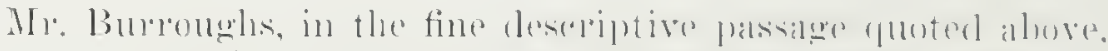

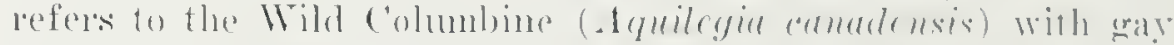

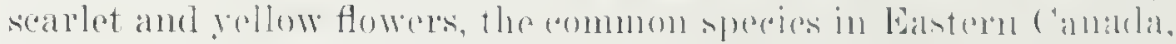

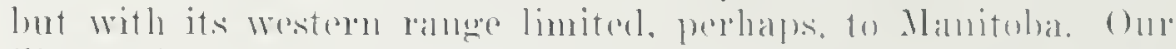
illustration is of the Yollow ('olumbine. fomel whefly in the momntains and foothills. The serpals of this moleling flowen

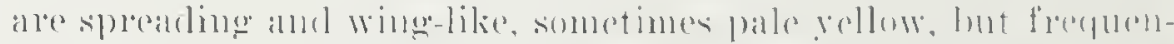

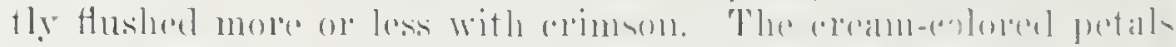

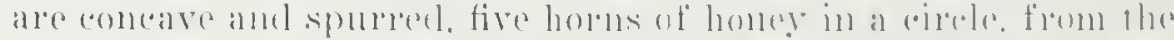

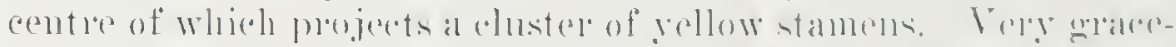

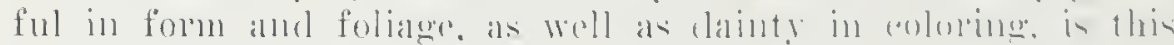
Yellow ('olumbine.

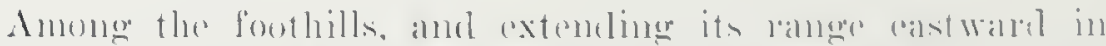

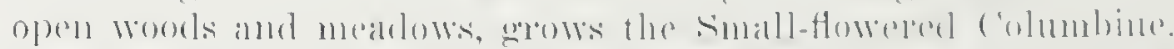

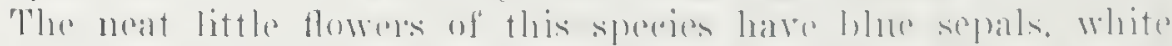

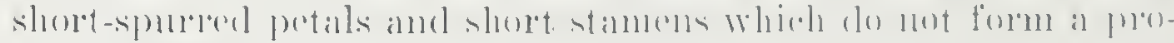

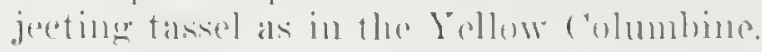

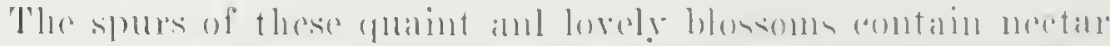

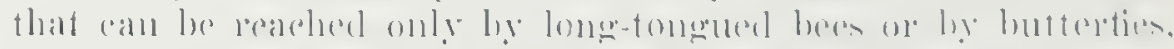

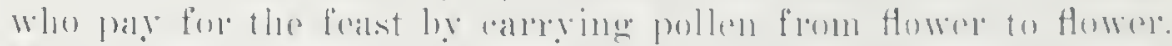

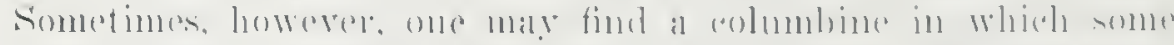

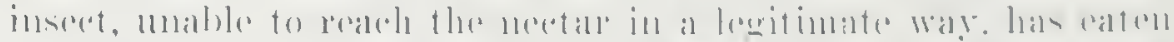

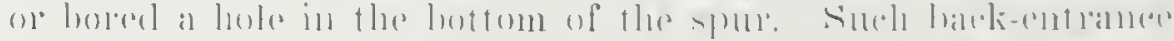

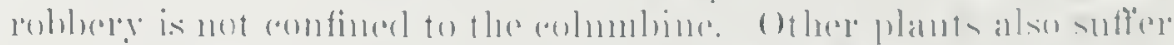

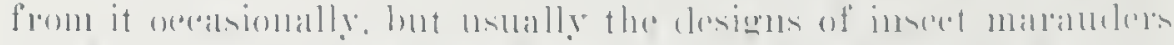

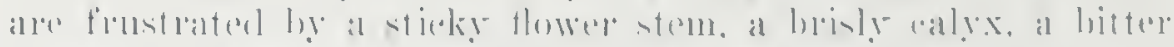

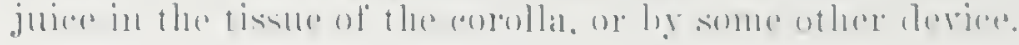




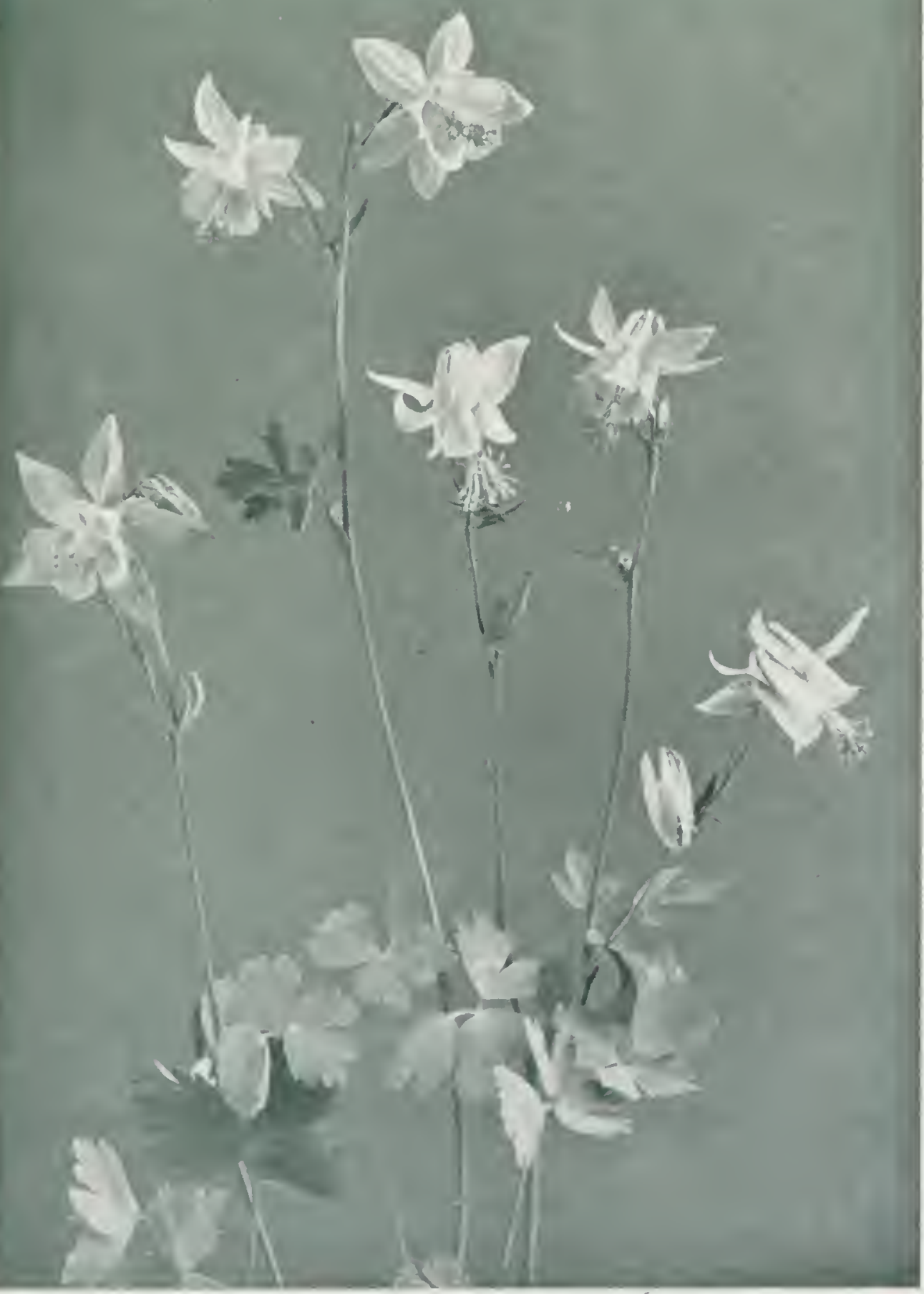

YHLLOW COLIMINE 


\section{NORTHERN BEDSTRAW}

Galium borcale $\mathrm{L}$.

Madder Family

The Northern Bedstraw is a common plant from (Queber to Alaska and southward across the international boundary. But it is most abundant and reaches its highest floral development in the northern part of its range, blooming over quite an extended period in June and July. Woods and thickets, gratrelly roadsides. railway cmbankments, and rocky hillsides are made boatiful by its light elouds of tiny four-parted blossoms, and the passing air is sweetened by its fragrant breath. Wild Bahy's Breath would seem to be a more appropriate name for this dainty flower.

In the woots the Northem Becktraw grows thirty inches high with laree, open panicles of white flowers. In the open the height is reduced to eighteen inches or less, the stems are stouter and more erect, and the flower chusters more compand. The plants pietured on the opposite page grew in elry soil in full sumshine, and were fifteen inches high. It will he noticed that the stems: are square, and the narrow leaves borne in fours. The flowers are follower by small bristly-hairy burrs.

Several other kinds of bedstratws are found in canardat. All have small, often ineonspicuons flowers, and all hatre their leaves arranged in whorts of four to right. The stems of the sweetsecnted Berlstraw a woodland species with leaves in sixes and greenish flowers in thress anre soft and weak, and when elried make a connfortahle and fragrant camp bed. O) her weak-stemmed speries are usually furnisherd with stiff, deflexerl hairs or bristles on the angles of their stems and on the edges and midreins of their leaves to colathe them to seramble oreer stronger neighthors. The burrs of many species hatre hooked hristles which ding to passing anmals or mene and in this way they berome widely distributed. 


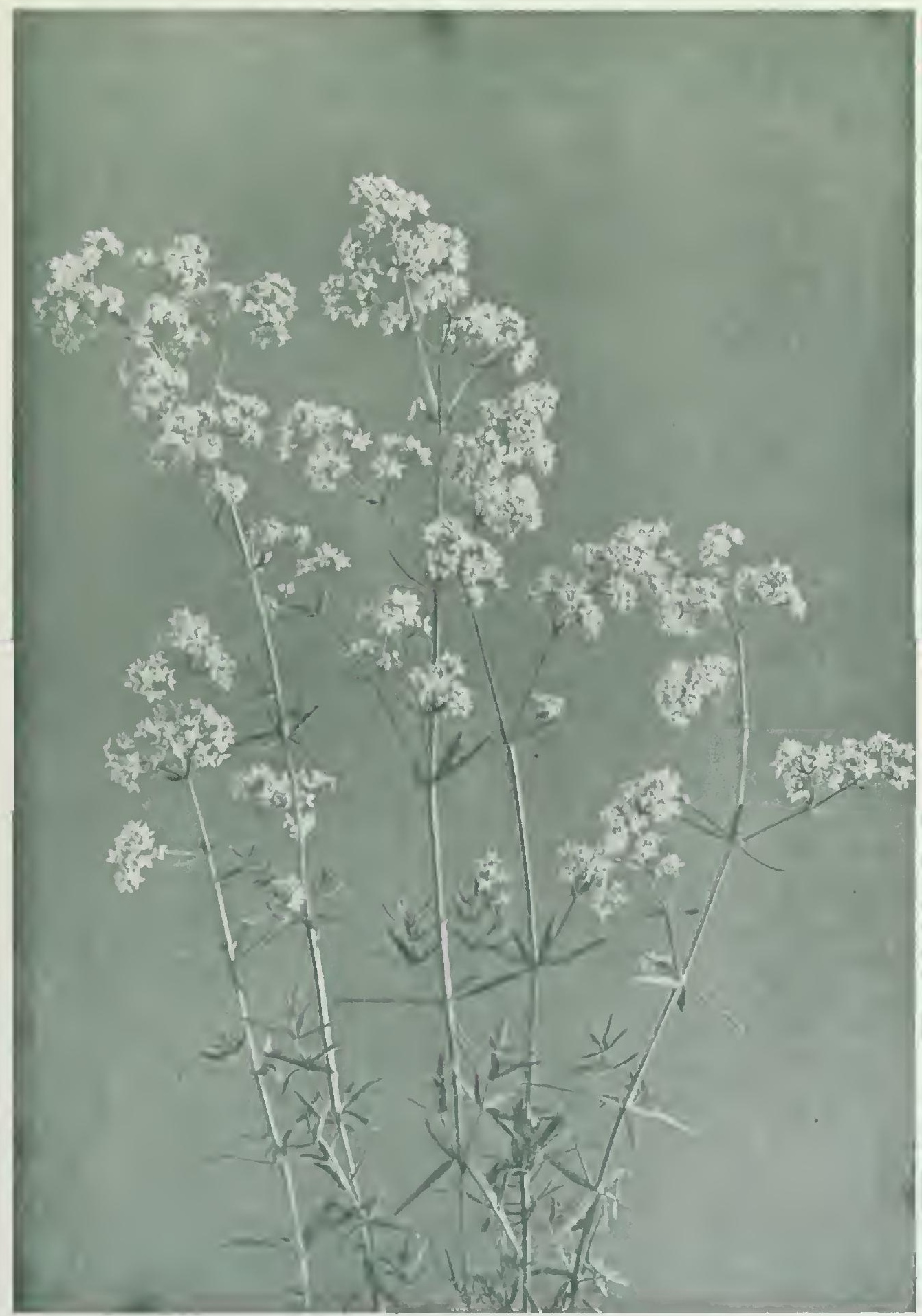

Nortifery Benstraw 


\section{SENECA SNAKEROOT}

\section{Polygala senega $L$. \\ Milkwort Familg}

The Seneca snakeroot is found in dry or rocky soil from Xew Brunswick to Alberta. It seems to be equally at home in open wooks, among thickets, or on the plans. If supplied with shade and sufficient moisture, it may reach a height of sixteen inches. On the other hand, in full sumshine and dry soil it seems also to prosper, but may be only one-quarter as tall.

The clustered stems rise from a thick, hard, and knotty rootstock. The lower part of the stem-the part hidelen in the grassis purple in color, and here the leaves are redueed to seales. The ordinary leaf is remarkibly uniform in size and shape, smooth except on the edges, and with a prominent midvein. The white flowers, borne in a terminal spike, are irregular in form. Two of the five sepals are white and petal like, and are called wings. of the three petals, the lower and larger one concave and crested -is alled the kect. The flowers never open wirlely, and most of the time are closed, giving the flower-spike the appearanee of being always in buel. The whole aspeet of this little plant is neat and attractive, and although it is not at all showy its discorery always gives pleasure.

The name Polyenala is from the (ireek meanine "munch milk." It was applied from a belief that the cat ing of it by rows incerased the secretion of the lactic fluid. Some of the other species may he partaken of hy atatle, but this one does not seeme to be eaten. The roots, howerer, althomgh no longer comsidered to be a remerly for smakelite, have some medicinal ralure, and there is a linited commercial demand for them. 


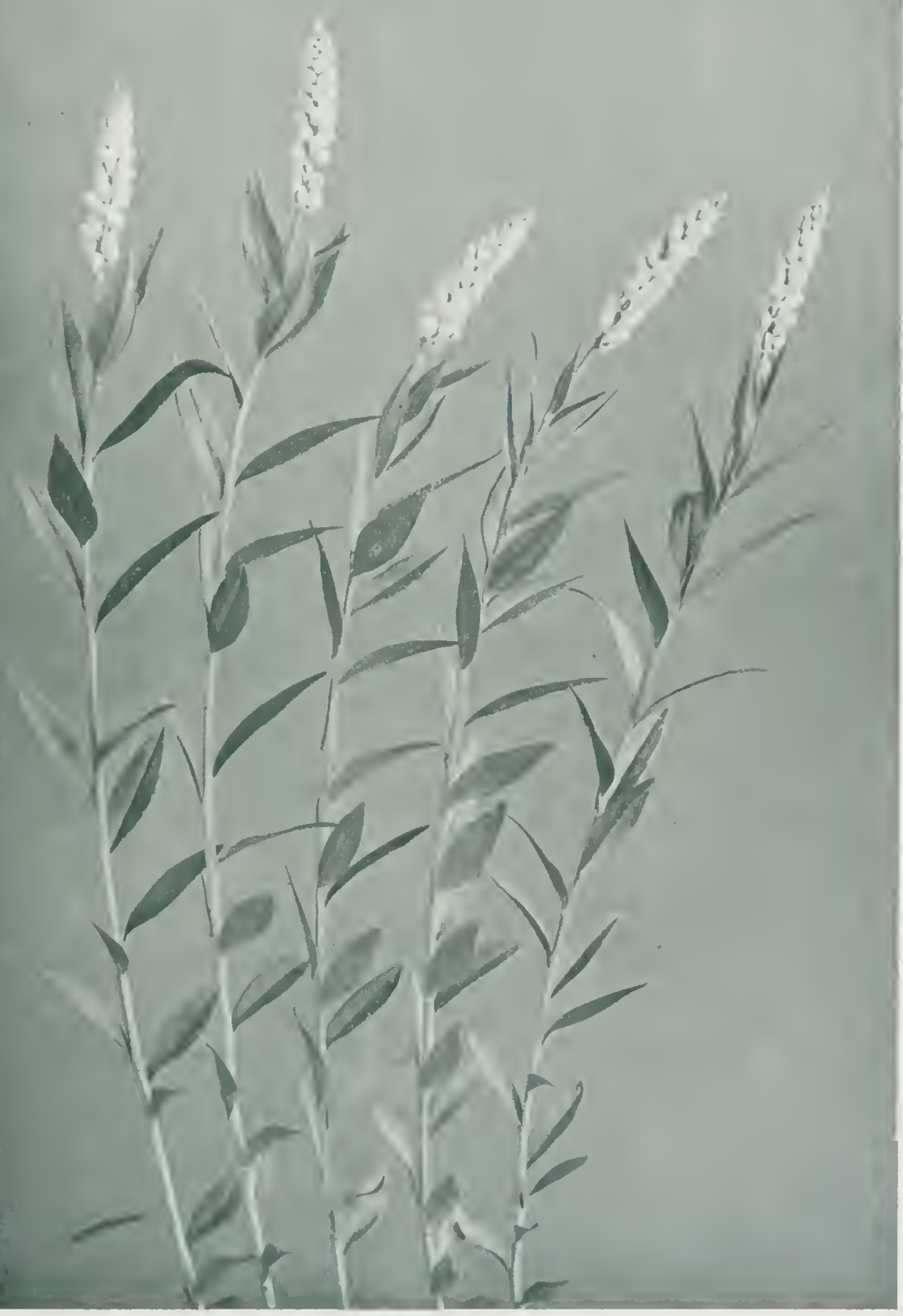

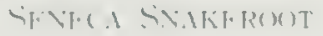

.). 


\section{RED LILY; WOOD LILY}

Lilium montanum A. Tels.

\section{LILY FAMILY}

The Red Lily, in slightly different forms, is common in many" districts from Ontario to Alberta. It grows in open woods, anong bushes, and along roadsides in rather dry soil. Csually each leafy stem is crowned by a single red, or orange-red flower, although vigorous plants may produce two, three, or even five in a cluster.

Admired for its beauty, and easily foumd hecause of its large size and vivid color, the Red Lily is eagerly gathered. In rumal homes and sehools it may be seen in great bunches packed into vases, cans, or pails. Town and city dweblers returning from an evening's rum into the country or from a First of July cxemrsion have their arms, one might almost say their cars, filled with the bright blossoms. The comme for miles around is stripped. Those who gaily pieked them had probably a hazy idea that wild flowers just happen, and in sone way will always happen. But into the flower the plant puts its supreme effort, an effort that leaves the roots lax and depleted. Their enerey can be restored only by the work of the leaves durine the summer. 'These Lilies and many other flowers are pulled up or broken off with all their leaves attached, henee the roots in their weakened condition either die or at best require several years to regain strenght enough to prochere more flowers.

The beantiful wild flowers are the culmintution of Natures: efforts applied to plant life through millions of years. 'Plueg should be the heritage of mankind for all tinne, hut the chosecst are in (langer of clisappearing in a single generation. We have learmed to hunt song-birels with ficlel-glass amd comera instral of a gum. lat us learn to enjoy wild flowers where they grow. Earle lats a life story well wortle realinge, legible to the pationt and sympatlentir observer. 


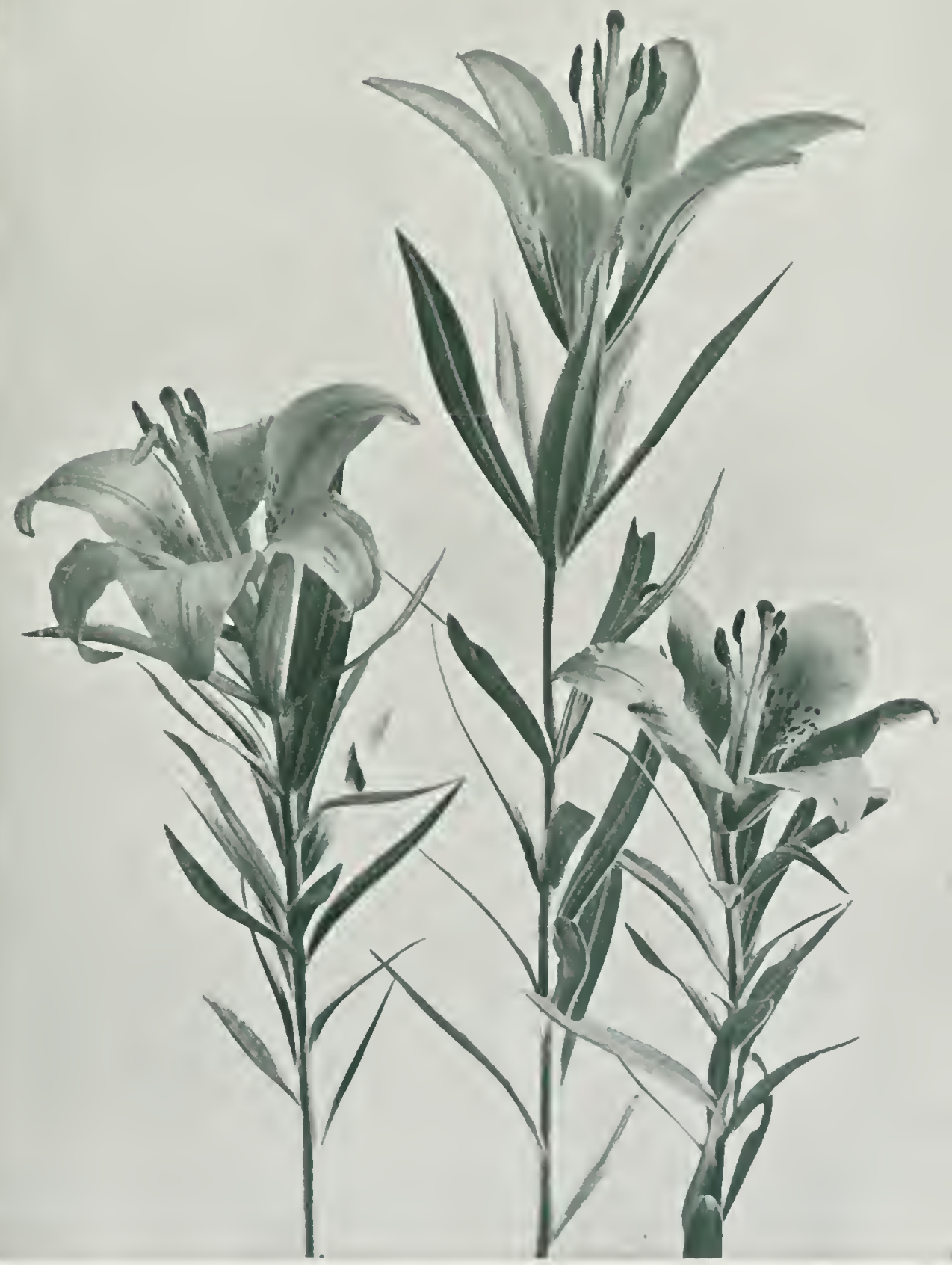

REI) L.11.\%; II (YOI) I.II.Y 


\section{IN A WESTERN WOODLAND}

\section{.. . . . . . Nestled at his ront Is beauly such as blooms not in the glare of the broad sun. That delicate forest flomer II ith secuted breath, and look so litie a smile. serems as il issues from the shapoless mould, An emanation of the imbelling Life."}

1 Forest 11 ymm- biymul.

Something there is in the perspective of a woolland glade that has a tranquitizing and restorative effect mpon the mind. Mnalysis would but destroy the charm. And yet, just as one is hore aware of a different mental attituche when "far' from the mackling crowd's ignoble strife," so one must notice the special appual made by woodland flowers. Usually they are smoother and broader of leaf, more delieately colored, and generally more gracerful than their kinsmen of the plains. Nor is variety of plant

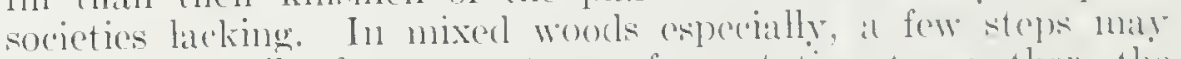
take one readily from one trpe of regetation to anothere, the determining fartors of the change, of course, heing the amomut of sunshine fincling its way through the foliage and the amomnt of moisture in the soil.

In the picture opposite, showing the sloping bank of a woorlent ravine, we have in the foregromel a rather companet gromp of spruce trees, and beyond the sumlit aspen forest. In the denser coniferous shate grow mosies and lichens in abundance lout flowering plants are fow. We naty find, howerer, an oflel specinen

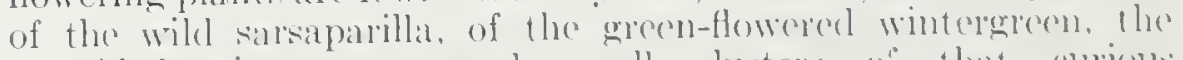
one-sided wintergeren, and small shoteps of that cmions:

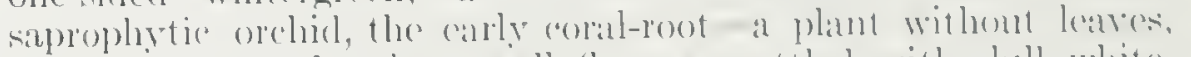
just pale stems bearing small flowers motterl with dull white, rellow, and purple. Mloving ont into the lighter shate on the

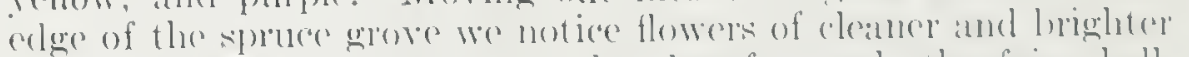

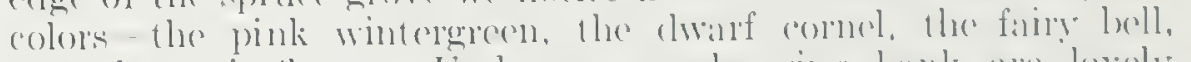
and the twin-flower. Conter an overhamging hank are loxply

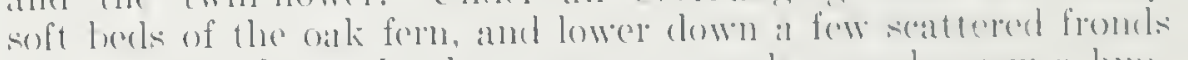

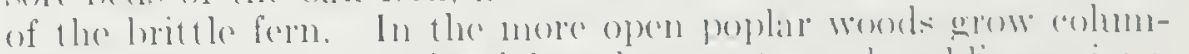

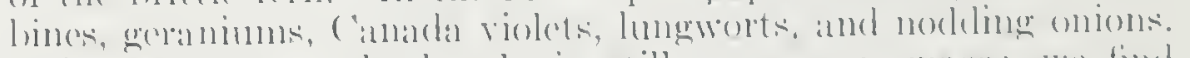

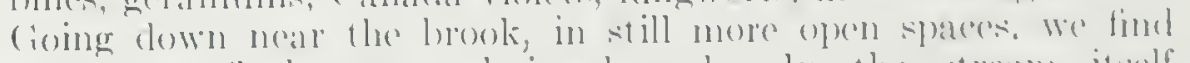

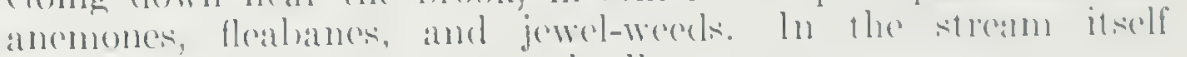
are berse of tar damty blue speredwoll.

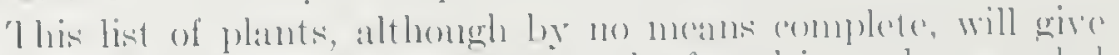

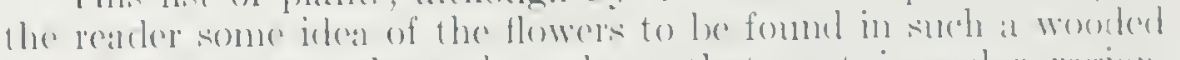

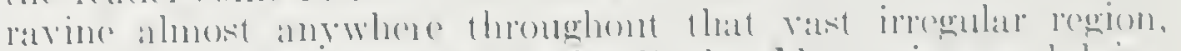

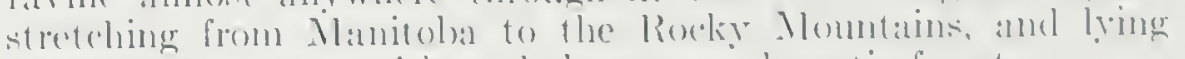

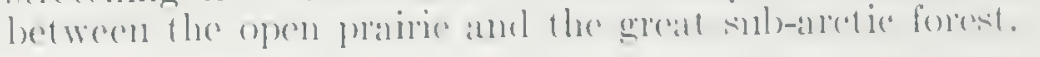




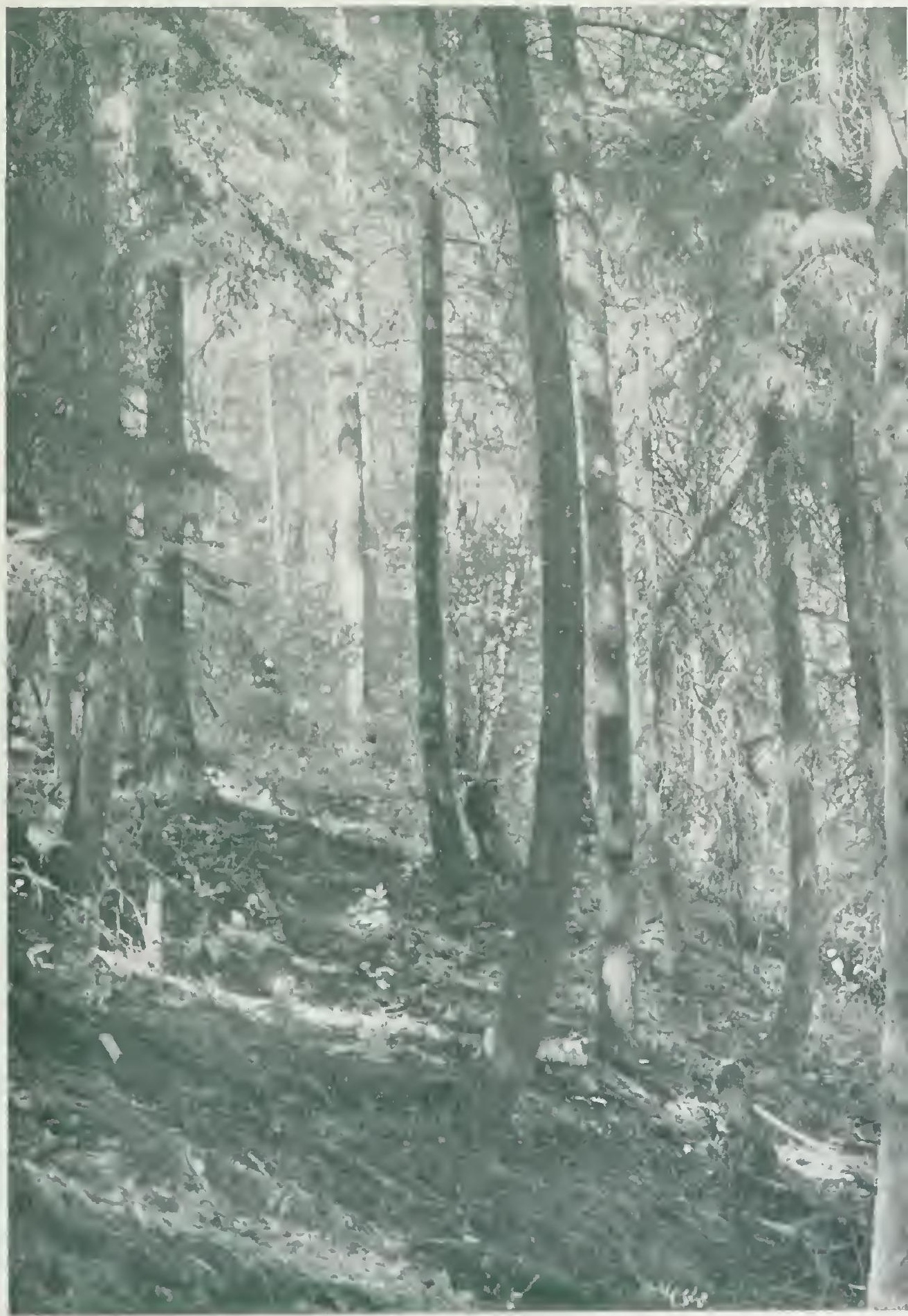

IVA MI:TER:X Haxm INI) 


\section{PINK WINTERGREEN}

Pyrola asarifolia Michx.

HeATH FAMILY

( Jur woods in carly spring lack many a delieate forest flower that some of us knew and lored in the East. We do not have the frequent April showers that bring forth May flowers. After the first flush, heralding its advance, the floral pagrant seens sonctines to lablt and mark time, waiting for the summer lains. Meanwhile, the days lengthen, until only a fow hours of darknese remain. Then comes the rain with its almost numarulons quickening of regetable life. Ferdure flows over the praties, up the hills, and into the woods, quickly followed by sucersive watres of gaty color. In the lighter aspen shade there are nore flowers than beneath the heavier foliage of the hardwood forest, and our midsummer woods are adorned with many bright blossons. None is more ornanental than the Pink Winterereen which grows in great profusion in rich, damp woodlands and thickets thoughont our territory.

In late June or early July, from the cirele of thick, shining, evergreen leaves, rises a slencler stent, five to twelve inches high. bearing numerous nodding flowers, atch with a curved and protruding style. The petals are softly shated from pare pink in the centre to deep rose on the elges. When a fragrance like that of the eultivated lily-of-the-ralley is combined with sulch beanty of form and color it perfects a plant of ran ro loveliness.

The large buds, from which the flower-stalks spunge. Were fully fomed duming the previous summer. All parts were there _. stom, calyx, corollat, stamens, pistil beatutifully formed in miniature, each separate flower-bud packed away beneath its own scale, and the whole conclosed hy a fow largerered scalles. In this eondition, with perhaps a light hlanket of laukes, they were exposed to zoro weather hefore the snow cante as additional protection.

This canceful preparation of palts in minature, so beatutifully" exhibited by the Pink Wintergeen, am be traced, in ranging degrees, in ofluer plants, and, gromerally speaking, alcounts for the rapid development of vegetation when the quickenting breath

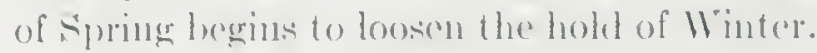




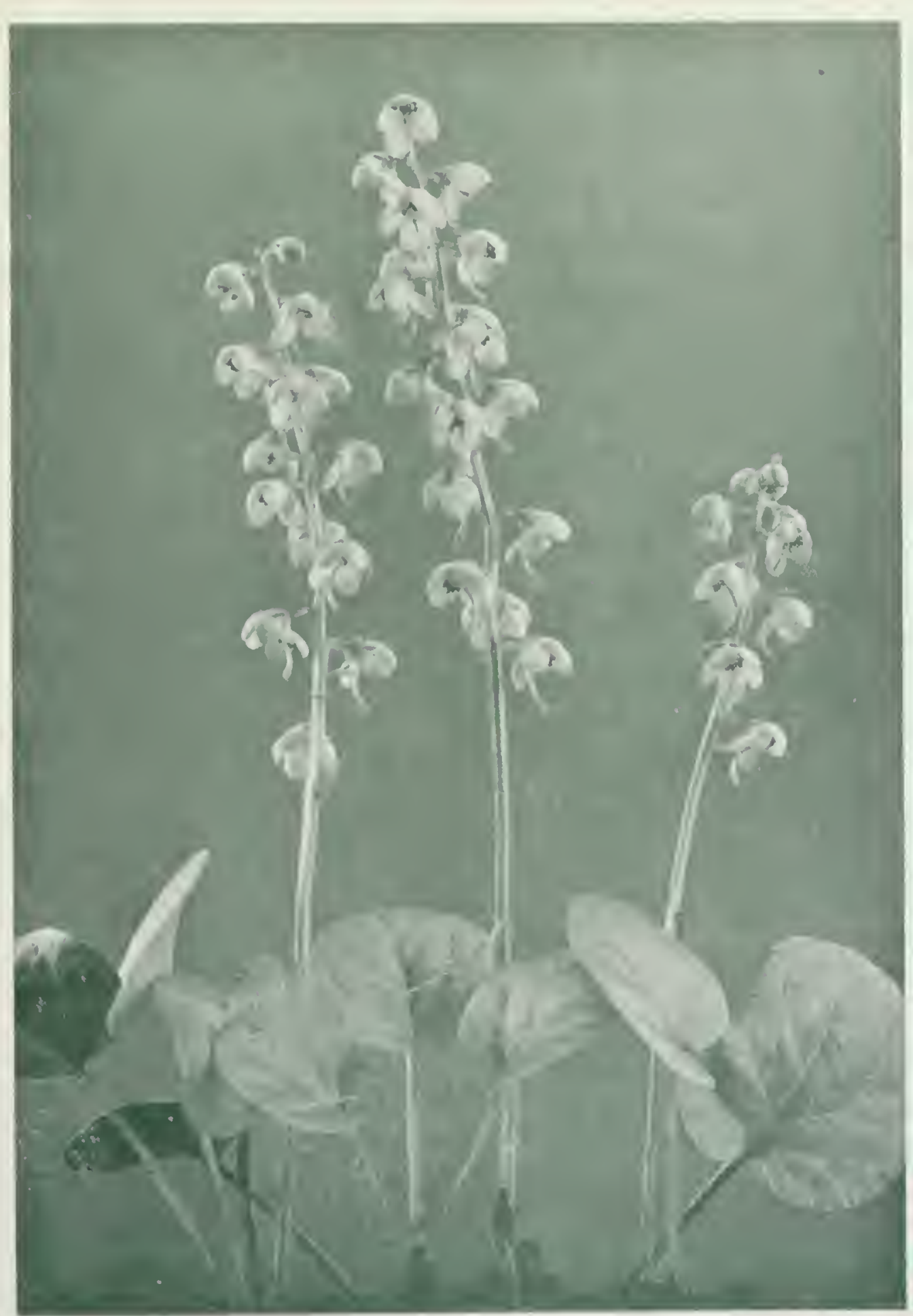

I'INT UINTERR,RET 


\section{ONE-FLOUEREA WINTERGREEN； SINGLE BE.\UTY \\ Moneses aniflora (L.) (i)}

\section{Eat LI LAMHYY}

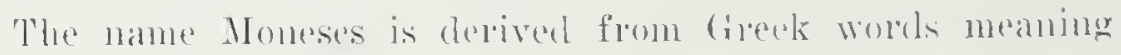

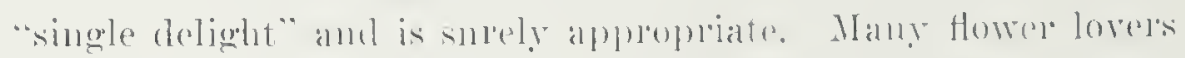
consider this ome most beantiful wile flower. and the finding of

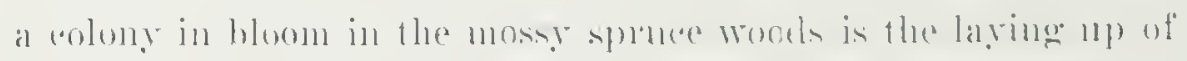

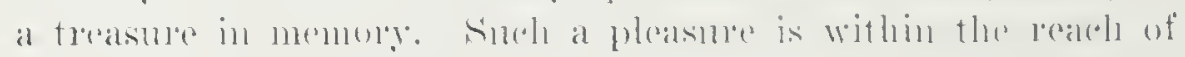
many, for the plant in widely distributed. although not as lonmonon

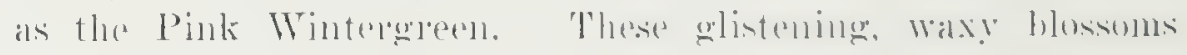

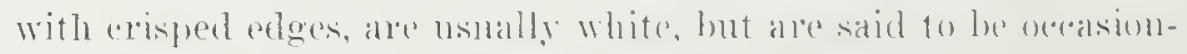

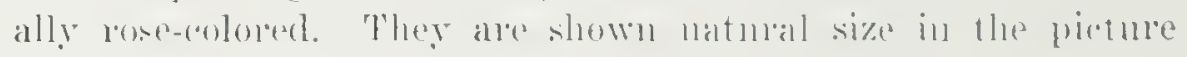
opposite.

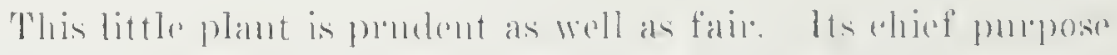

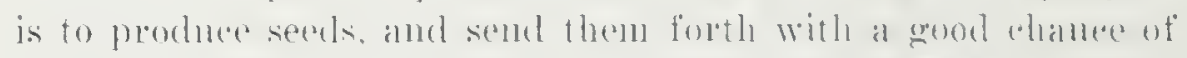
smoress in life. The vitatity that eomes foum coss-feltilization

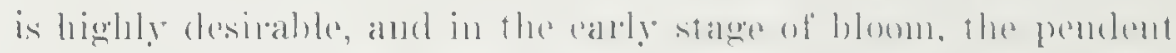

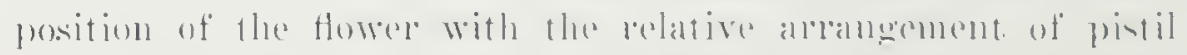

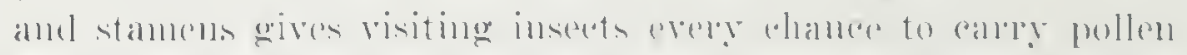

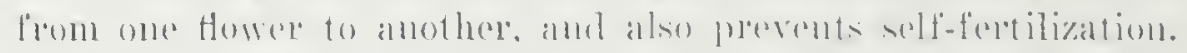

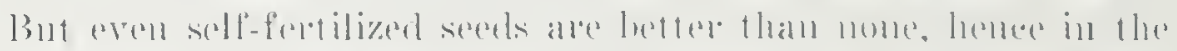

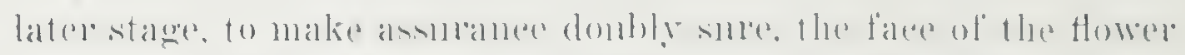

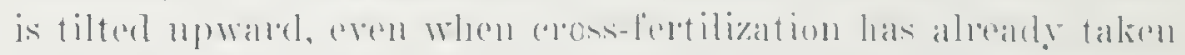
plater, giving the stole an oblingue postion and bringing some

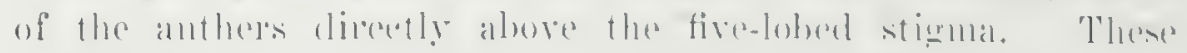

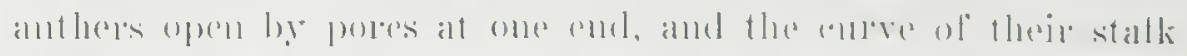

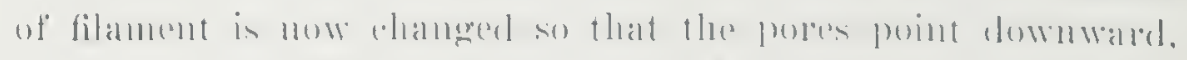

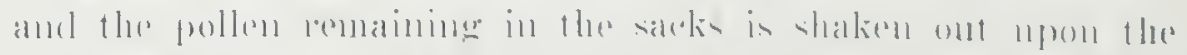

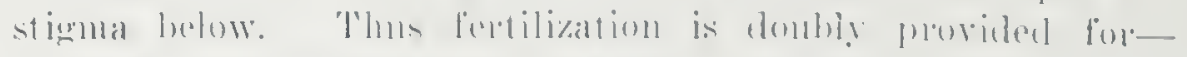

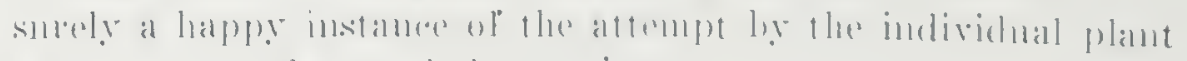

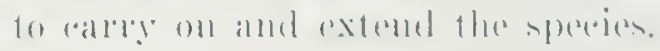




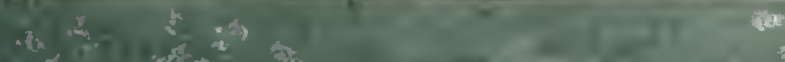

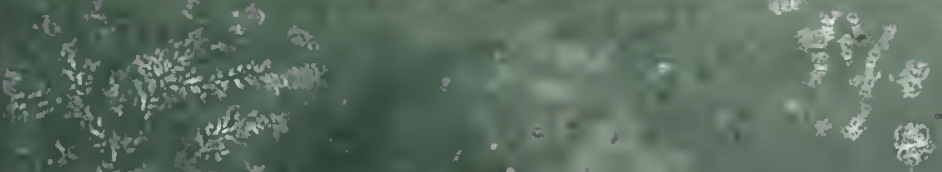

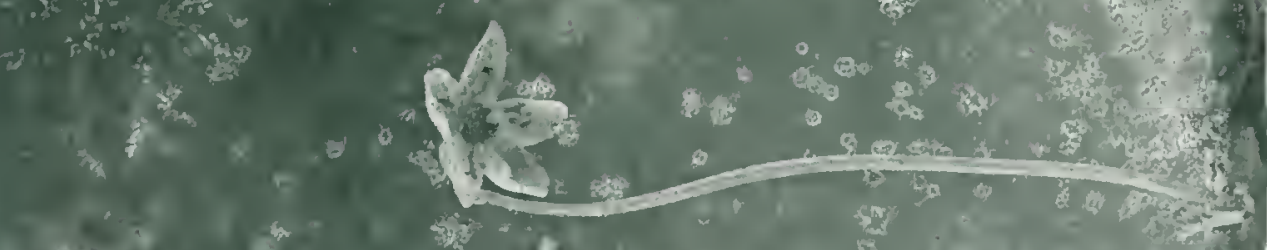

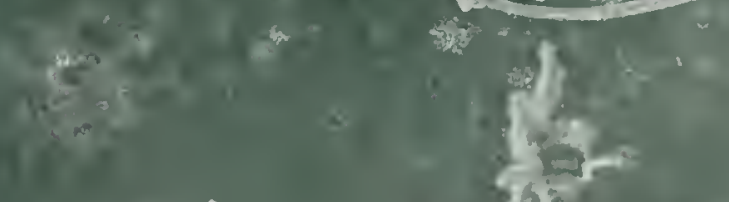

3.

(6) 19

\section{$\bullet$}

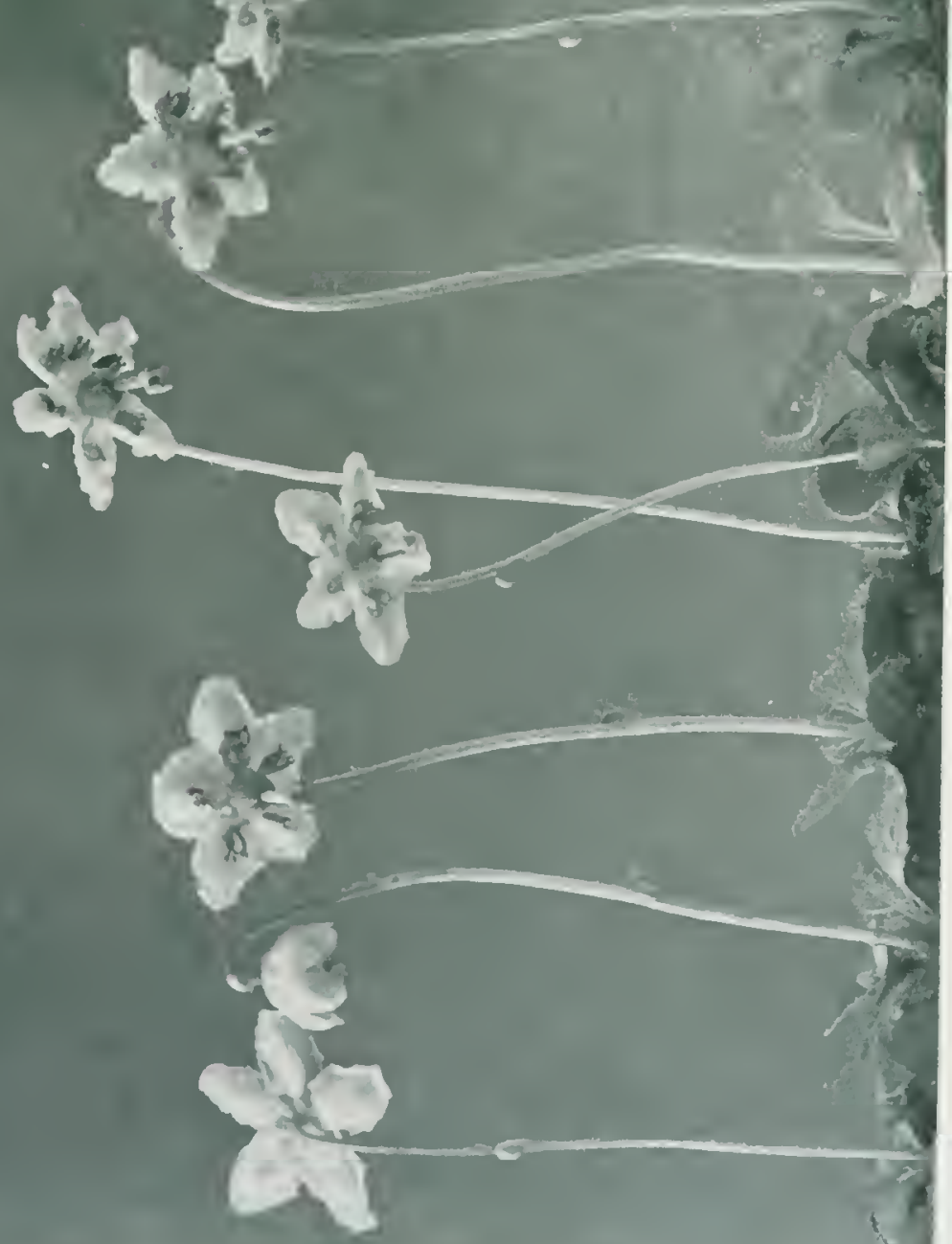




\section{PURPLE GERANIUM OR CRANE'S-BILL}

\section{Geranium incisum $\mathbf{N}$ ull.}

\section{Geranium Famir}

Several Geraniums with comparatively large flowers-threequarters of an inch or so in diameter-oceur in Western Cinacla. The Spotted Geranium, the common form in Eastern Canada has apparently not found its way westwarl beyond Manitoba. However, it is replaced by at least two handsome speciesRichardson's Geranim, with its thin leaves and delicate white flowers, found chiefly in woods and thickets; and this Purple Geranium, a more hairy and rugged plant, with bright purple flowers, found in open meadows as well as in shaded places. Both grow to a height of two feet or more, and bloom from late June until August. In both, the leaves contribute not a little to the attractiveness of the plant.

After the petals have fallen, the seed ressels develop in such a way as to give these plants the name of Crane's-bill. "The five carpels or seed-pods, growing in a ring, suggest, remotely, the head of a bird, ancl the stout column, which rises from their centre, suggests the beak of a crane. 'This column consists of a central five-angled axis with which are combined five stout bristles, each one of which is produced up from, and forms a part of, one of the five seed-pods. As the seeds ripen, the column dries unevenly and in such a way that there is a grat tension in each bristle. This tension is crer increasing until the seedpod suddenly breaks away at its base. The bristle, coiling upward with great force, acts as a spring to fling the seed a considerable distance from the parent plant. After the explosion the enpty (ases liang from the top of the eolumn's axis in a pretty chandelierlike group).

On a dry, warm day it is interesting to watch the operation of this novel process of seed distribution. If the observer be presserl for time or lacking in patience lre may hasten its action, for a touch will often spring the mechanism of this vegretable catapult 

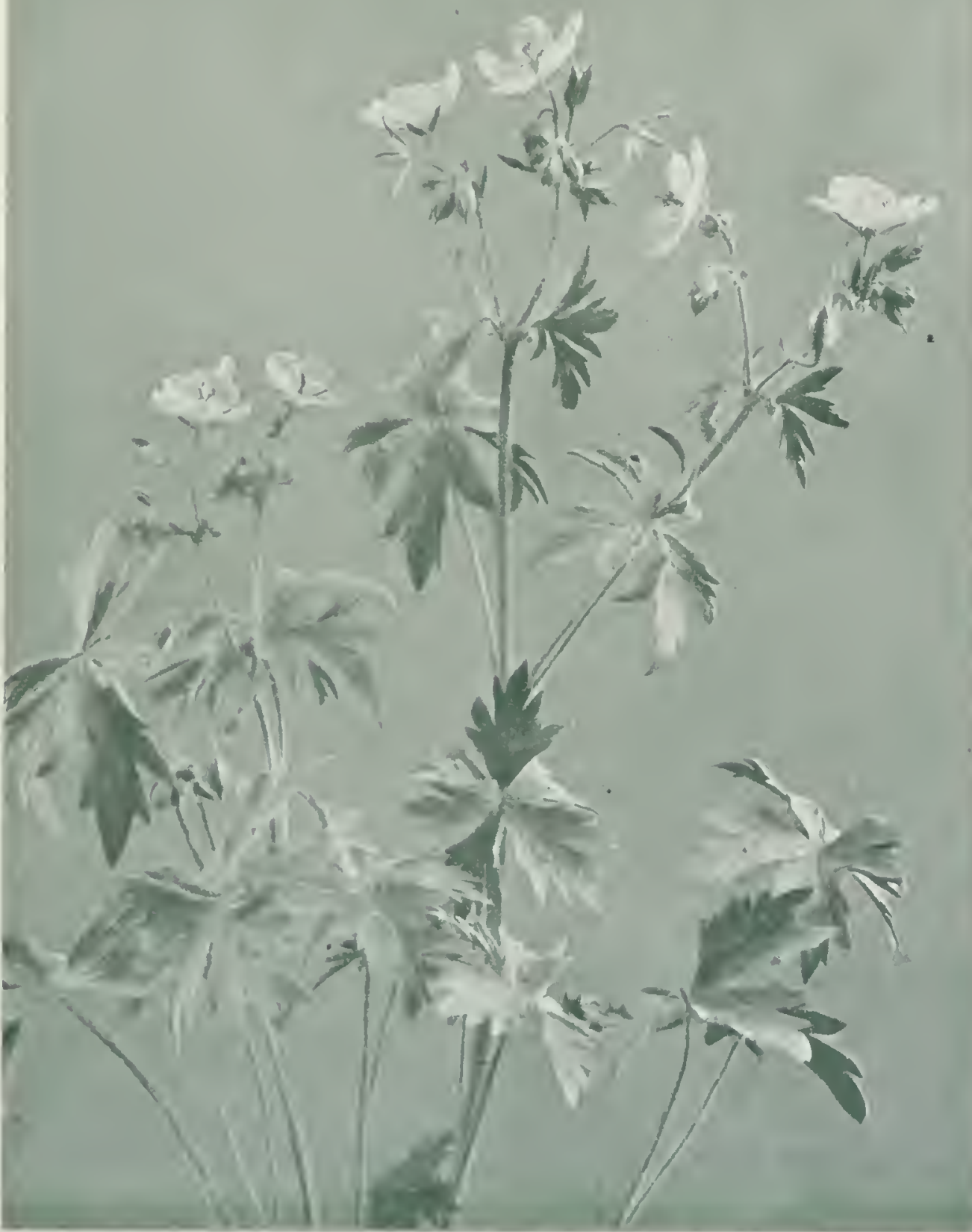

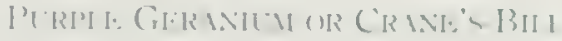




\section{TALL MHITE CINQUEAOIL \\ Potentilla arguta Pursh \\ ROSE FAMIIY}

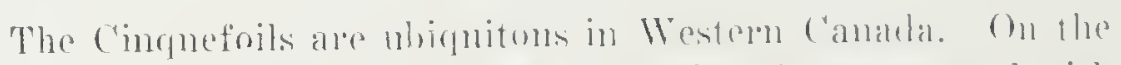

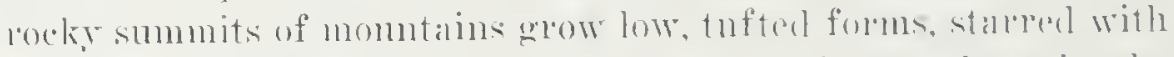
short-stemmed blessoms. In moist and fertile mealows in the

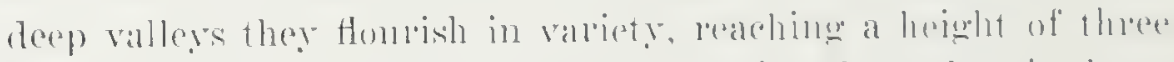

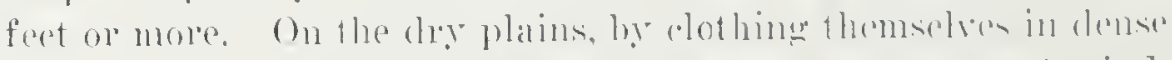

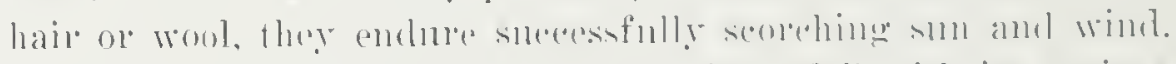

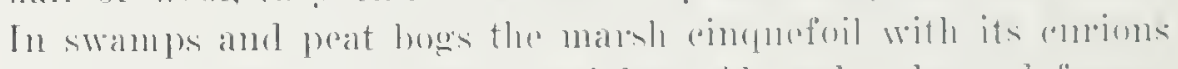

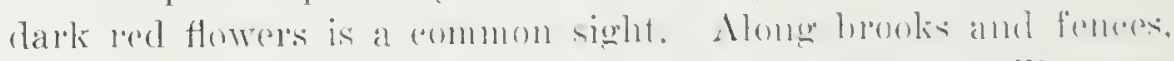
among piles of rubbish, and in enttivated gromul ome will arery-

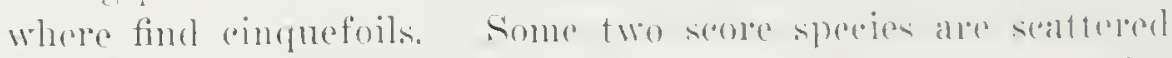

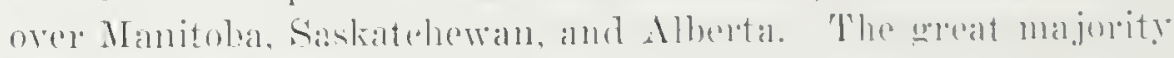

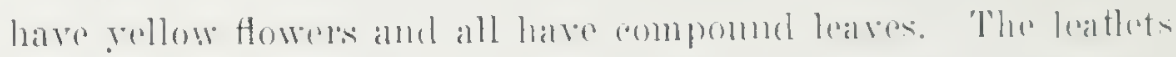

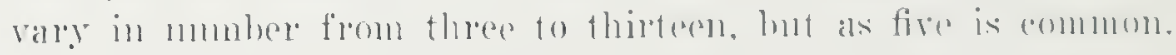
the name, eincunefoil, has been applierl to all.

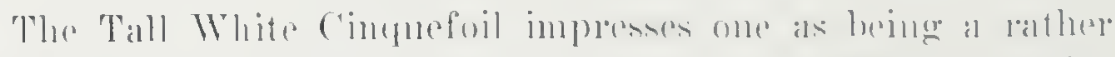

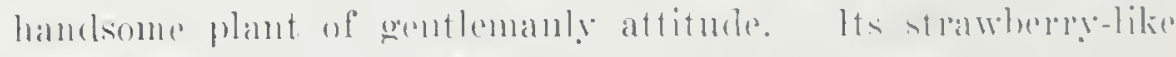

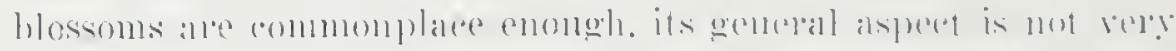
different from some of its werely linsfolk, get it lats an alle of

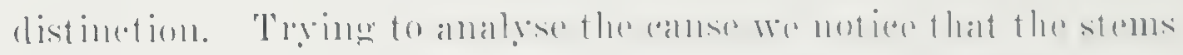

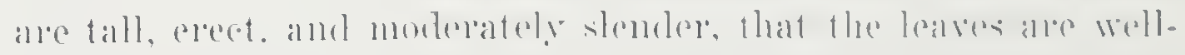

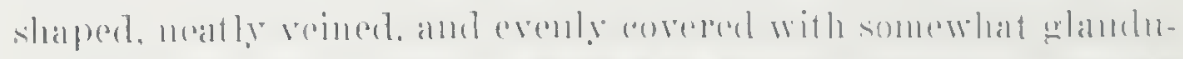

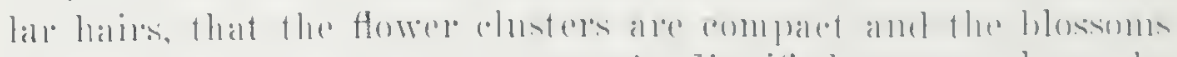

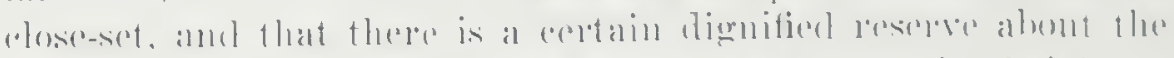

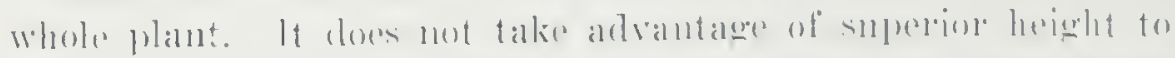

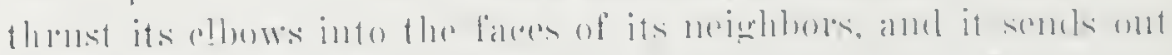

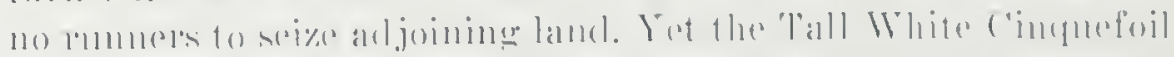

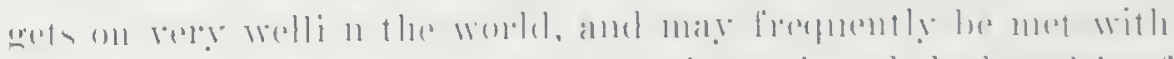

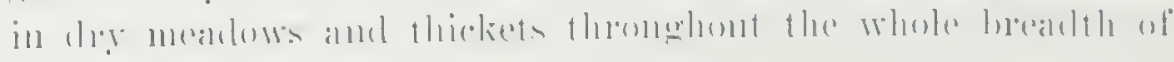

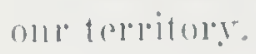




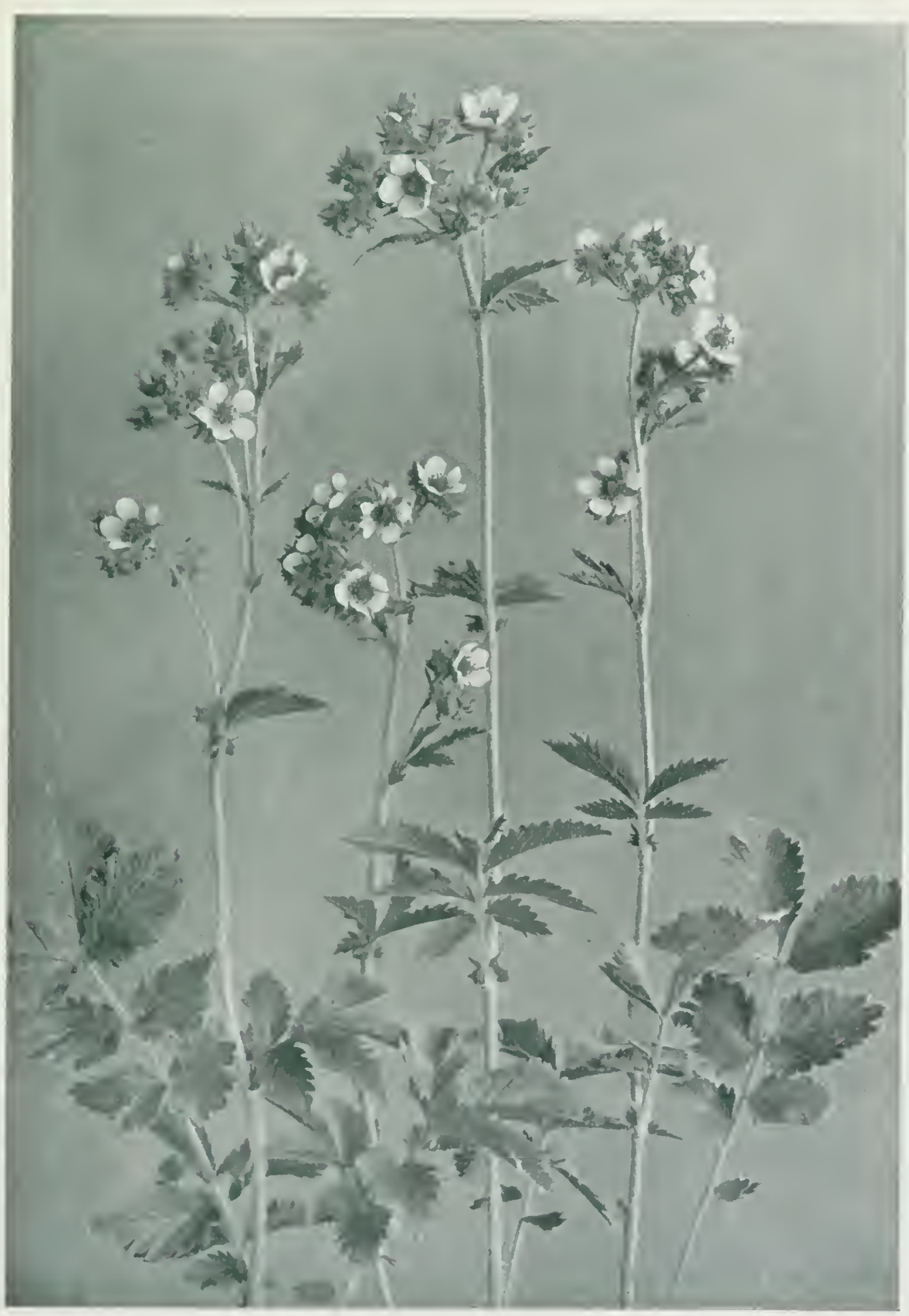

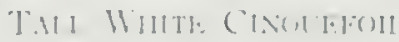




\section{COW PARSNIP}

\section{Heracleum lanatum Michx.}

\section{Carrot Famil}

This lusty perennial of decorative character is widely distributed, from Newfoundland to Alaska, and south fiom North Carolina to California, but reaching its greatest profusion in the North where one of the rivers is named "The Parsnip" because of the abundance of the growth of this plant on its banks. In the open it grows three or four feet high, and ahnost as many wide, while in moist, sharled places it stretehes up eight foet. It prefers damp soil, as its broad leaf-surfaces inclicate. The hollows in these, caused by the wavel and ented erges, the shallow chamels on the stakks of the lower leaves, and the inflated sheaths on the upper ones, aid in catching rain and conveying it down the stem to the cluster of fleshy roots.

The white flowers, opening in Junc and July, are horne in great umbels sonetimes a foot across. The onter petals of the ontside flowers are enlarged, spreading out where they find room, so making the whole head more conspicuous. Such massing of many minute flowers, in various forms, is common among plants and adkls to their beauty and efficiency. In the one moler. consideration, the large, honey-laden expanse of white attracts many inserets, anct the flat chusters afford a firm and ample feerling platform for these guests. In leturn they carry the pollen from onc flower to another, and from plant to plant, so loringing about the cross-fortilization neressang to maintain the vigor of successive generations. 


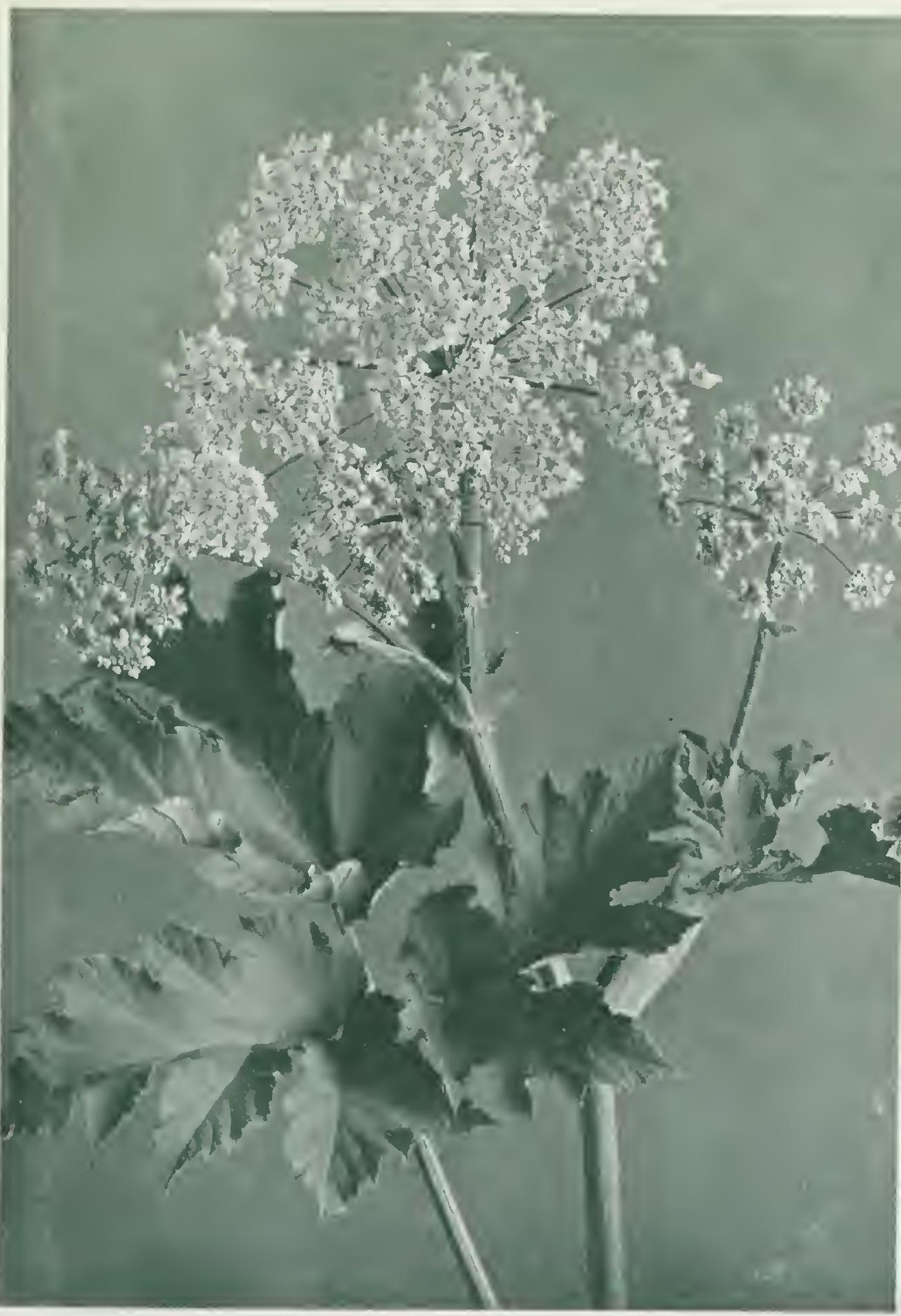

COW PARSNIP 


\title{
PRAIRIE PINK; SKELETON IVEED
}

\author{
Lygodesmia juncea (Pursh) D. Don \\ Chacory Family
}

This meagre plant is in striking contrast to the mulprageous Cow Parsnip which we have just been considering. The one suggests the dry plains of the South, the other, the mnist ralley's of the North; the one suggests stern struggle against conclitions acherse to life, the other, easy enjoyment of all the good things in the plant workl. Yot I have secn them growing within a few hundred yards of each other, one on a grarelly, sunny slope, the other in the springy soil at the bottom. Each is a sucerssul and (if we share Wordsworth's faith "that "rery flower enjoys the air it breathes") a haply plant.

The Prairie P'ink is suceossful because it has adapted itsolf to hart conditions and ordered its lifo with frugality in all things. The roots are thick, woody, and decp in the soil, hence are not shrivelled up by drought. The hares are redued to narrow, pointed bracts in oreler that the seanty supply of moisture may not he lost by rapid transpiration. Fren the flower-heacls have only fire florets insteat of the one humberl or mone foumd in many other nembers of the family-the dandelion for instance. the flowers, which open in hright weather and remain open but a short time, are a protly shate of pink. 


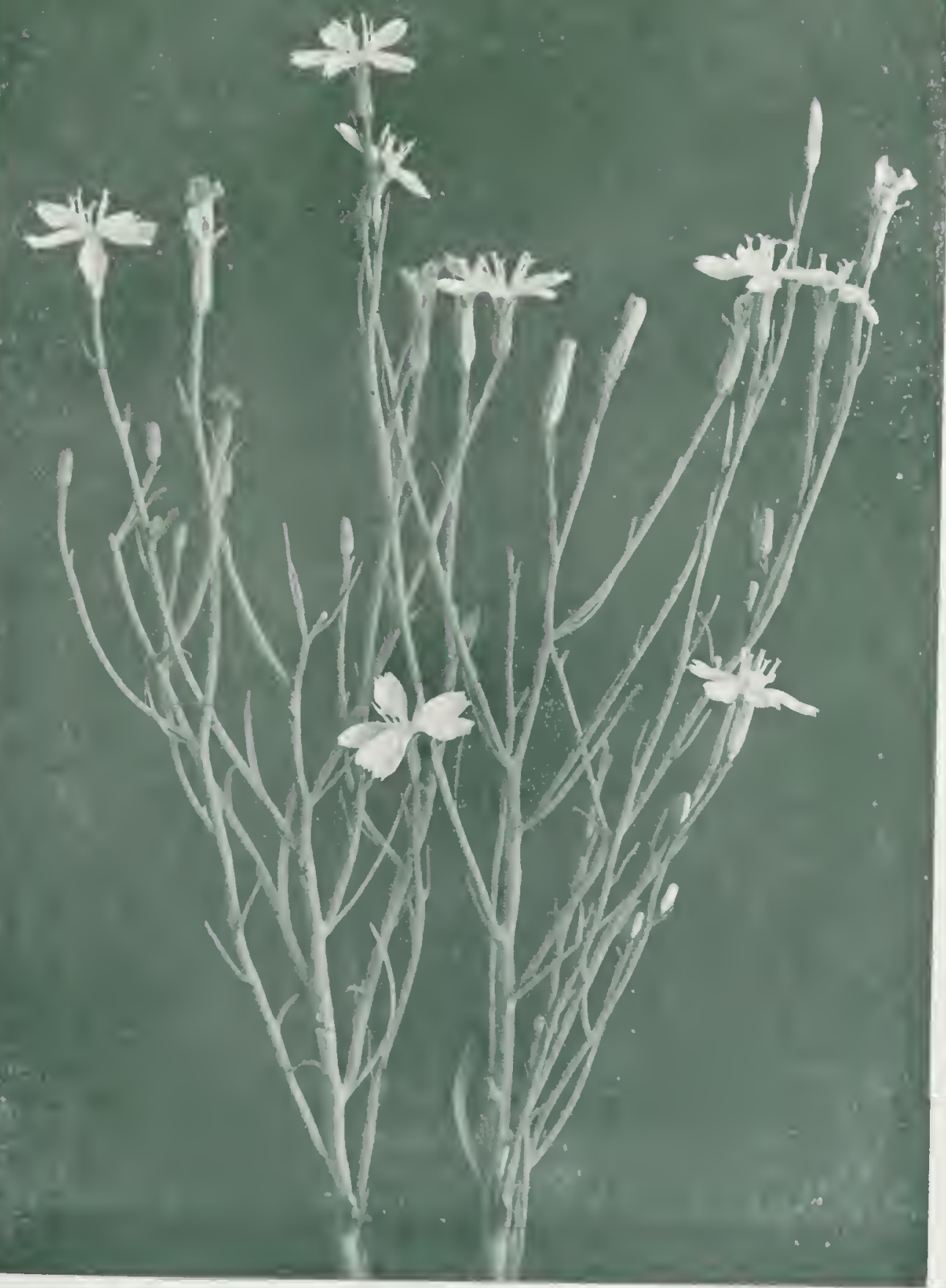

P'RAIRIE P'INK; SKHETON WEED 


\section{SCARLET GAURA; BUTTERFLY WEED}

\section{Gaura coccinca Nutt. \\ liventag-Pramose famey}

The scartet (ianral an interesting plant of the open pratrice, may often be found erowing in gravelly soil from Mandobat to the Foothills of the Rocky Momntains.

The much-linnched stems are usually decumbent (that is, reclining at the base with their tips ascondinge and vatry in height from four inches fo a foot or mole. 'Phe smath and mumer'-

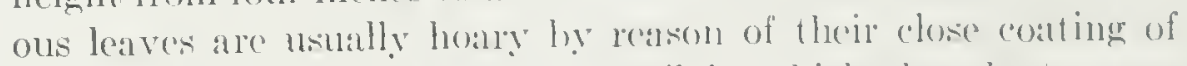
short, gray hate. The drier the soil in which the platet grow: the heavier is this protective coveringe.

But on the flowers one chice interest centres, for they have the curious habit of expmeling four pure white potals and shortly

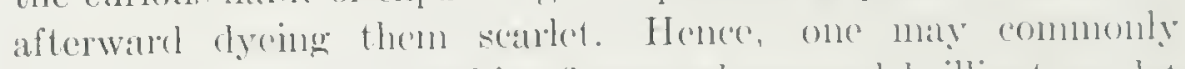
fincl flowel-spikes with white flower's alwore and brillinnt scarlet ones bencath. This stanling color selheme is renclered more striking by reason of the fare that the eight prominent stamens have white filaments and lange brick-bed anthers. Simetimes, howerer, the petals rematin white during the whole of a wallm sunshing day. This was the ease with the plants whose photograph, reproduecel on the opposite patace, was taken by the madsiche at four o'elock of a day in early July. It will be noticed that the petak are drocplong somewhat from the arelent heat, yet no blush of red liats yet appoared. Some of these plants were tation home and placed in at crob collar overnight. Next moming the floweres of the previons day wore mostly withered, hat five or six fresh,

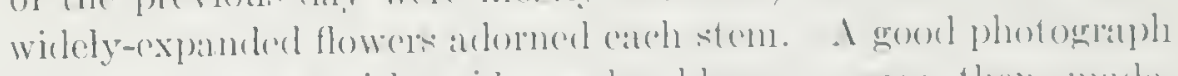

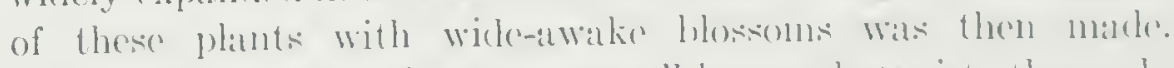
subseperenty, when shown to a wedl-known botanist, the carly morning photograph quite purzhel him, white the one taken in

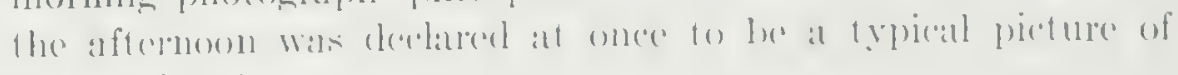

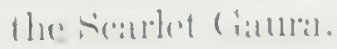

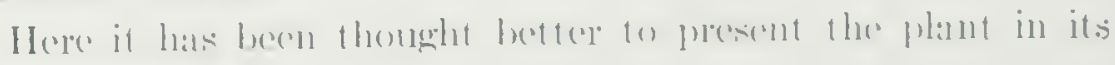
drowsy atsper. 


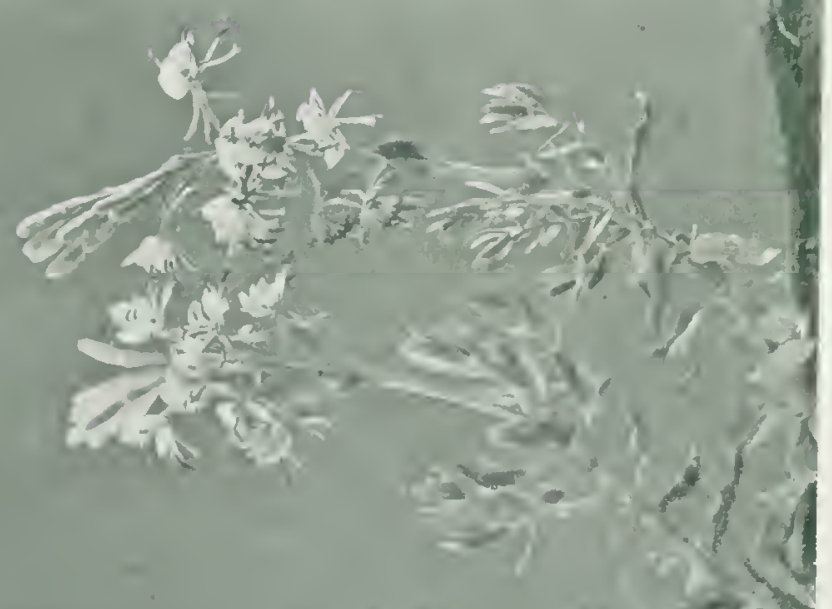

S.

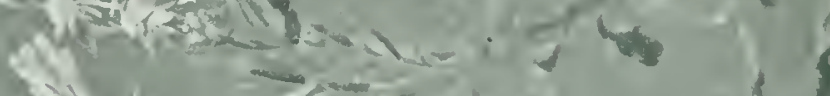

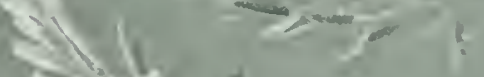

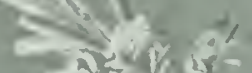

के

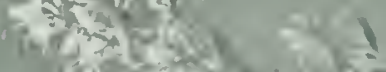

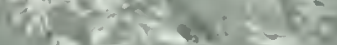

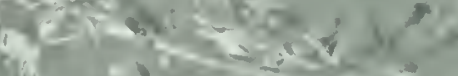

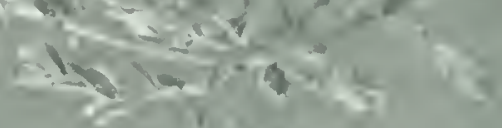

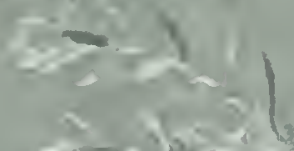

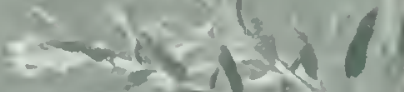
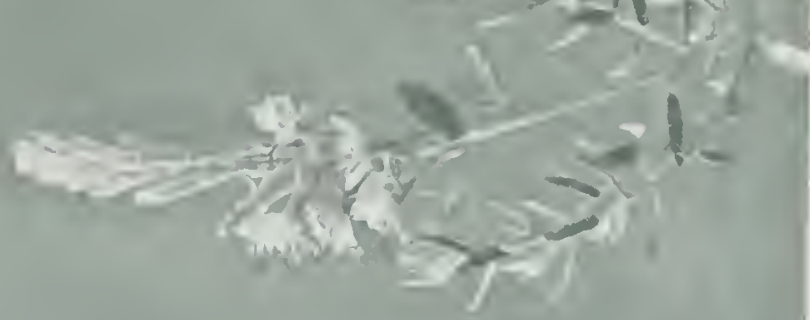


\section{PURPLE PRAIRIE CLOVER}

\section{Petalostemon purpureus (Tent.) Ridb.}

P'EA FAMILY

The Purple Pranie Clover is a pereminal with a deep, tough, woody root from which grow clustered stems in height from one to three feet. 'The smaller stems are simple, the larerer branched, and each stem or branch is terminated by a short, dense flowerspike. Before the flowers open, earty in July, the spike is a soft, pretty shade of gray, with spiral rows of closcly packed bucls. The lower buds open first, and the circle of hright purple corollas travels upward. The color seheme of the flower is rendered more striking ly reason of the leep orange anthers that project beyond the corolla.

The strueture of the flower is so different from the ustual pea blossom that young botanists often have difficulty in identifỵing it. In the first place, it has no keel formed hy the mion of the two lower petals). It has, it is true, a hamer but represented only by a petal somewhat broacler than the rest, the other four being alike. The five stamens are clistinct from rath other, as compared with the nine or ten more or less mited stanens in other members of the family. Then the pod is very short with only one seed.

The Purple Prairie ("lover is found abundantly on dry planims and gravelly hills throughout oun territory. It is a typical dry ground plant, almost as much so as the Prairie Pink describerl and pietured on earlier pages. It has more foliage than the latter plint, lut the leaflets are narrow and the colges are robled inward to proteret the moler side of the lauves, where the broathing pores are located. Its root also is almirably adapted to withstand drought.

A white-flomered species, with somewhat hroader loaflets ambl

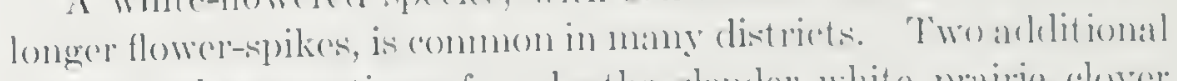
ones are also sometimes foumd the slender whito pratrie cluver and the silky prairic clover. 

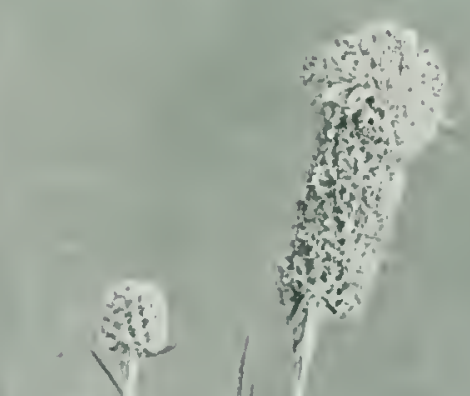

itic $\left\{\begin{array}{l}1 \\ \text { ing }\end{array}\right.$

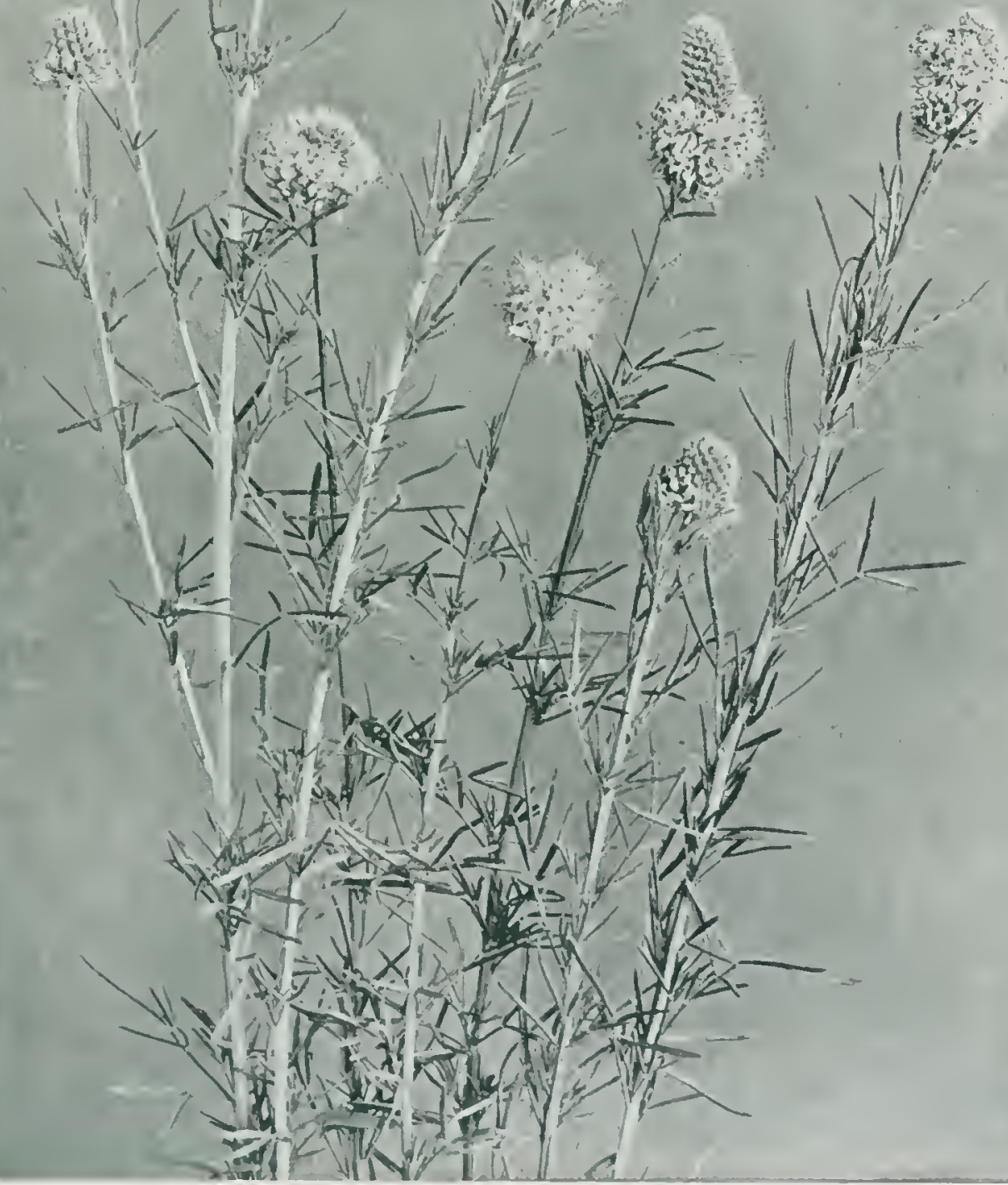

I'TRIJI: I'R.TIRIS ( 'LOVER 


\section{NORTHERN HEDYSARUM}

Iterlysarum boreale Niutt.

Pre PANIS

The Northern Hedysarum is a native of the northern and western part of the Continent. Common among thickets, along roadsides, and on the plains, it is, over wide areas, guite the most abundant nember of its family.

The picture shows it greatly reduced in size, as the plants photographed were more than two fect tall. The hoight, howerer, varies from one to three feet. The rather stout stems hear pinnate leaves, having from eleven to twenty-one leaflets. From the axils of the upper leaves spring long racemes of mumerous pale pink, rose, or purple flowers. Athongh the stems are stiff, the drooping blossoms and light foliage lend an air of eleganee and grace to the plant. The drooping flowers are suceeded by drooping pods. As these are prominently jointed, they serve as a ready means of identifieation.

Several other species of Hedysarm oeene in 17 estern Camalat As none of them seem to have yet been given a common name, they must be referred to by their botanical nimes. H. sulphureseens closely resembles the one described abore hut has sulphur-yellow flowers, and is fommd chicfly in the momntains and foothills. $/ 1$. cinerasens, with redelish-purple flowers and silvery leaves, is fommel in elry soil on the prarie. H. Mactenzii, the nost showy one of all, is common in the moatows of the foothills and astwarel in the southern part of the prarie legion. On rivor hanks it secoms also to le spreating far to the bist and North. Its mannere of growth- lustorexl stems, eight to cighteen inches high, forming a roumber mass of bright guren foliage topped with elusters of large flower's of a virid rose-purplerenclers it one of the most striking and handsone of our wild plants. 


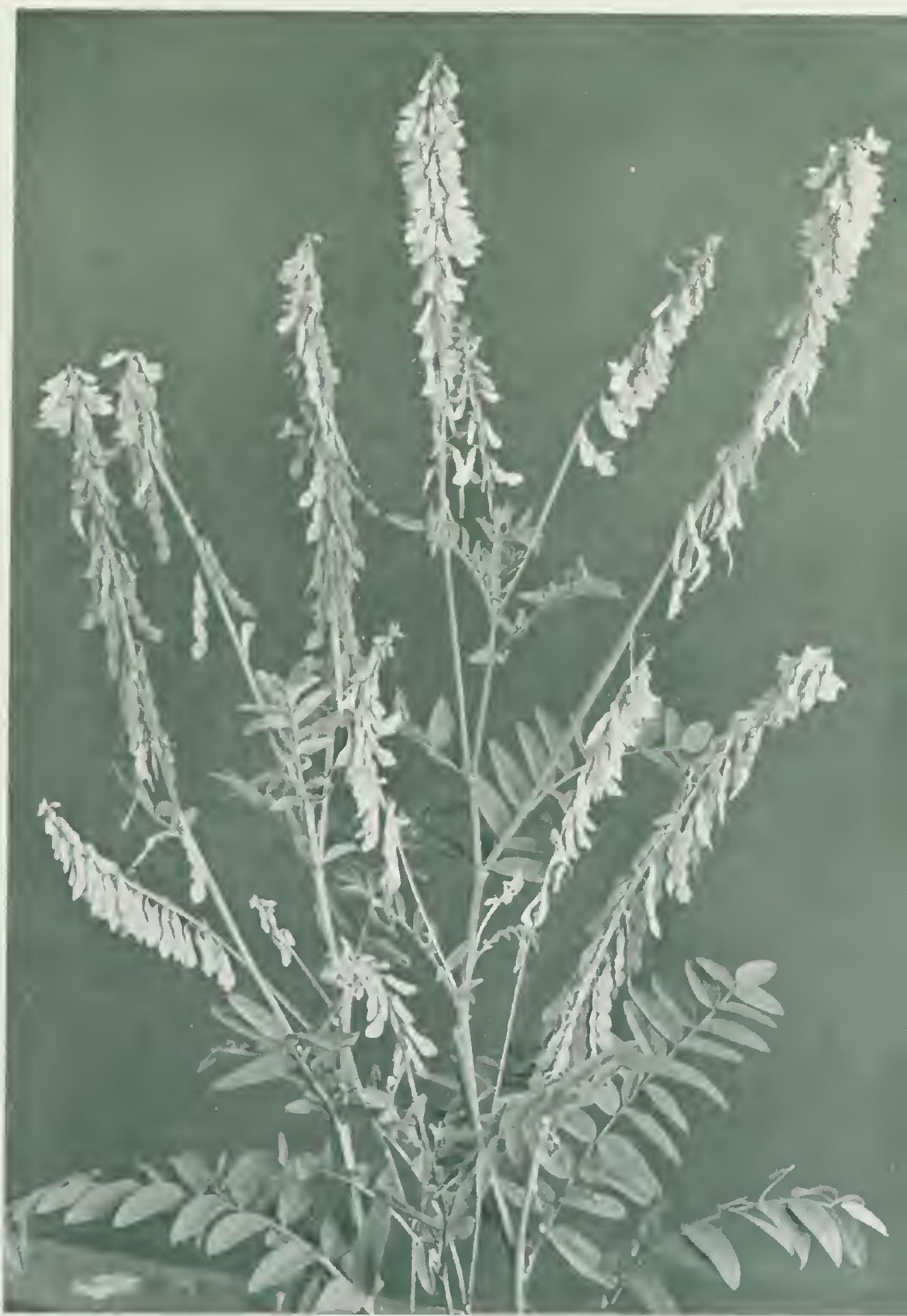

NorTHERN HIDYSIRIM 


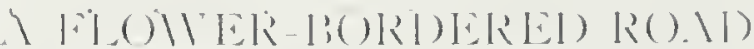

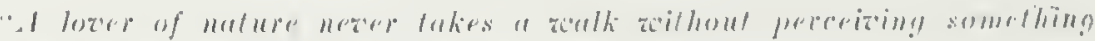

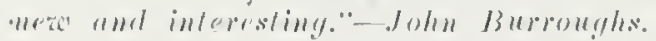

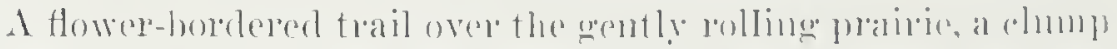
or two of poplases or willows, orephead the dece blue sky anel the

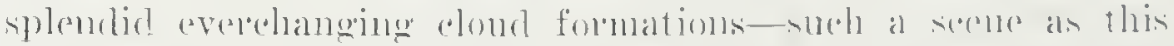

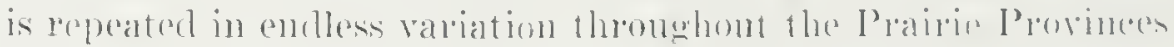
dn10ing the summoner nonths.

A list of the roadsiele flowers womld be too long for this page. They form a lovely natulal ablendar, givine to the oberorant

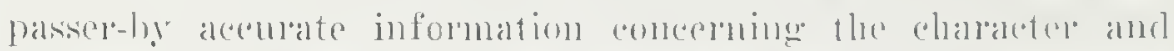

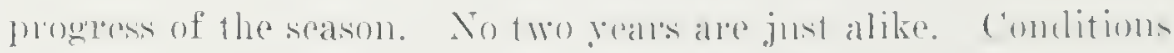

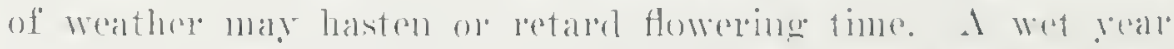
favors the moisture-loving plants and they make a remalkable

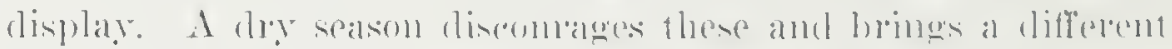

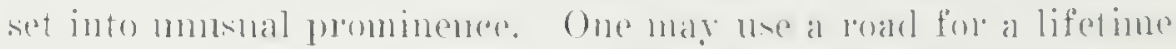
alud still each gear will show some new Horal foature.

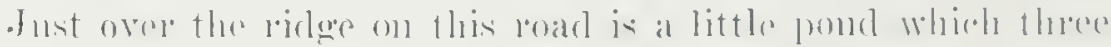

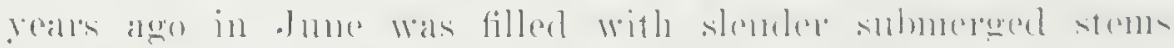

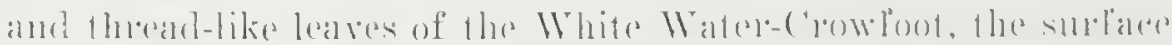

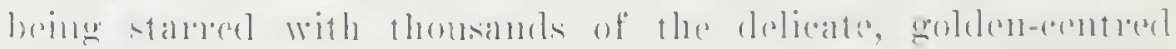

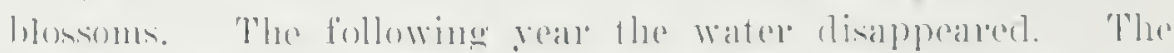

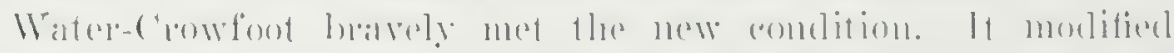

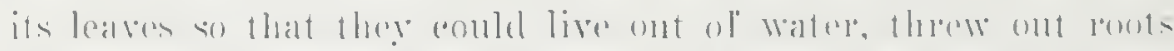

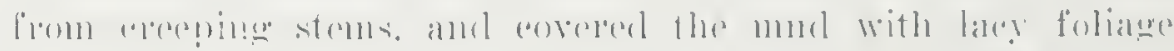

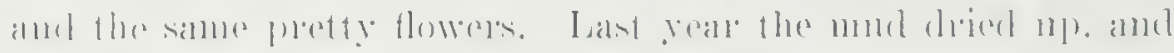

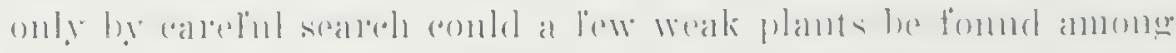

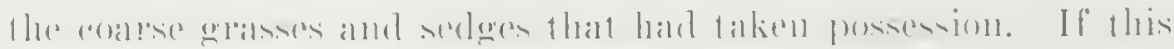

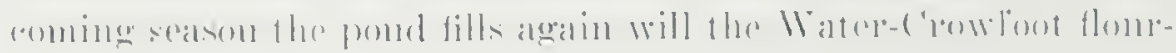
isli als hoforen?

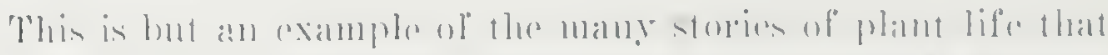

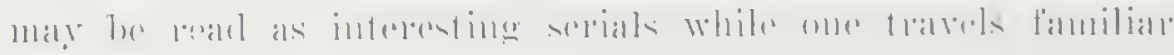
roilis. 


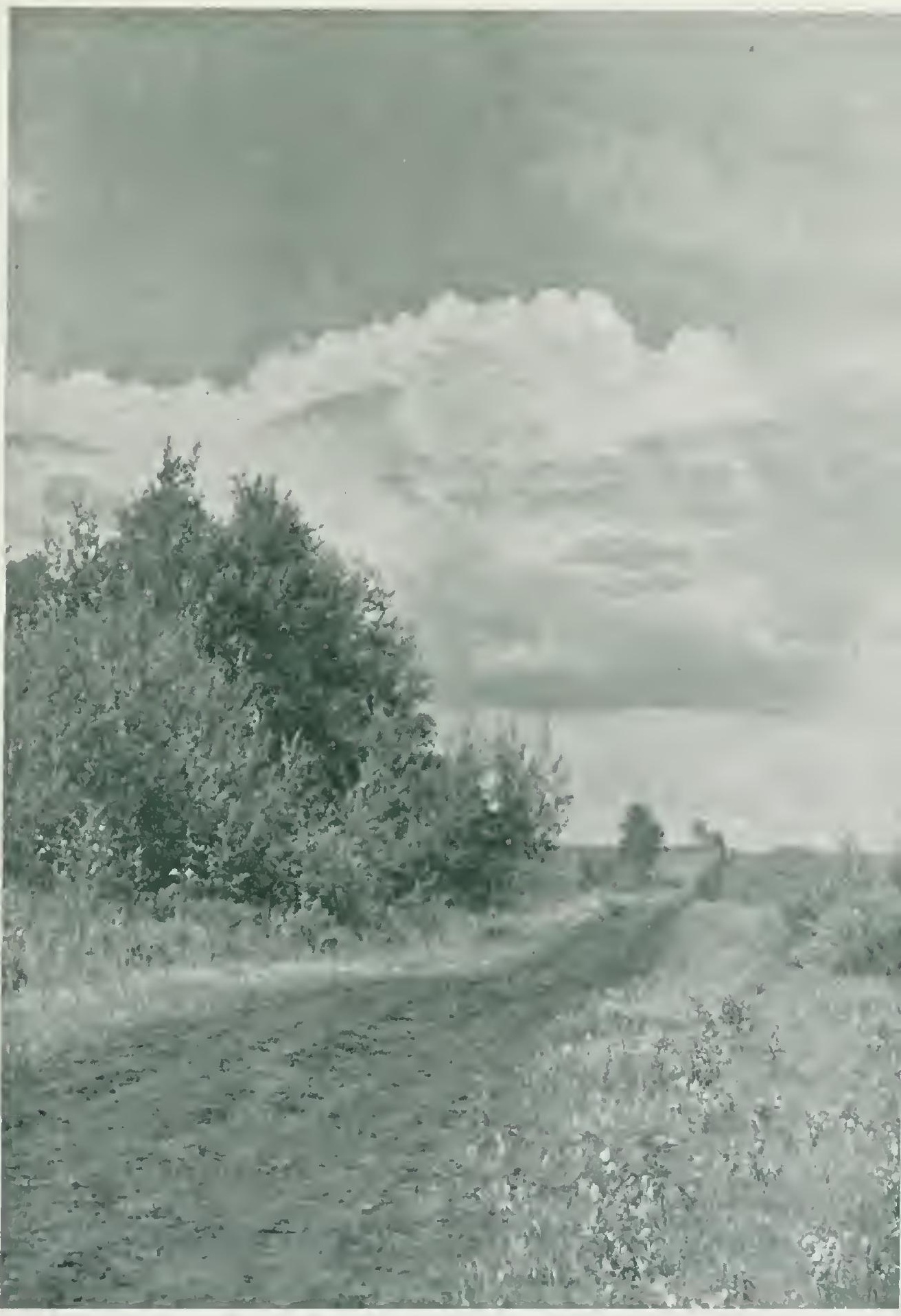

A FIOWER-IBORDIERED ROAD 


\section{IIEH) NE NETTLE}

\section{stluchys pulustriss l.}

\section{MINT FANII}

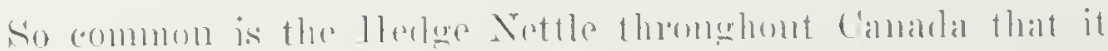

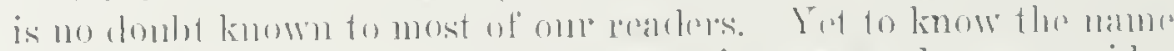

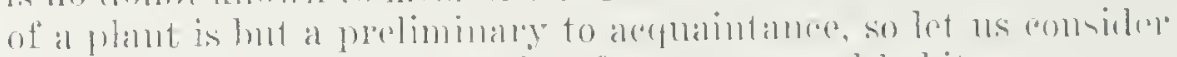
this plant in some of its details of stroneture allol hablit.

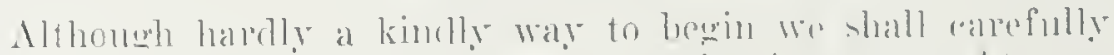

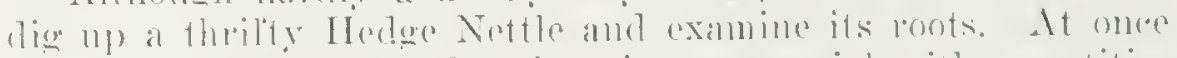
it will he notiond that the plant is a peremoial with fountitien

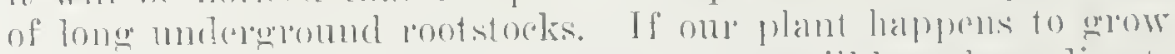

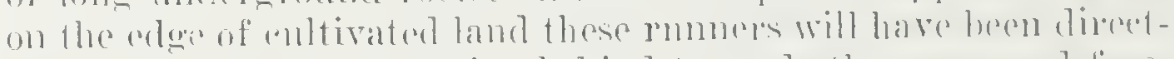

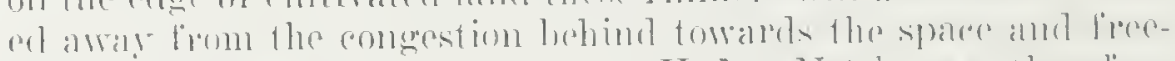

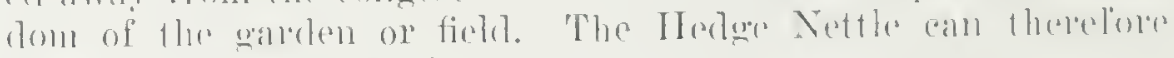
laver foward opportmity.

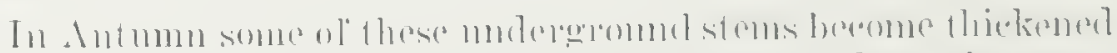

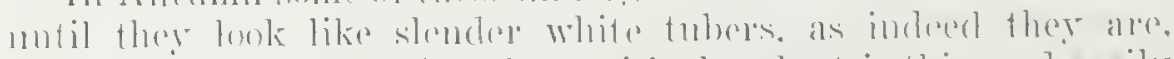
for the portion commeding them with the plant is thin and ansly boken, and, if these rosisp tubers be taken amb plantert like

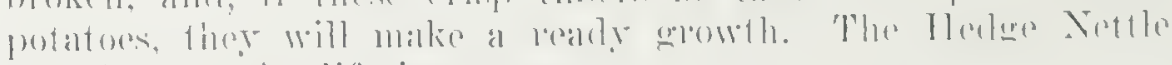

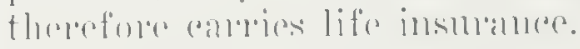

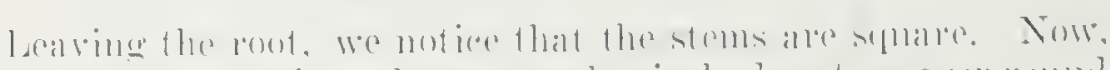

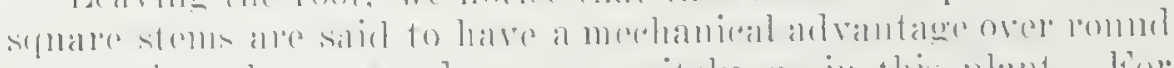

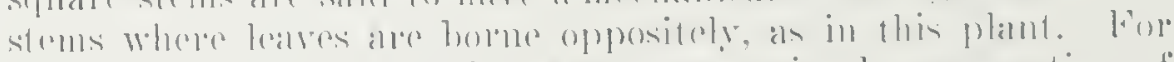

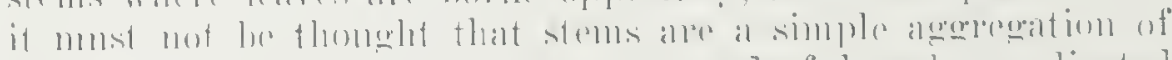

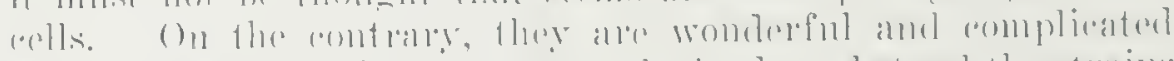

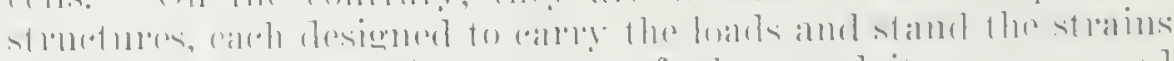

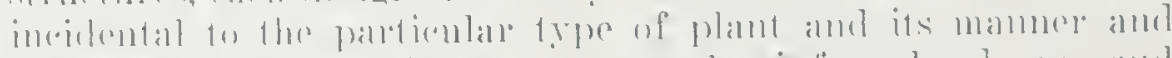

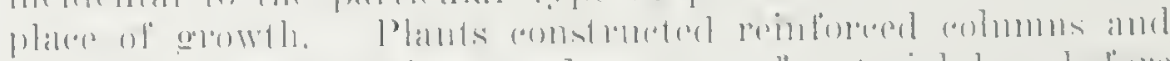

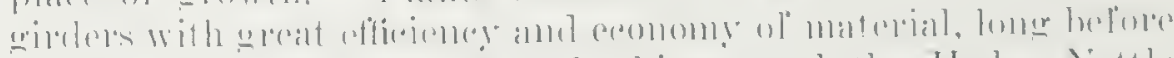

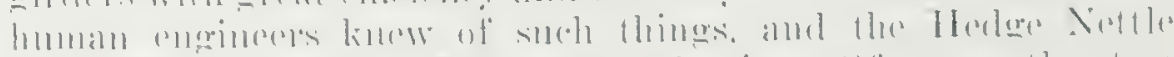

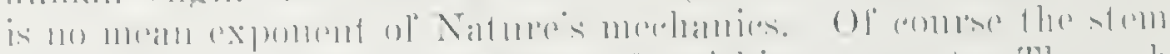

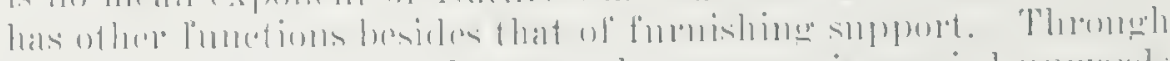

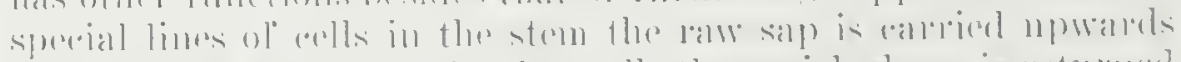

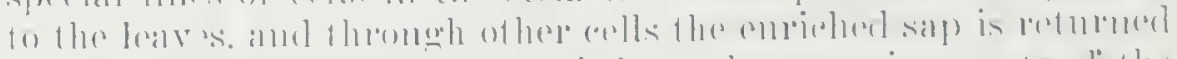

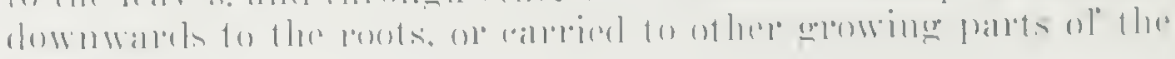
plill1.

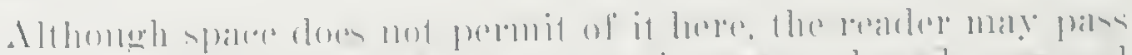

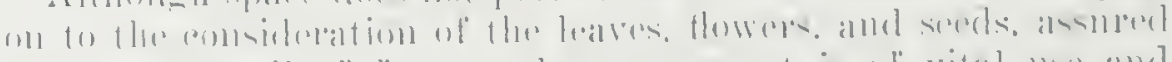

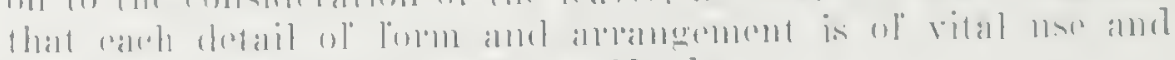

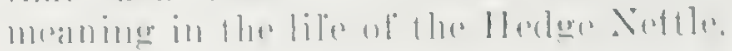




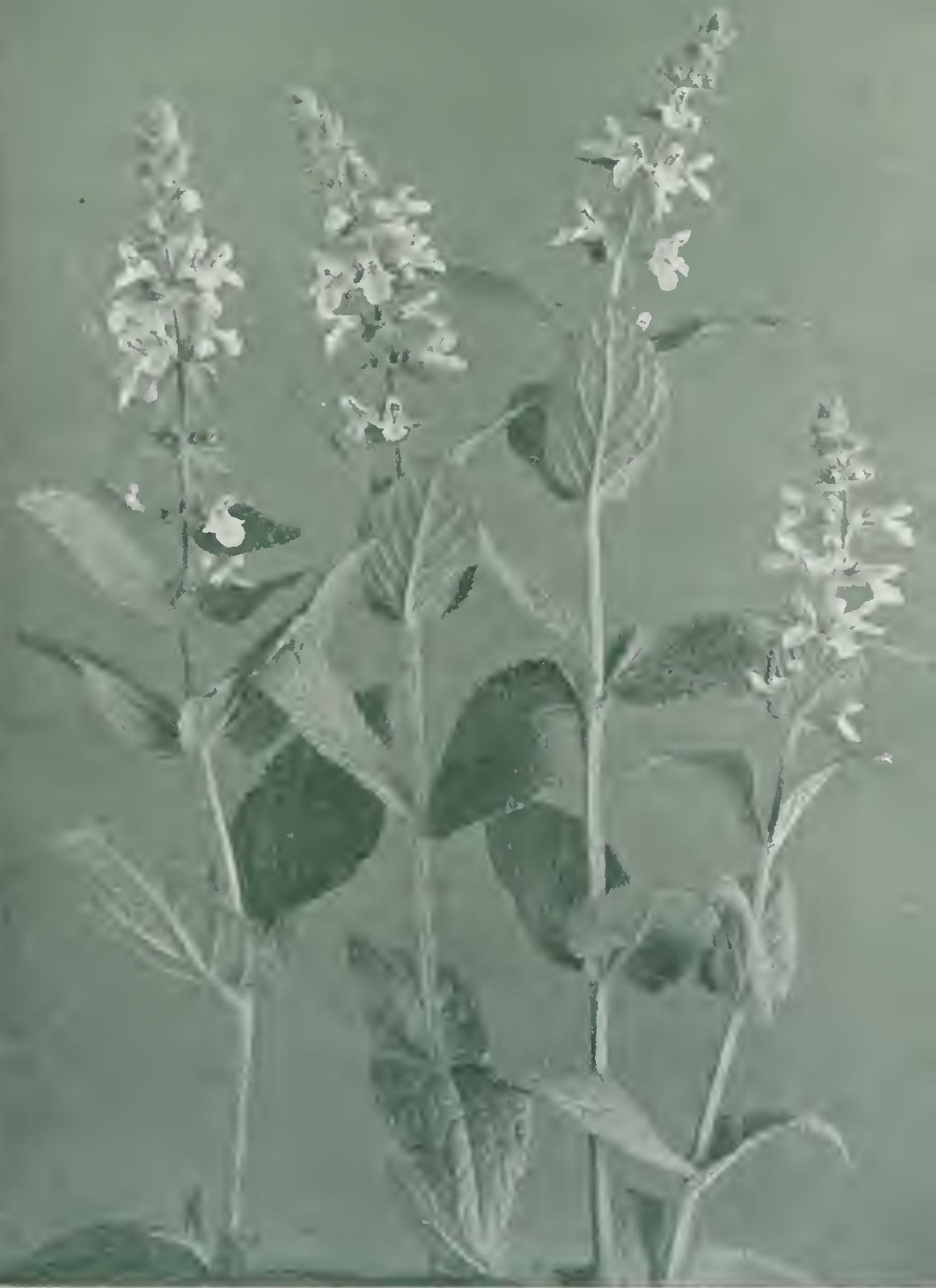

HFuck: NetTI F 


\section{GREAT-FLOWERED GAILLARDIA}

Ciaillardia aristata P'ursh

ThIstLe FAMIIYY

This Gaillardia, perhaps the handsomest nember of the Sunflower tribe, is a native of the western hills and plains. Whilst found over a wide area, it is most abundant in the southern part of our territory. It prefers sandy and gravelly soil an l rejoices in full exposure to sumshine. Its graceful form and its wonclerful coloring have attracted the attention of horticulturists, so that today one may find it in the best laid out garlens everywhere.

The stems, one or two feet high, are gray-green hy reason of their hairy covering, as are also the leaves. The flower-heacls, carried singly on long stalks, are from two to four inches in diameter. At first the lisk is flat and light green, but soon after shows an outer ring of lark red. As the florets open, the outer ones first, this red ring spreacls in ward, its progress being marked by the projection of successive rings of yellow anthers. Finally, the green buds having all opened, the whole disk becomes redelishbrown, convex in shape, and heavily fringed with brown hairs. The broal, overlapping lays, notehed at the ends, are sometines entirely golelen yellow but oftener at the base are flushed dark red, and voined, especially on the mulersick, with the same color.

The whole combination of size, form, color, and texture is charming, and rests this brown-eged susin of the plains with a wealth of glowing heauty. Whon each provines romes to adopt an official flower, the Ciallarelia shomld be a camblicte for surh lonor in the Wrest. 


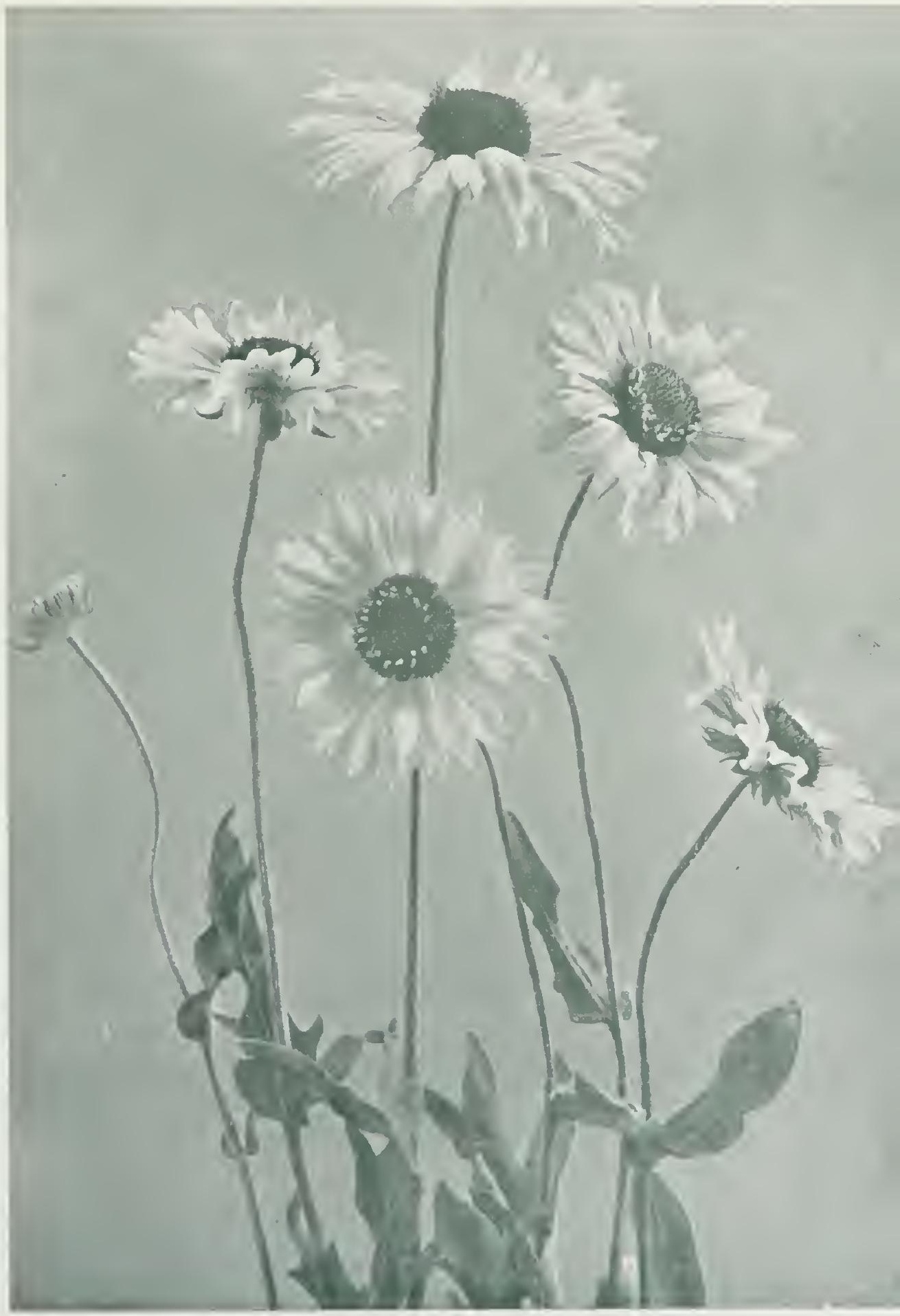

Great-Flowered Gatllardi 


\title{
TALL MEADOW RUE
}

\author{
Thatictrum purpurascens L.
}

Coowhot Fami

Growing in open wooks and thickets and along roadsides, this Meadow Rue, lifting its hig panicles of crean-colored tassels six feet high, is one of the alegant plants of late June or early July. The large but finely divided leaves resemble coarse maidenhair ferns, and, together with the fathery bloom, give an airy grace to the tall herb.

It is usually of dioecioms habit. Neither male nor female flowers have petals and the sepals are small and (hop off carly. The male chuster owes its heanty to the masses of anthers drooping on slencler filaments, and the female chester to the numerous bunches of pistils with long, glistening stigmas, which are atmirably shapeed to catch pollen as it drifts through the air.

There is here no chaborate arrangenent for sereming fertilization by insects and although they nuy sometimes le of service, chief dependence seems to be placed on the wind ats carrier. Contsequently the flowers are hede aloove smrounting vegetation, and pollon is produced lavishly to allow for the great waste resultant from this simple method.

Sometimes the protillate plants bear also a fow stamens with fertile anthers, showing that there is porhaps all andhition to reacle the higher development which would be indieated by the pro-

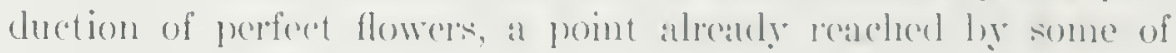
the mearlow rues.

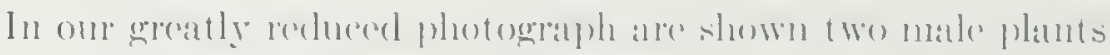
on the outside and a female in the comter. 


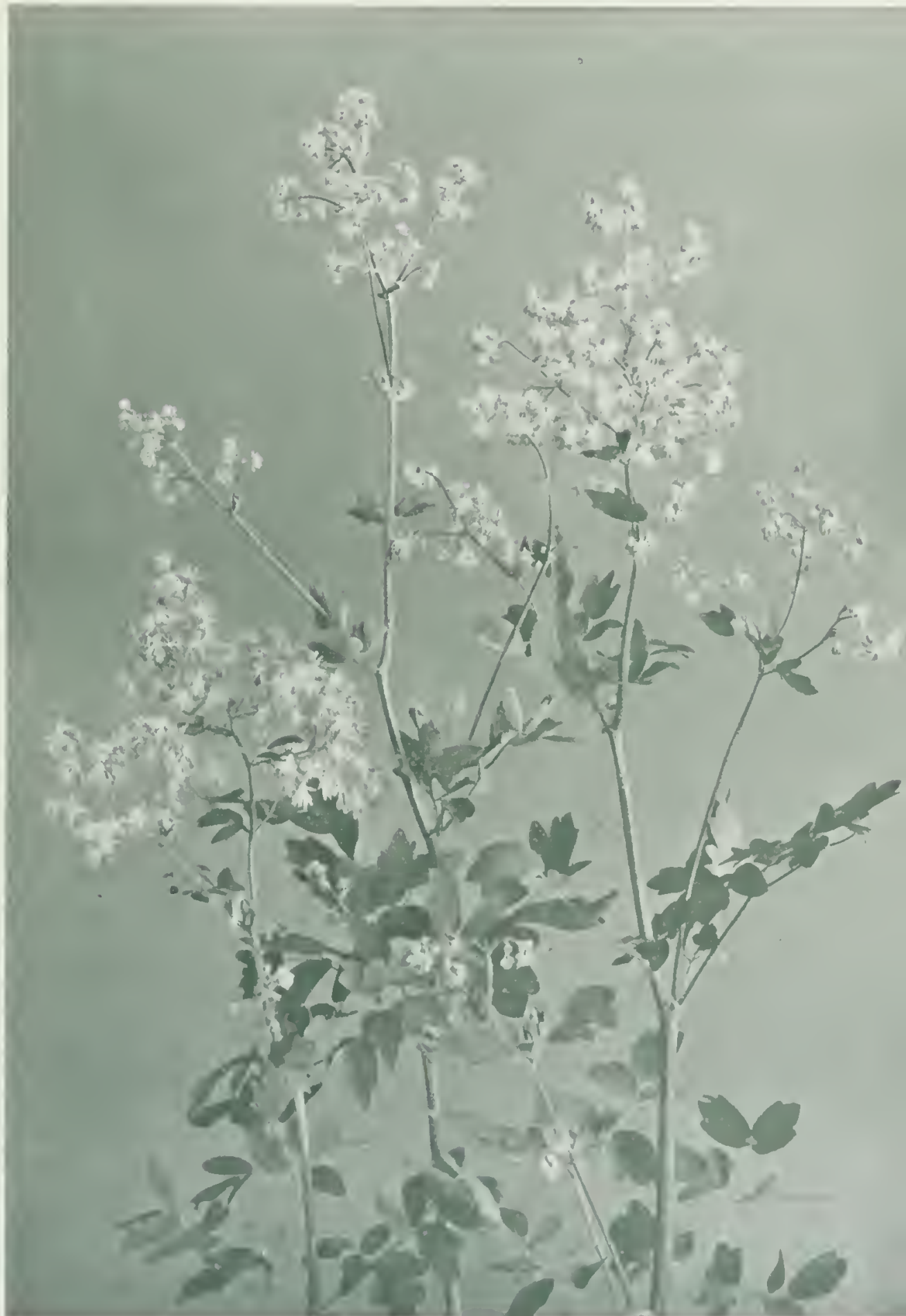

TAIL MLANOW RUE 


\section{- LOCO-WEED}

\section{Oxytropis Lamberti Pursh}

Pea FamL Y

The Loco-weed, although well-known in Wrestern Canacka, is notorious rather than renowned. Its bad reputation is due to its poisonous effects when eaten by sheep, cattle, and horses, causing them to stagger in their gait, to walk in circles, and otherwise behave as no well-regulated animals should. Fomotimes the death of the afflicted animals results. Yot there scems to be some mystery about the plant, for over certain wide areas where it grows one scarcely ever hears of a case of loco-poisoning, while other parts of the country report such an occurrence frequently.

The Loco-weed exhibits great variation also in form ancl color, both among individuals in the same locality, and among the types found in different localities. Onr picture gives a general idea of the aspect of the plant-clustered leaves and flower-stalks springing from a deep root, both leaves and stalkis more or less gray with silky hairs, and many pea-shaped blossoms borne in spikes. Frequently, however, the spikes are denser and shorter than those shown opposite, and, insteat of light eream-colored flowers such as this plant produced, the bloom may be purpte or reddish-purple.

Although "beauty is what beauty does" the boeo-weed is a pretty plant, and it has several handsome relatives. Foremost of these is the Showy Oxytrope found commonly on dry prairies from Manitoba to the Rockies. It may be distinguished from the Loco-weed by its more hairy leaves, which are so chensely covered with long silvery hairs as to appear white; by its leaflets which are borne in bunches of three to five instead of singly; and by its more showy rose-purple flowers which are arranged in more narrow and clongated spikes. Inderel, the showy ()xytrope (O. splendens) is well named, for with its shafts of bright blossoms rising from a mass of soft, shining white foliage it forms in Jume one of the most eonspienous and splendid ornancnts of the dry prairie. 


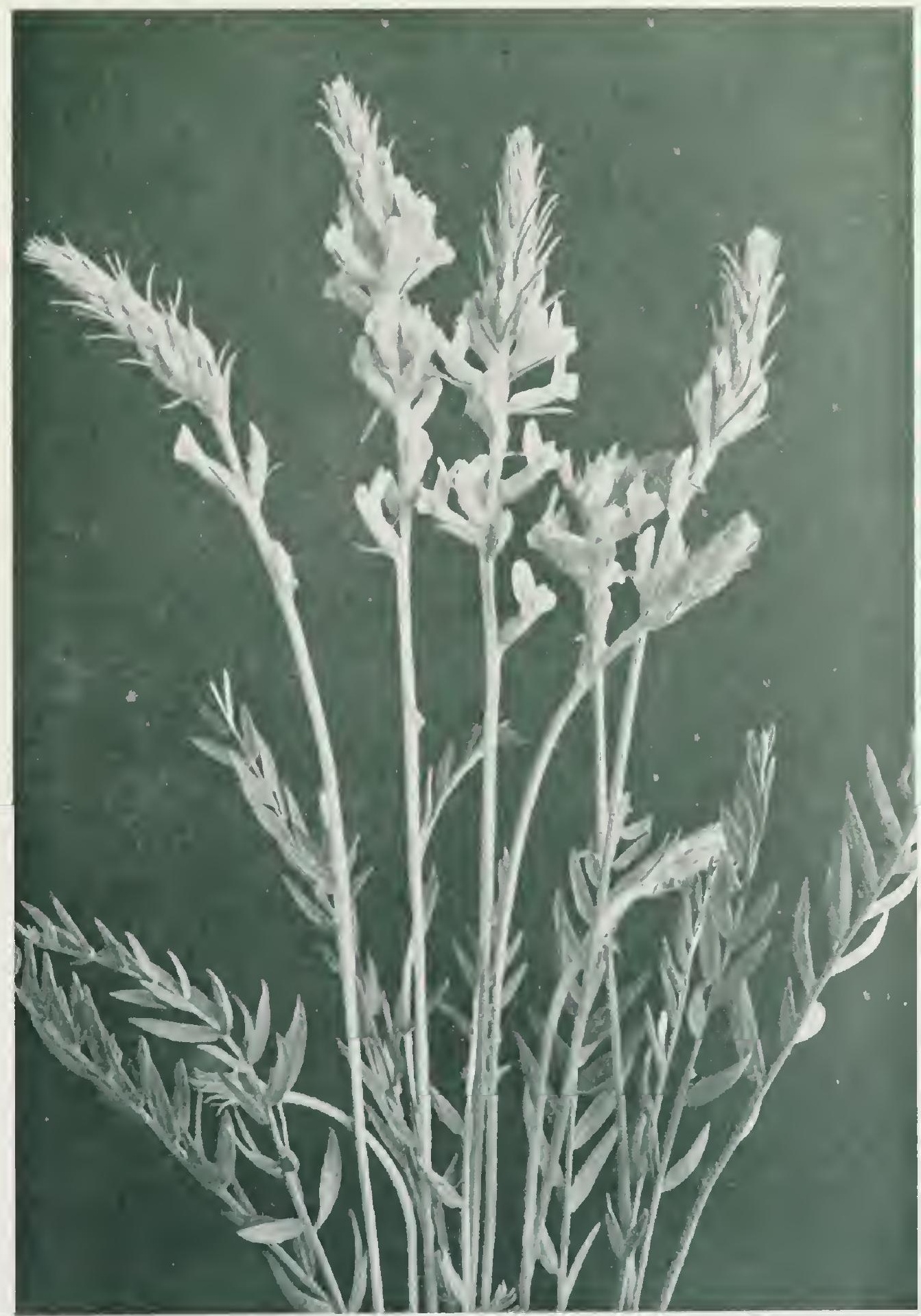

L.OCO- MEEN 


\section{Nol)H IN( \\ .lllilm intellum lioth. \\ IILI FMUIXY}

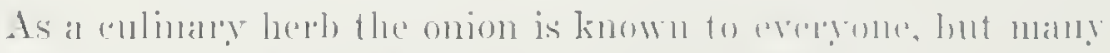
fail to reongnize in this danty and paraeful plant a member of

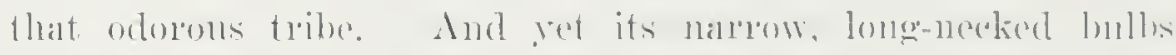

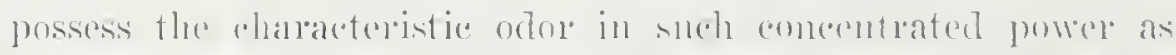

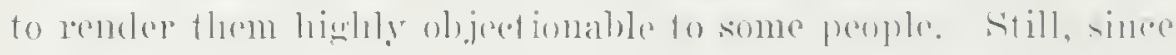
the bulbs a athination for the pretty flowers.

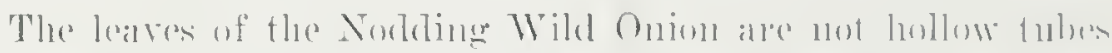

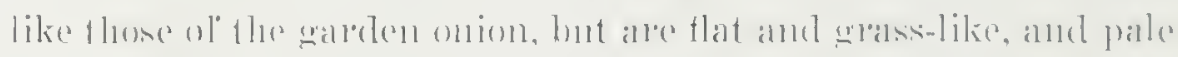

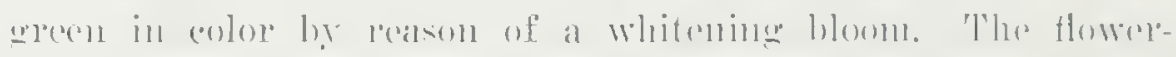

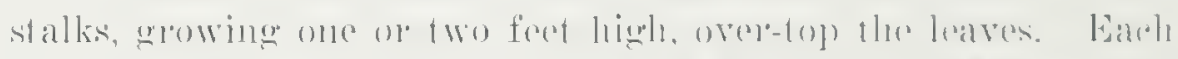

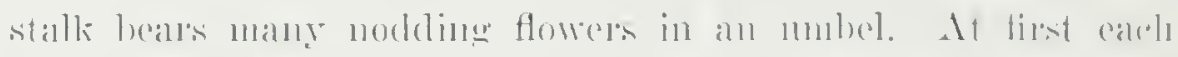

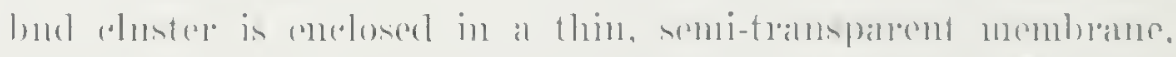

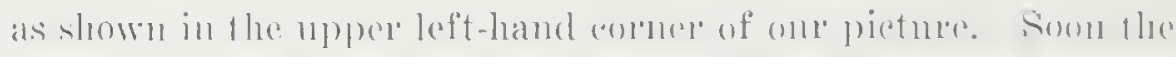

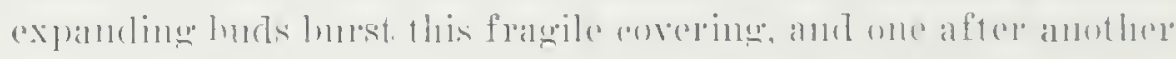
open like ting bells with six projoctines stomens. In trextme the

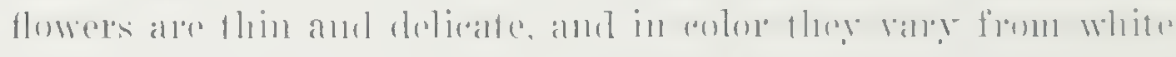

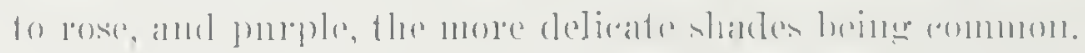

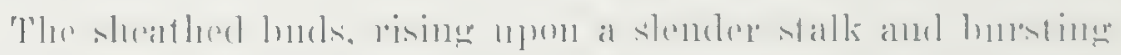

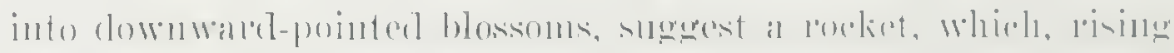

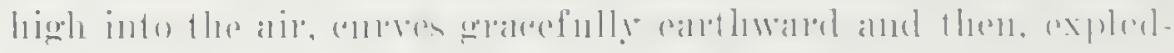

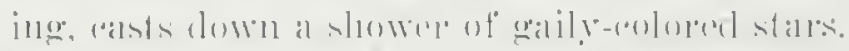

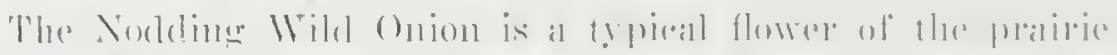

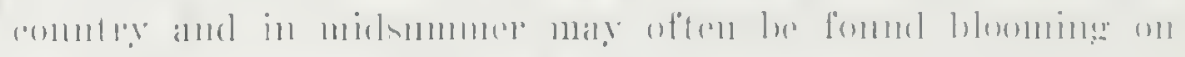

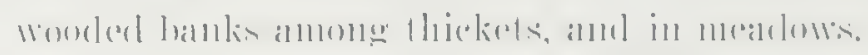




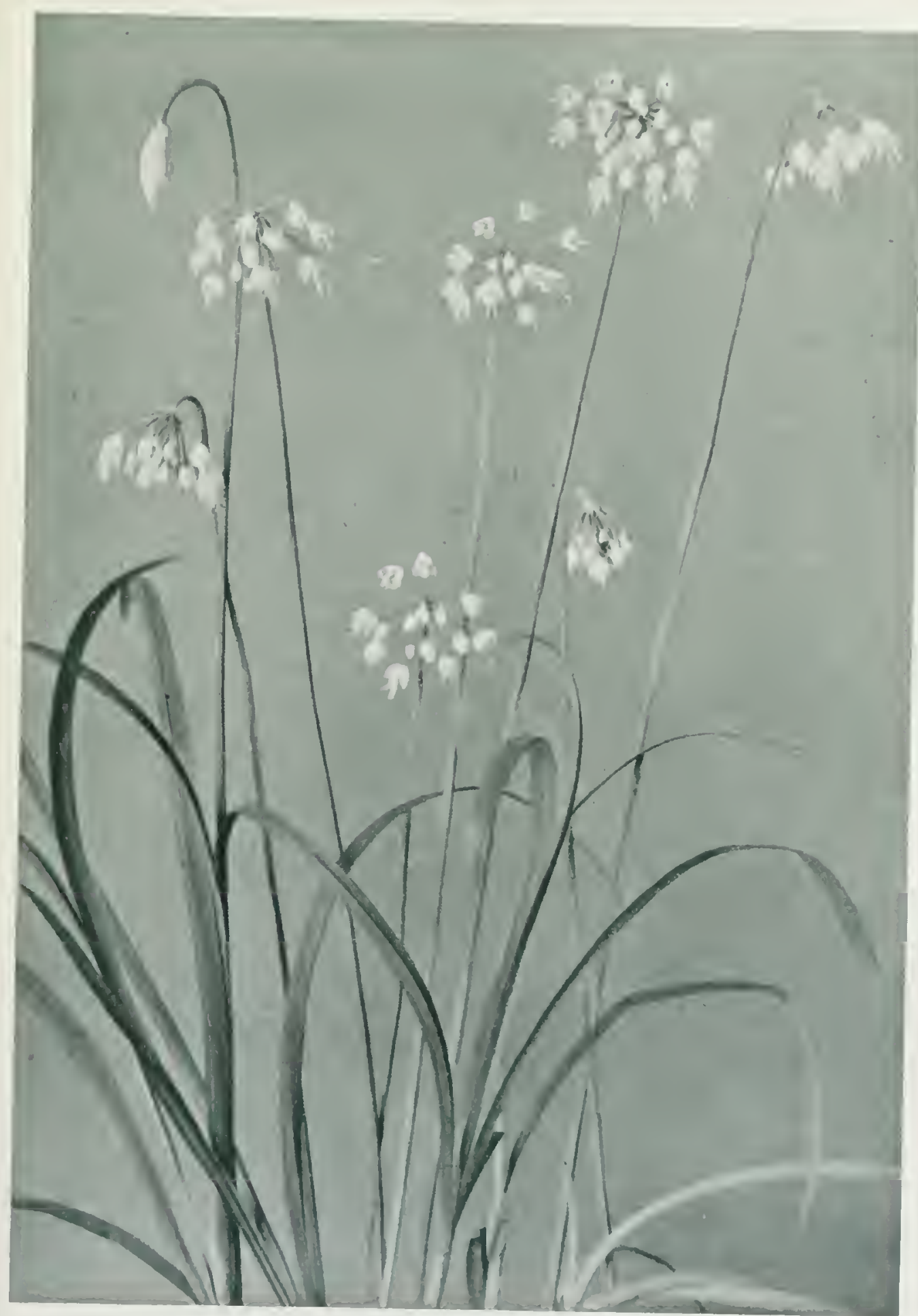

NODDING; Wil.d OnION 


\section{TALL OR GLAUCOUS ZYGADENUS; WHI'TE CAMAS}

Zygadenus clegans P'ursh

LILY FAMII,Y

This beautiful Zygadenus may frequently be foumel in wet meadows throughout the ITestern Provinees. Howerer it may occur, in scattered groups or in greater profusion, it is always in a quiet and elegant way an attractive feature of the landscape.

Springing from bulbous roots, the stems rise to a height of one to three feet. Botlustems and lauves are smooth and gluncous - whitened with a bloom. The smaller stems bear their flow's in a simple raceme, hut the stronger ones may "ary a large, open panicle of bloom a foot in length. Fach flower, ahout threequarters of an inch in dianeter, is white or grocnish-white with a large green gland, shining with a moist secretion near the batse of each of its six divisions. The three-parted pistil with the six surrounding stamens adds much to the beanty of the flower.

'This White Camas, to use another of its names, is unfortmat? in its relatives. Several relaterl species, known as Death ('amas, are so poisonous that numerous animals, especially sherp, die cach year from having eaten of them. The White (anlas is salit to have in some degree the same poisonous principle, but to be very seldom caten by stork. With the descriptions here given and the pieture shown opposite as guides to identificution 110 one merel make a nuistake. The deadly speries are smaller in size, with narower leaves which are rather goment to the touch. Moreover, the rand, so distinctive of the White (amas, is not much in evidenere in the smatler and more croweded yellow or yellowish flowers of the Dath ('mmas. 


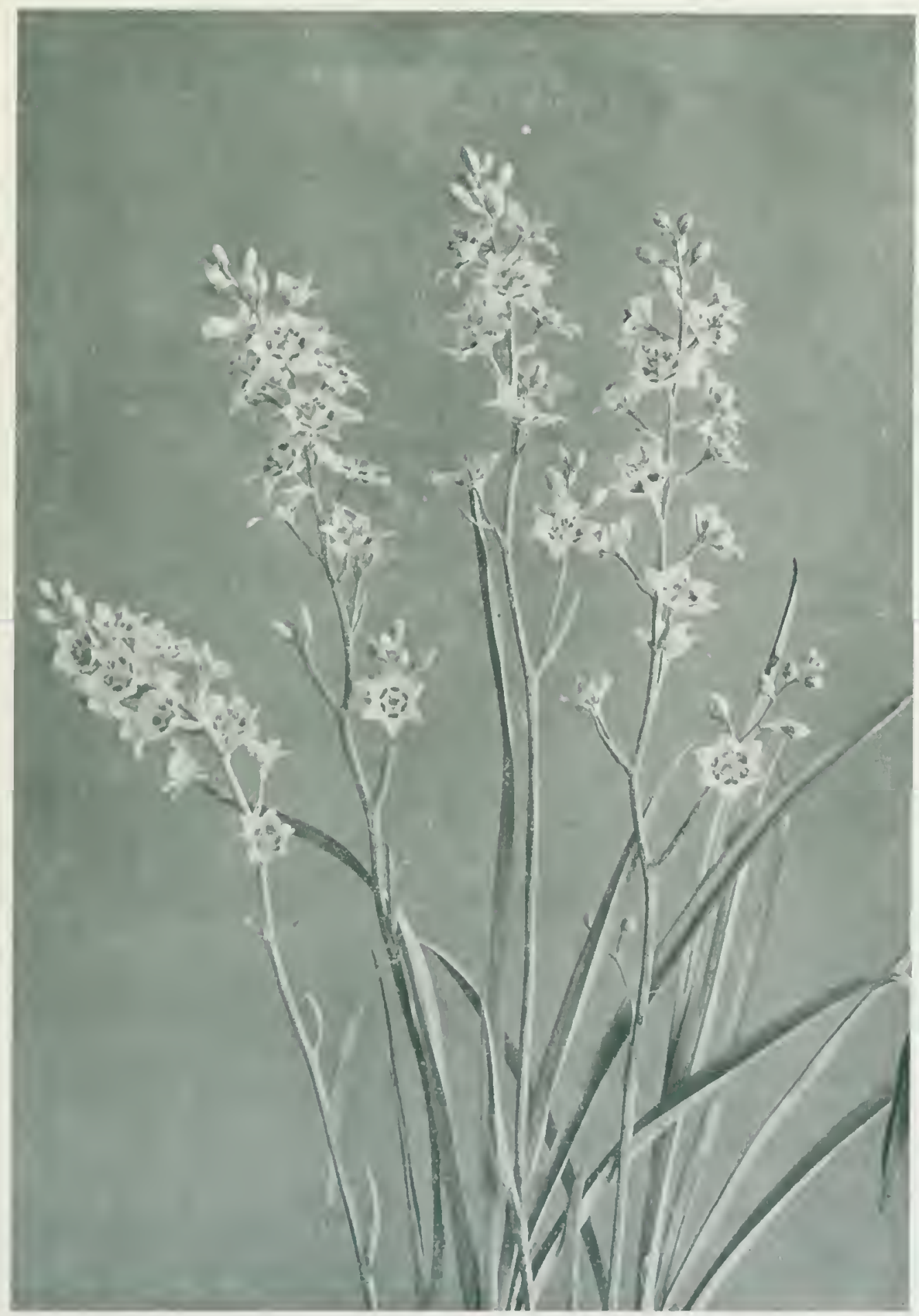

TALI OR GIATCOLS ZYGADENUS; WHTE CANAS 


\section{OУAL-LEAVED MILKUEED}

\section{Asclepias ovatifolia Inec.}

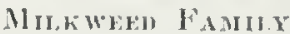

A flower of such marked individnality as the milliweres, once seen in life or in picture, is asily reeomized thereafter. For

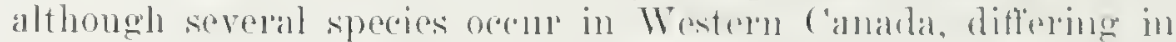
color ane in many details, the nuigure flewereform eommon to all, sets them apart from otlere plants.

'The Oval-leared Milkweed is probalyly the anmmonest western species, wrowing in rich, well-drained soil, either in full sumsline or among bushes, from Manitolo to AHelta. Its stalks are from six to eighteen incles high, its leaves, especially on the mulerside, are soft-downy, and its greenish-white flowern, somes times tinted with purple, are horme in soft nmbelled rlusters.

Ant now to a claser study of these mentily and rorionsly former flowers. In adelition to the alvix, anel a eorolla witle five reflexed lobes, there is in the centre of the flower al fire-lober strueture happily named the arown. But when the botanist sperdis of each lothe of the crown as a hook, and the hood as hearinger a hom, and the horm an having a tooth on cithere side, it hergins to grow confusing. Still, these foatnes may lu seren fairly wall in

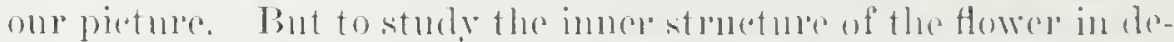
tail is impossiblo here. Suffies it to say that the pollen is problued in mimte paired masies, eateh pair commested hy a lind of alip.

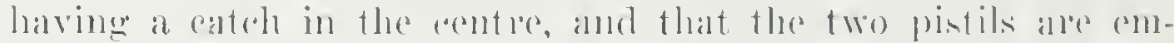
bedeled in a flestly eolumm. 'The problem of the plant is to bring the pollen masses of one ftower into contalet with the stigmals at

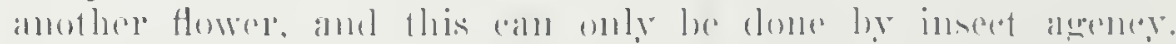

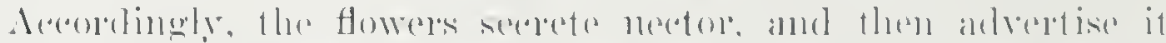

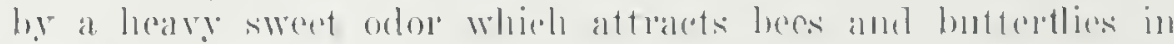

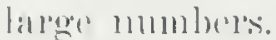

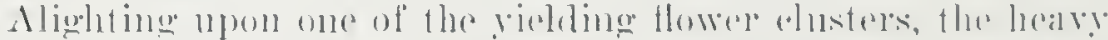

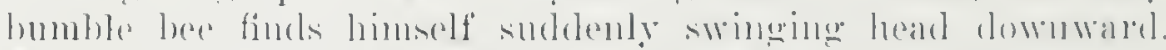

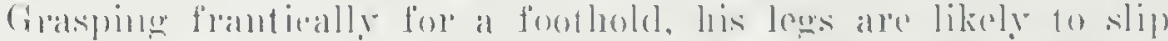

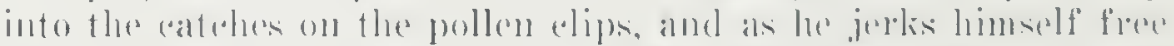

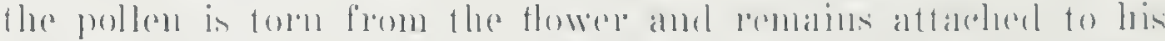

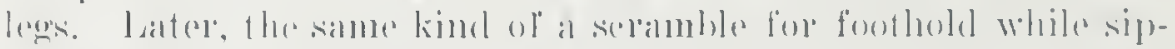

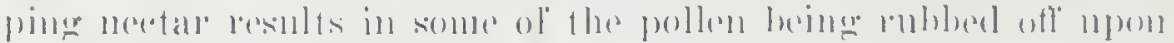
the stimmise of othere flowers.

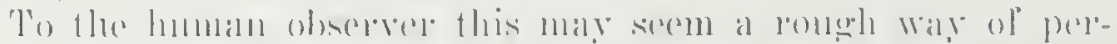

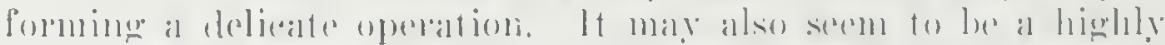

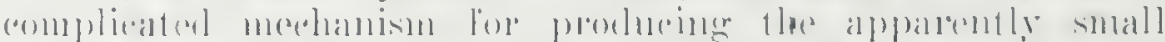

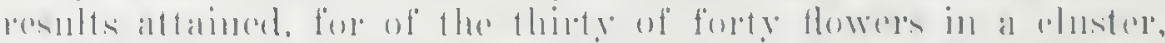

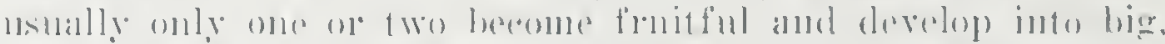

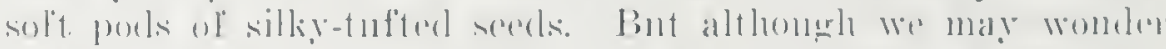

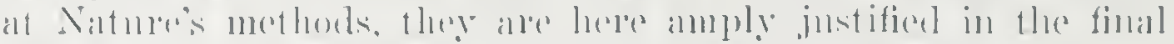

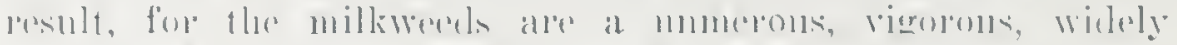

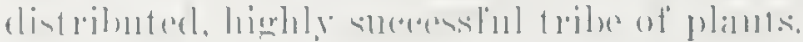




\section{$\sin , \ldots, 0$}

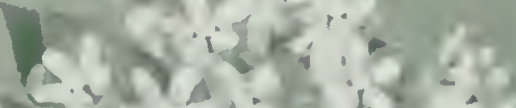

ity (2)
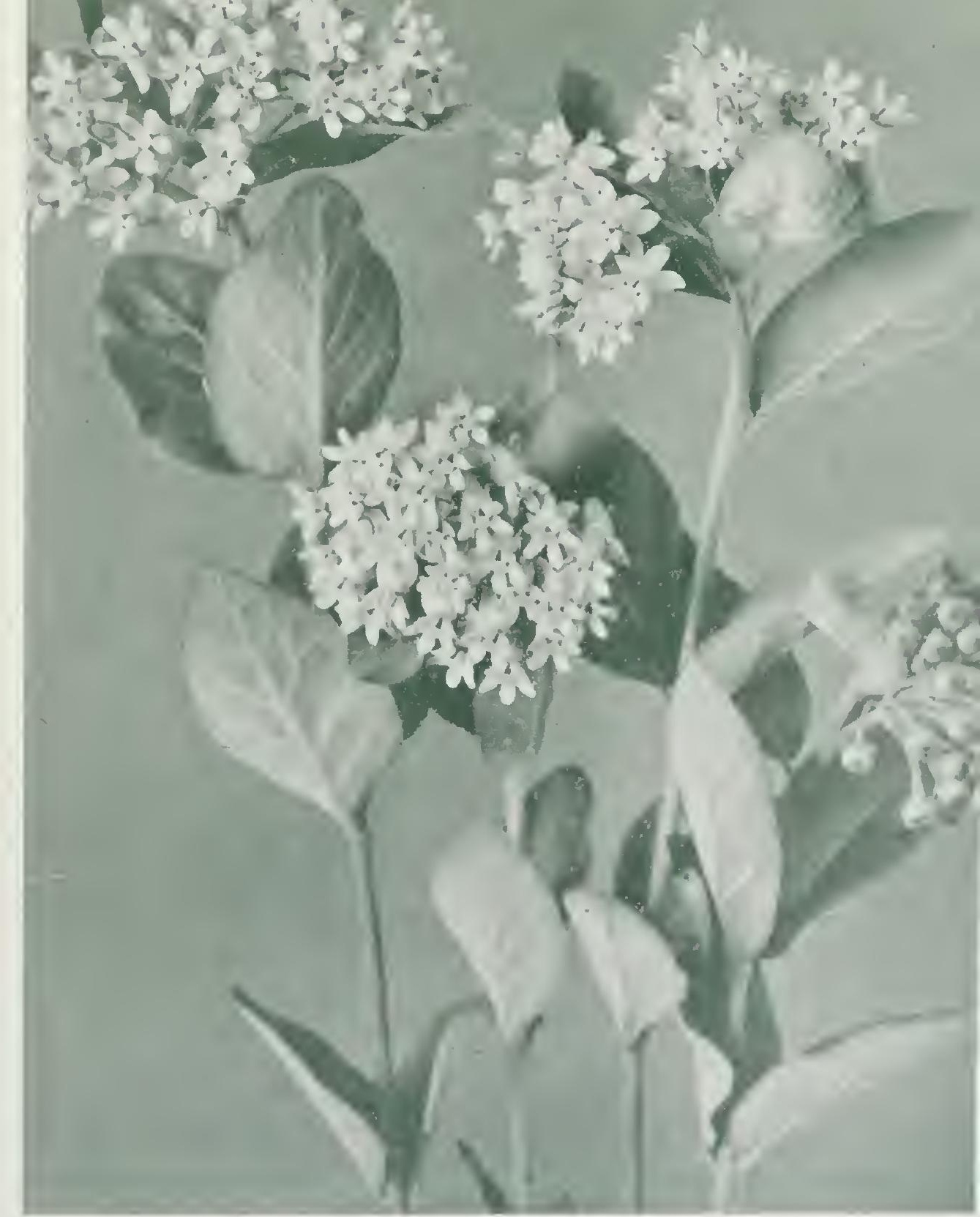

()พ.AI-I I:AVT:L) MII, WHED 


\section{ROUGH FLEABANE DAISY}

Erigeron glabellus Nutt.

'THethe Famiry

Fleabane daisies are extremely common in Western America. In Rydberg's Flora one liundred species are described, of which probably one-third are found in Canada. A number of these. however, grow only in the mountains.

The Erigerons are often mistaken for Asters. Without going into botanical details, it may be said that the former bloom in June and July, the latter in August and September. Also, the Erigerons have smaller and much more numerous disk florets, and narrower and more numerous ray florets than the Asters. This may bo seen in the picture opposite, where the close firm disk, made up of a multitude of tiny florets, is encircled by a thick fringe of fine rays numbering one hundred or one hundred and fifty.

The Rough Fleabane grows in dry soil and is common on the prairic. Its stems are from five to fiften inches high. They and the leaves are usually somewhat rough to the touch, although hardly rough enough to justify the common name of the species. The flower-hearls on ach stem are few in number, but, as the stems are clustered, the flowers make a prety show among the grass. Their disks are yellow, and their rays blue, purple, mauve, or occasionally nearly white.

An earlicr-flowering species is so abundant and showy that it must have at least a few words of deseription. It is the lhiladelphia Fleabanc, with upright stems, usually from two feet to three and one-half feet high, each carrying many pink or lavender flowers. Unlike the Rough likabane, this speceies loves wet gromul. ()ne may often sce stretches of low land brightened by its myriat blositoms, or with even greater pleasure one's ryes may trace the winding course of a brook through a meatlow, by the bands of these gay flowers along its margins. 


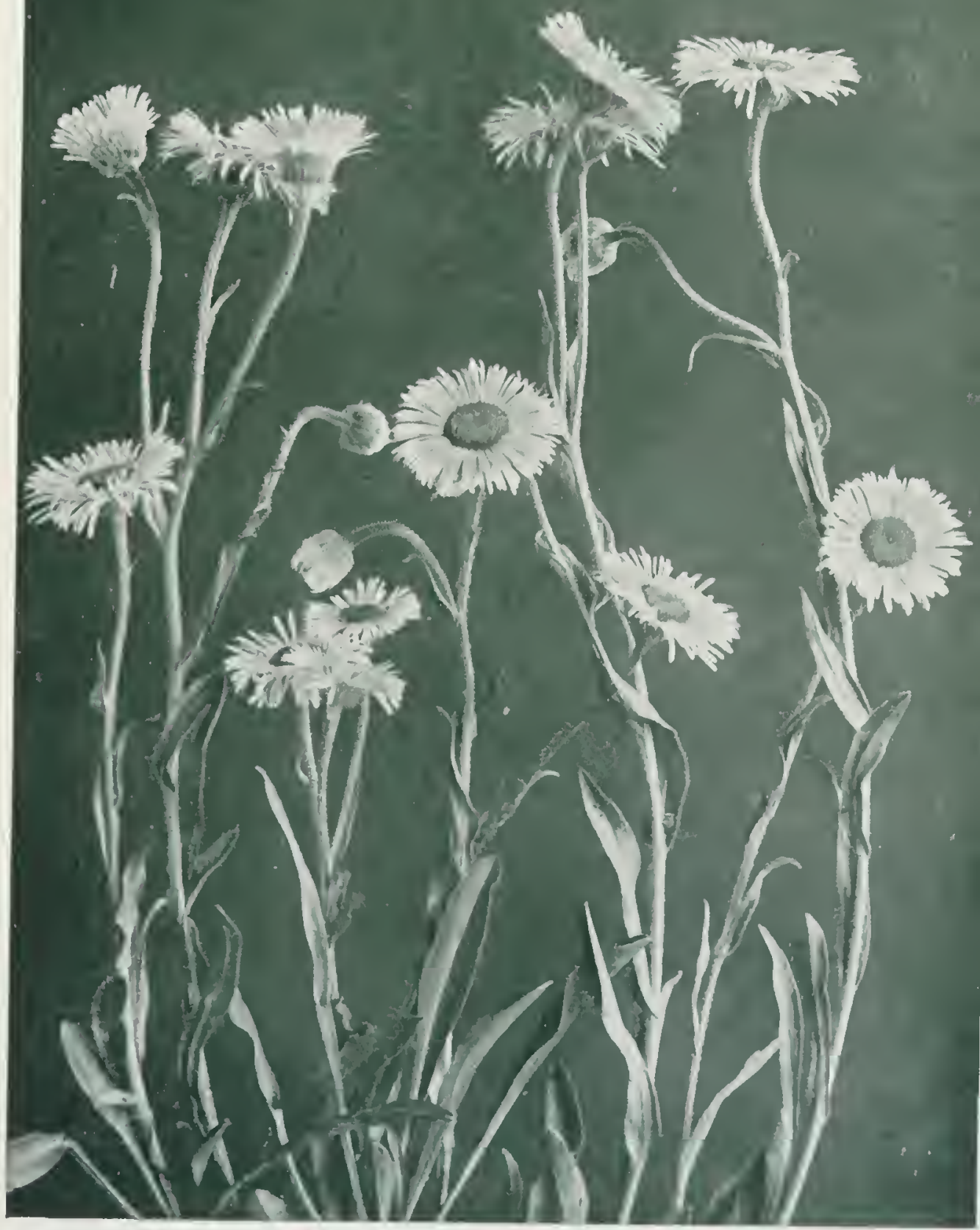

ROUGH FLEABANE DAISY 


\section{WILD BERGAMOT}

Monarda mollis $L$.

MINT FAMLL

- This is a handsome member of the aromatic Mint fanily, growing in abumelance on the prairie, along roadsicles, and anong open thickets. The stems are one to two-iunl-a-laalf feet high, bear gray-green, soft-hairy leaves, and are crowned in midsummer by rosy-pink or lilac flowers in dense clusters. These open from the centre outward. The long, narrow, upper lip of the corolla stands erect, the lower and broader lip is curved downward, as are also the buds, both being covered with soft hairs and slowing delicate gralation in color from nearly white to purple. The combination of form, texture, and color throughout the entire plant is in quiet, but elegant, taste.

Unlike the eastern Bergamot many flowers are open at once, so that the head is full and fluffy. This fulness of flower-head, or length of spike, is noticable in many plants of IVestern Canada. The phenomenon is due to the coolness of the nighlits, to frequent summer showers, and to the moisture-holding power of the black prairie soil. In an unusually hot and dry season, the individual flowers fate more guickly and the richness of the flomal display is climinished. 


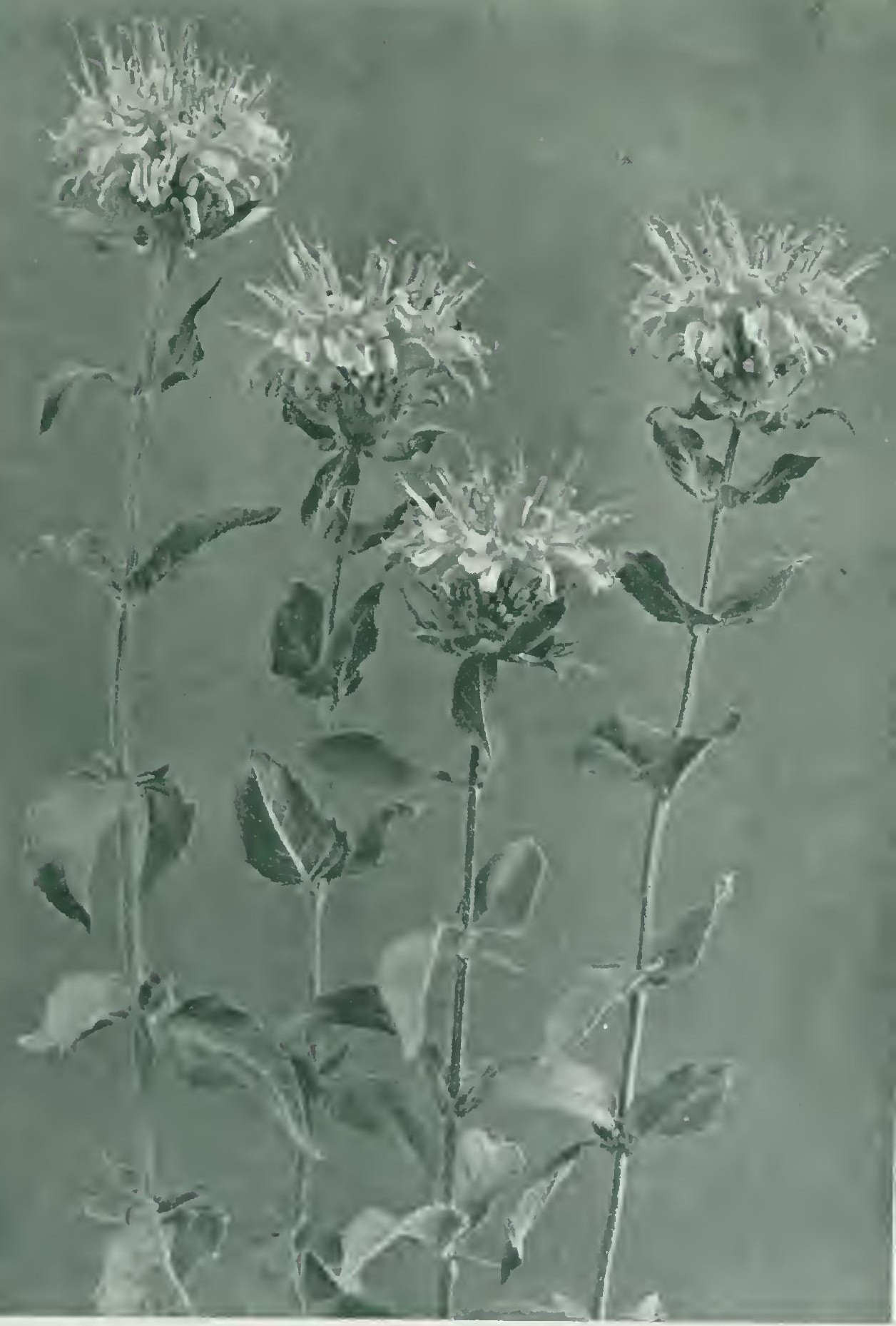

(III I) BFRGAMOT 


\section{A FERNI DEIT.}

\section{A Coxgexial Praxt Sochet}

Tho diseover stueh a ferm-filled wombland as this would be

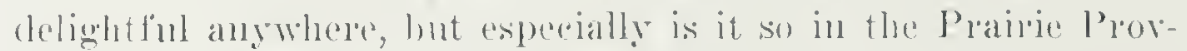
inees, where, owing to the molerate lainfall and dry air, ferms are not as much in evidence as in the moistere parts of Eastorn ('anada and British Columbia. It has heen stated that ferris ale not found anywhe in the prairie region even where trees and brush abound. Such a statement orerstates a tenderey, sinee our pieture, taken in prairie country, is evidene't that huxuriant beds

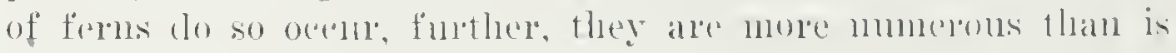
(o)mmonly believed.

'They do not of eonlese oceur on the dry, open plains. Shathe and moisture are necessiry for this Ostrich Ferm, as it is called, with its great fronds three to six feet high. But such farouble conditions are fomel in wet woods and thediets, spereblly alone streans, and from Nowfomdland to British Cohmubia, one

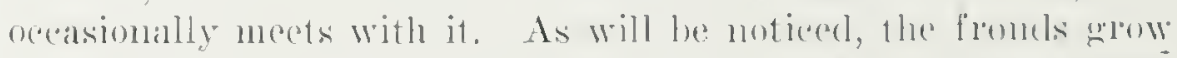

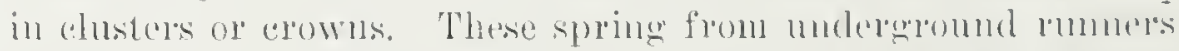
sent ont the previous season by the older rootstocks. Hence. whro the plant finds a smitable habitation, an extensive mass of lovely foliago is soon formerel.

Feros do not, like the Howeroing plants. produre serels, hut

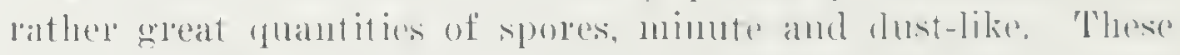

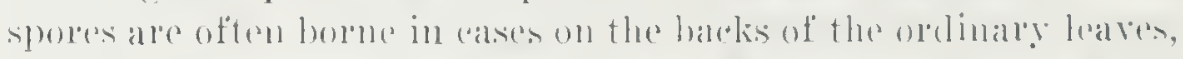

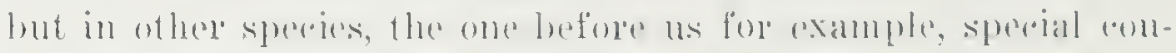

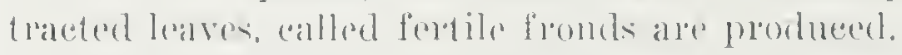

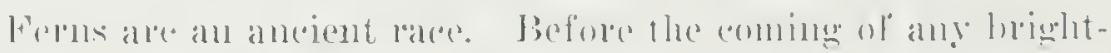

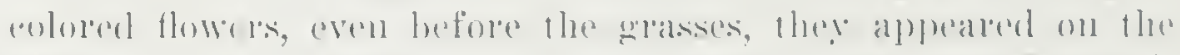

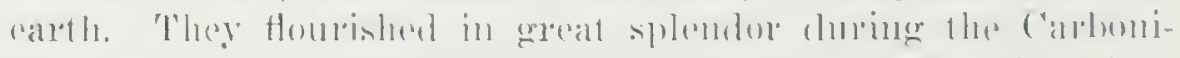

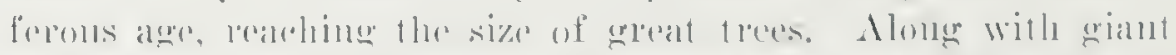

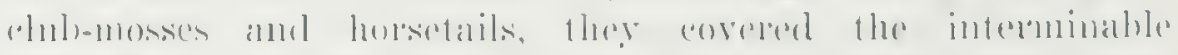

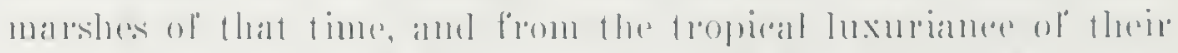

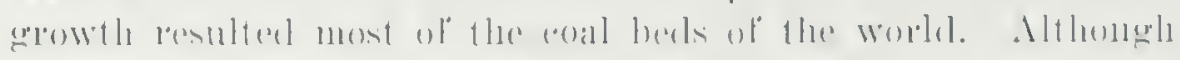

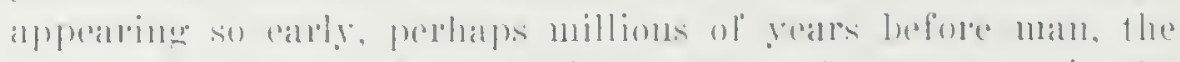

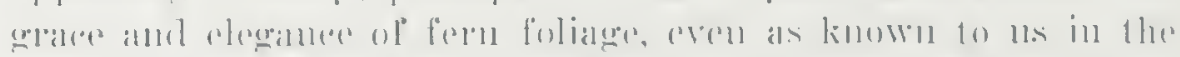

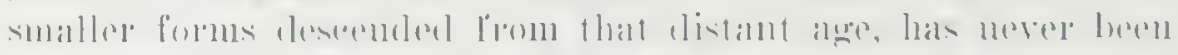

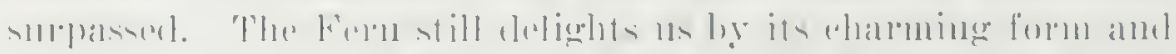

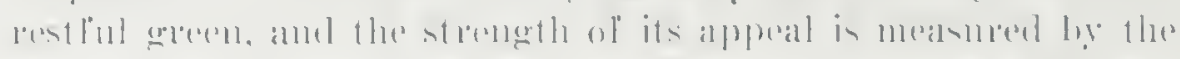

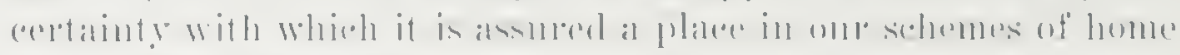

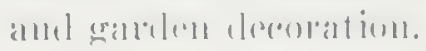




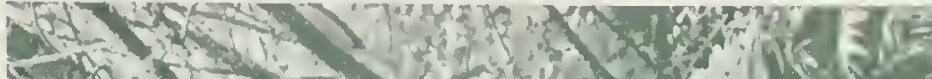

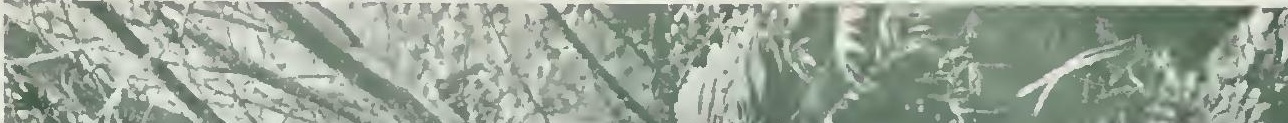
1 - -1401

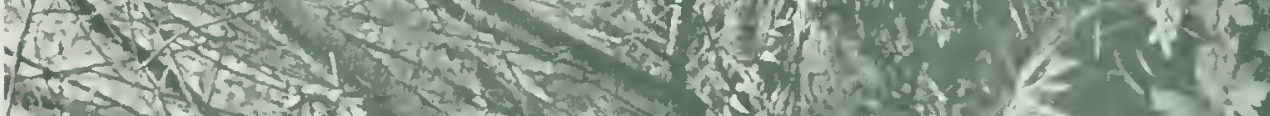

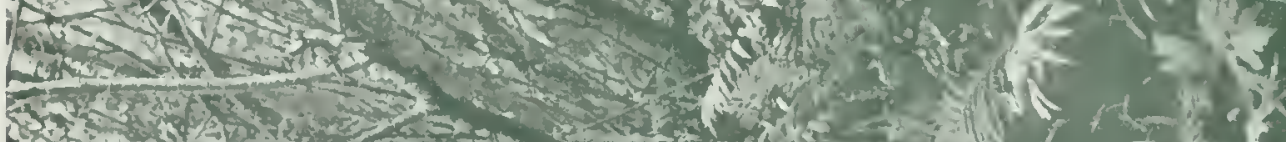
3. 20.5

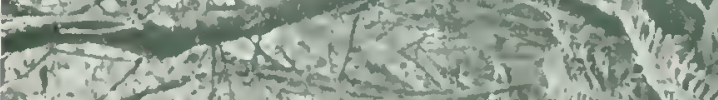

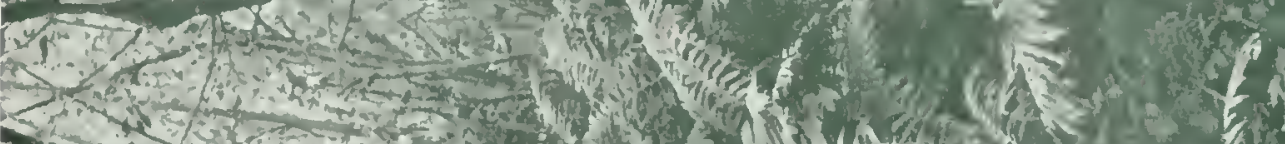

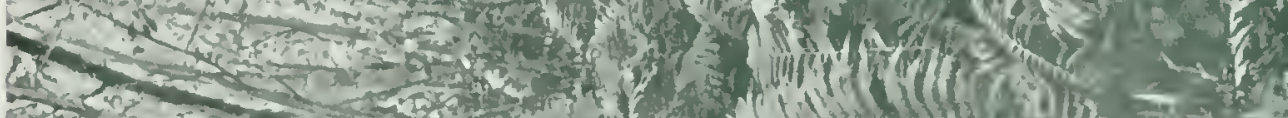
-

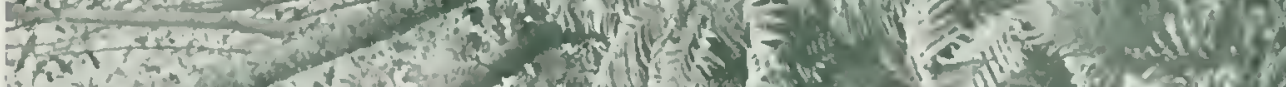

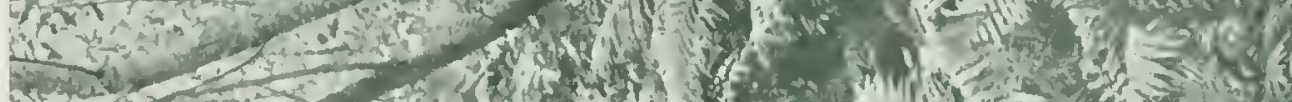
-

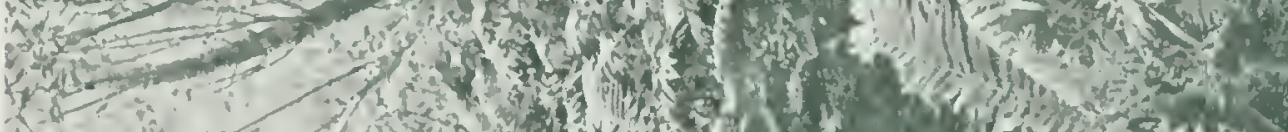

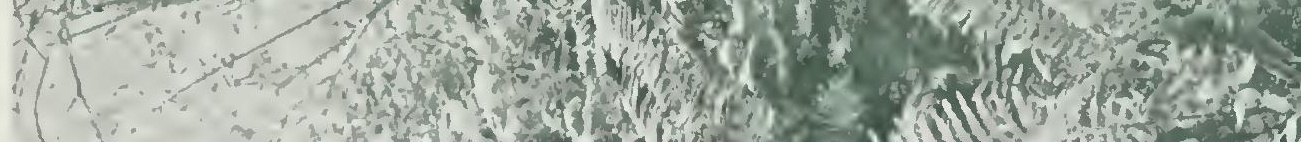

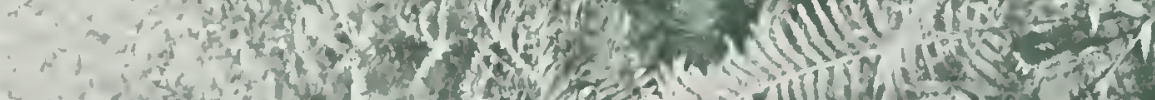
2.

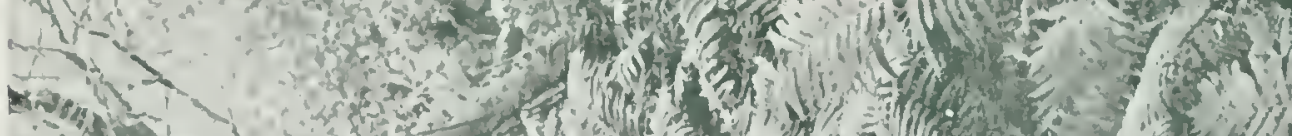
a

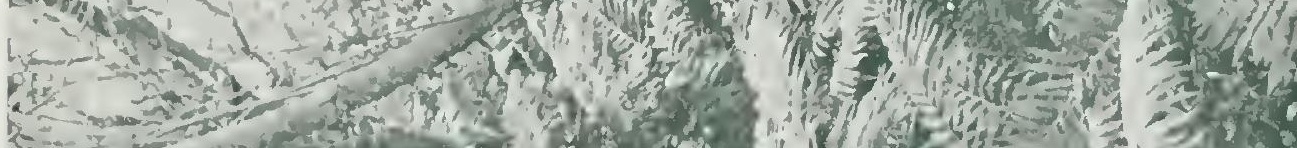

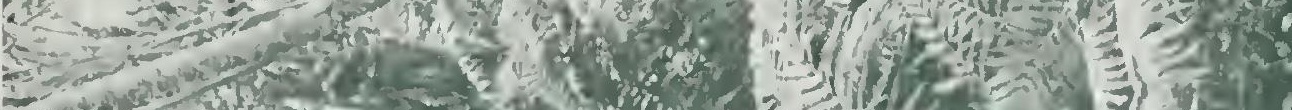

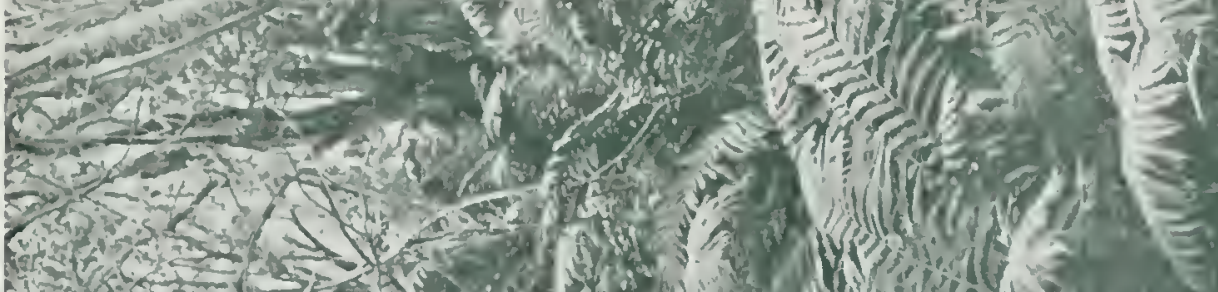

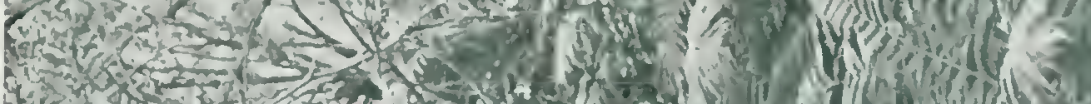

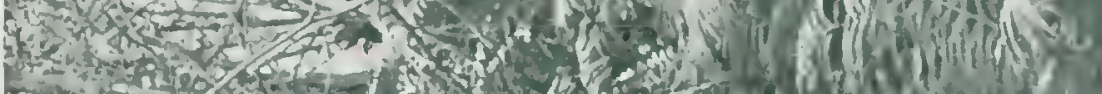
- that

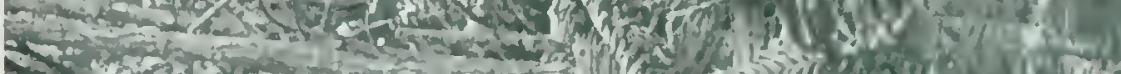

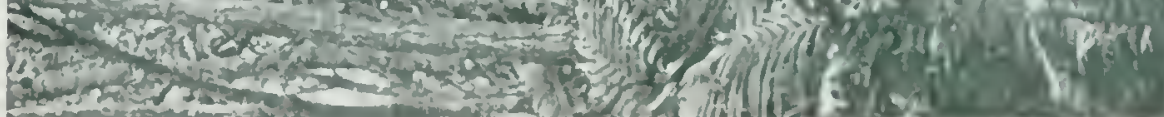




\section{Epilobium angustifolium $L$.}

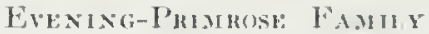

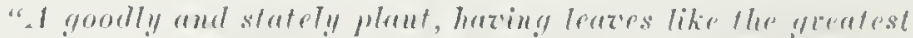

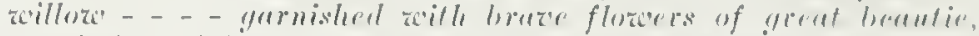
consisting of four leares apiece of an orimt purple color."

John Gireted, 15t5-161:2.

Growing to a height of there to cight feet, its strme thickly set with long, narrow, willow-like leaves, each stem topped by a lige spike-like raceme of lurght purple lotosoms, the Great Willow-herb is a striking and handsome feature of any landseape where it acoms. And its oecompence is extremely common,

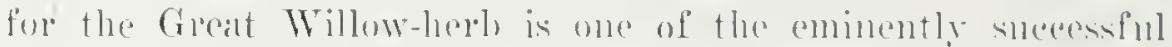
plants of the Northern Hemispherer. It suceoests hy andowinger

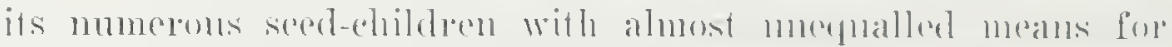

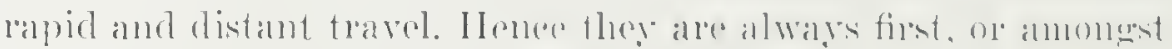

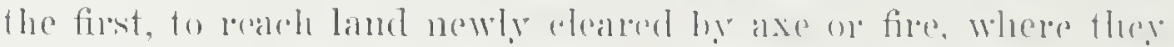

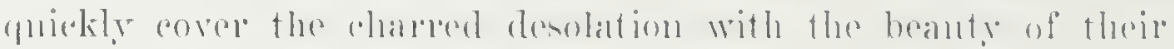
finc foliagre and hoilliant flowers.

The lower flowers on the stalk opent first, and in the ratrly period of blom the anthers ripen and shert most of their pollen. Doring this time the stele is hent down ont of the way and the lobes of thre still immatme stigma are not ret openert. Aftere

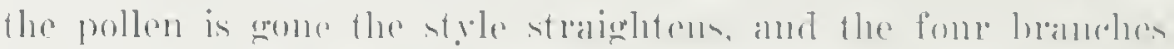

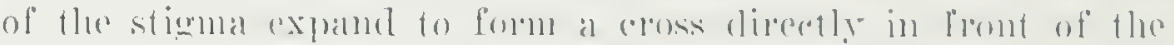

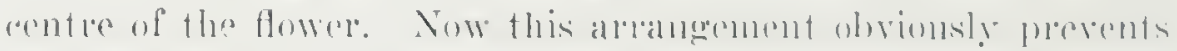

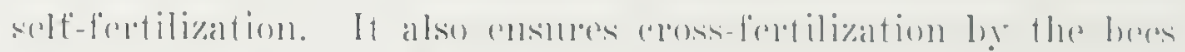
For the bees ale ro-worleres with the flowers in this mattere.

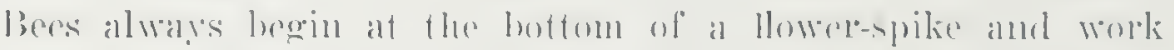

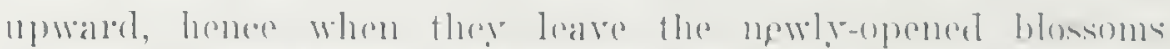
at the top they are well dosted with pollen. Flying to anothere

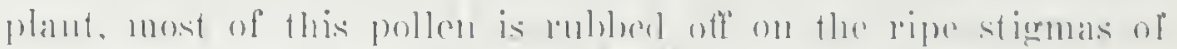

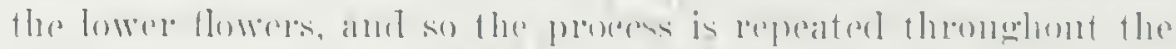

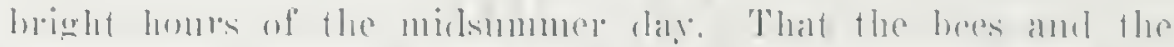

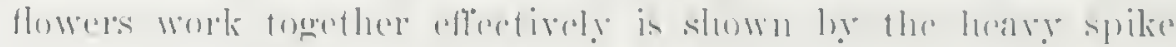

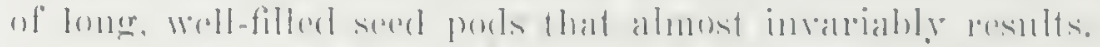

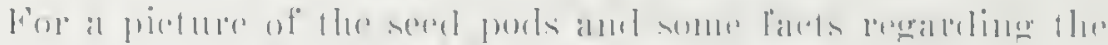

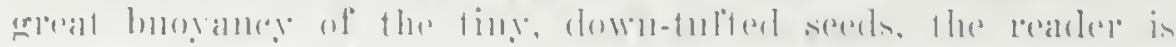
rolimed to palare 128. 


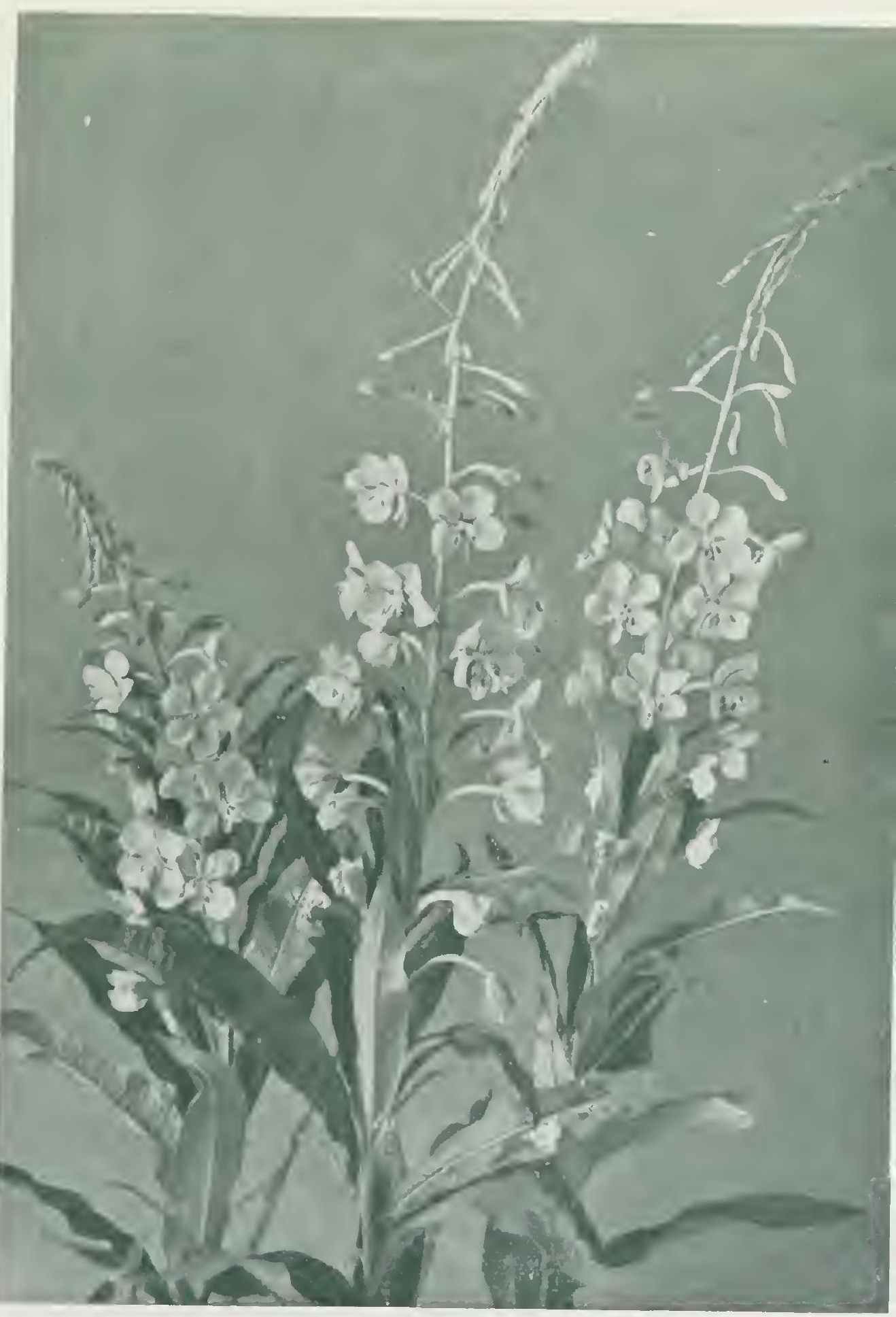

GREAT W HILOW-IIERI3; FIRE WEET 


\section{GRASS OF PARNASSLS}

\section{Parmassia palustris $L$.}

\section{Saxifrage Famiry}

For a plant with short, hroad leaves and show white flowers "Grass of Parnassus" seems a strange name. It has, however, the sanction of distinguished origin and ancient nsalge. having been applied to this very speeies by Dioserides, a learned Greek physician of the first and seeond eenturies, who has been called the founder of botany.

The entire-margined, heart-shaped leaves of the Grass of Parnassus all spring from the rootstoek, with the exeeption of a single one, which clasps the stem one-third of the way to the flower. Each stem, four to twelve inches high, terminates in a single white blossom an inch or so in diameter always facing the sky. Although of a very eommon form-open, regrnlar, and five parted - these flowers have sueh individuality of detail that onee attentively observed they are not afterwards forwoten or confused with others. The broad petals are clearly and handsomely veined with light green. In front of each stands a fanshaped group of nine to fifteen slender white filaments each topped, not by an anther. but ly a small yellow knol. Together the five groups form a kind of grille surromeding the inner parts of the fower. Since even minute cletails of structure are not witlont use and meaning in the life of a flower. it will he an interest ing problem for roaders to diseover what purposte is served by this momstual and prominent floral aceessory. The eentre of the flower is, of course, oeempied hy the ovary-the inmature seed eapsulewhich is short and rome, and bears on top three or fonl stignas. These stigmas, lowwerer, do not ripon until late in the blooming period. Surromeling the anpsule and alternate with the petals are five stamons whose method of derelopment is worth wateling. When the potals first expand each stamen is elose-folded against the eapsule. Soom one of them straightrus np, elongates its filament, and takes a plate in the eentre of the Hower direetly in the way of alighting insects. Iater. molatbly the rext day, a sereond stamen, pipening its pollen, arets in the same manmer. The other llare follow suit, the anthers of the earliele omes having meamwhile shed throp pollen and fallen off". This deliberate development quives insects ample time in which to aceomplish their mission of cross-fertilizatom, and full serel-pods nsmally lesult.

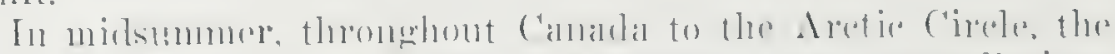

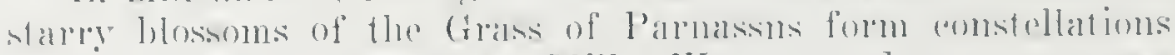

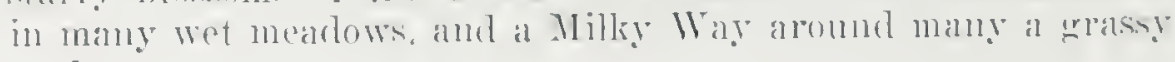
pool. 


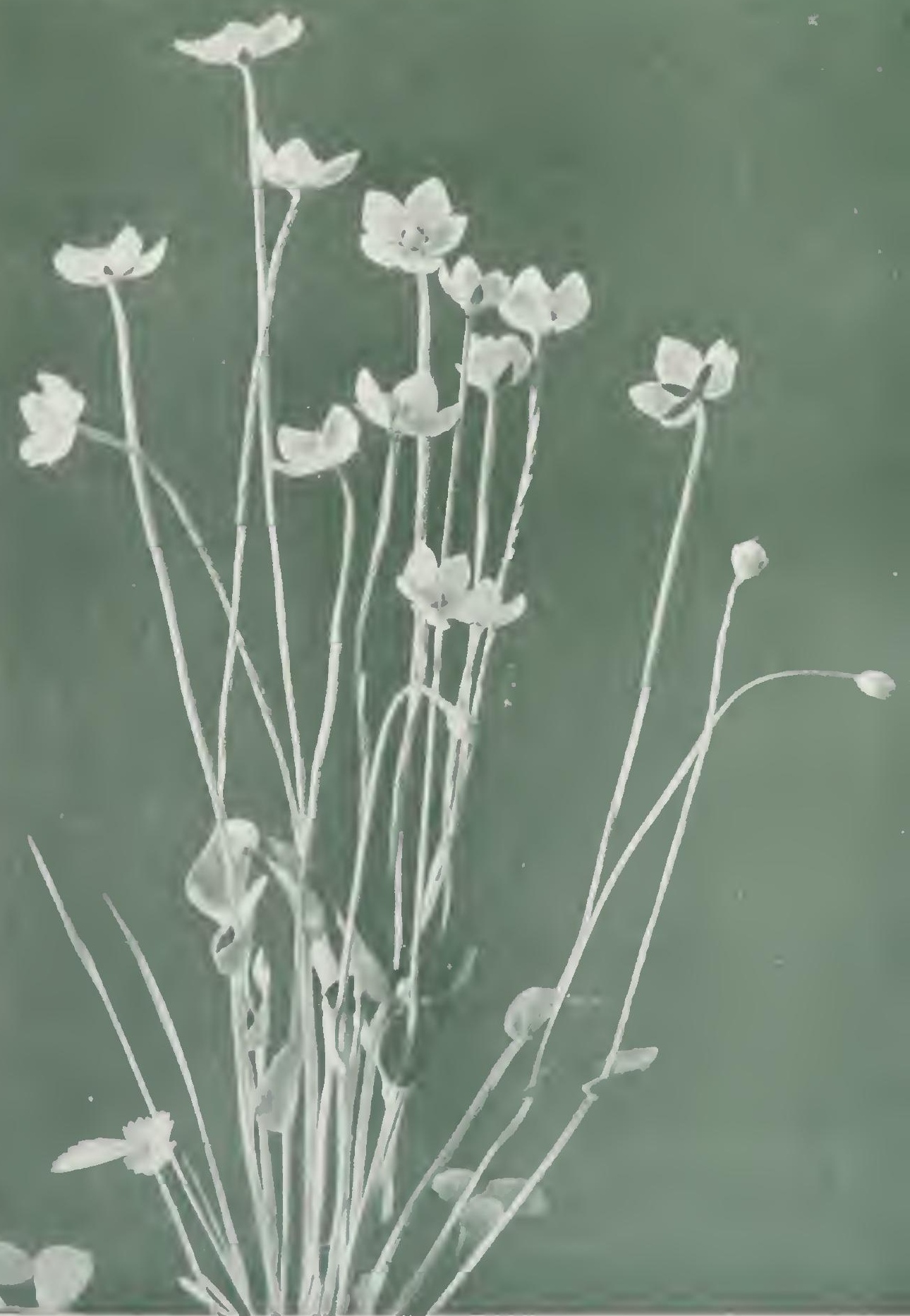

GiRASS OF l'ARYASSU 


\section{A pocynum androsucmifolium $L$.}

\section{DOGBANE FAMLY}

Although placed by botanists in a separate family, the dogrbanes are allied to the milkweeds. The same kind of milky juice promptly oozes from the slightest abrasion of their delicate skin. Both have simple leaves with entire nurgins, and both bear pods filled with down-tufted secds; but, whereas the pods of the milkweeds are fat, spindle-shaped, and upright, those of the doghanes are long, slender, and drooping. In bloom anso they differ, the umbelled, eomplex flowers of the milkweeds being replaced in the doglanes by open elusters of simple hell-shaped flowers.

The Spreading Dogbane, a common plant throughout Canata, grows on wooded banks, among thickets, in ficlds, and along roadsides. Studied in these different situations, it exemplifies very nicely the influence of illumination on plant form and growth. In woodlands the plant is tall, and the leaves on each branch are arranged in one plane in order to take full adrantage of the overhead light; the flower chusters terminating the branches are comparatively small, and the whole effect is that of a richlyleaved plant sparingly adorned with pretty pink blossonss. In full sunlight the plant is fower and nore spreading, the leatres ane smaller, relatively fewer in number, and nore or less fwisted out of the horizontal plane. The flowers on the other hanel are much nowe abundant, and often the large open elusters on the more numerous branches unite to form a floral hemisphere, or sometimes almost a sphere within which the leaves secm of quite secomblary importance.

As might be expected, the plants growing in the open bear the speater number of seed pocks, for insects lore the sunshine, and, like the milkwereks, the spreading Doghane is elependent upon therie good offices for the fortilization of its flowers. It has, however, a terrible way of punishinge ecrtain small flies who apparenty ate mable to be of serviere in this nuater and

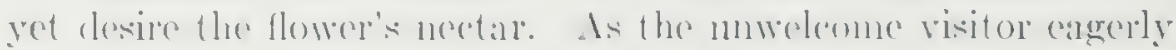
reaches for the honey, it frepenenty hatppens that his tongue is catught in a moteh in the contre of the flower, and, mathle to frees himself, the mulinply areatume slowly dies of stamation. In the

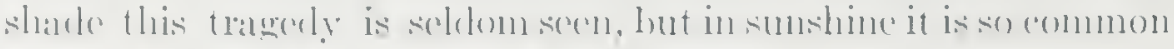
that the plant is sometines eallerl Fly-trap. 


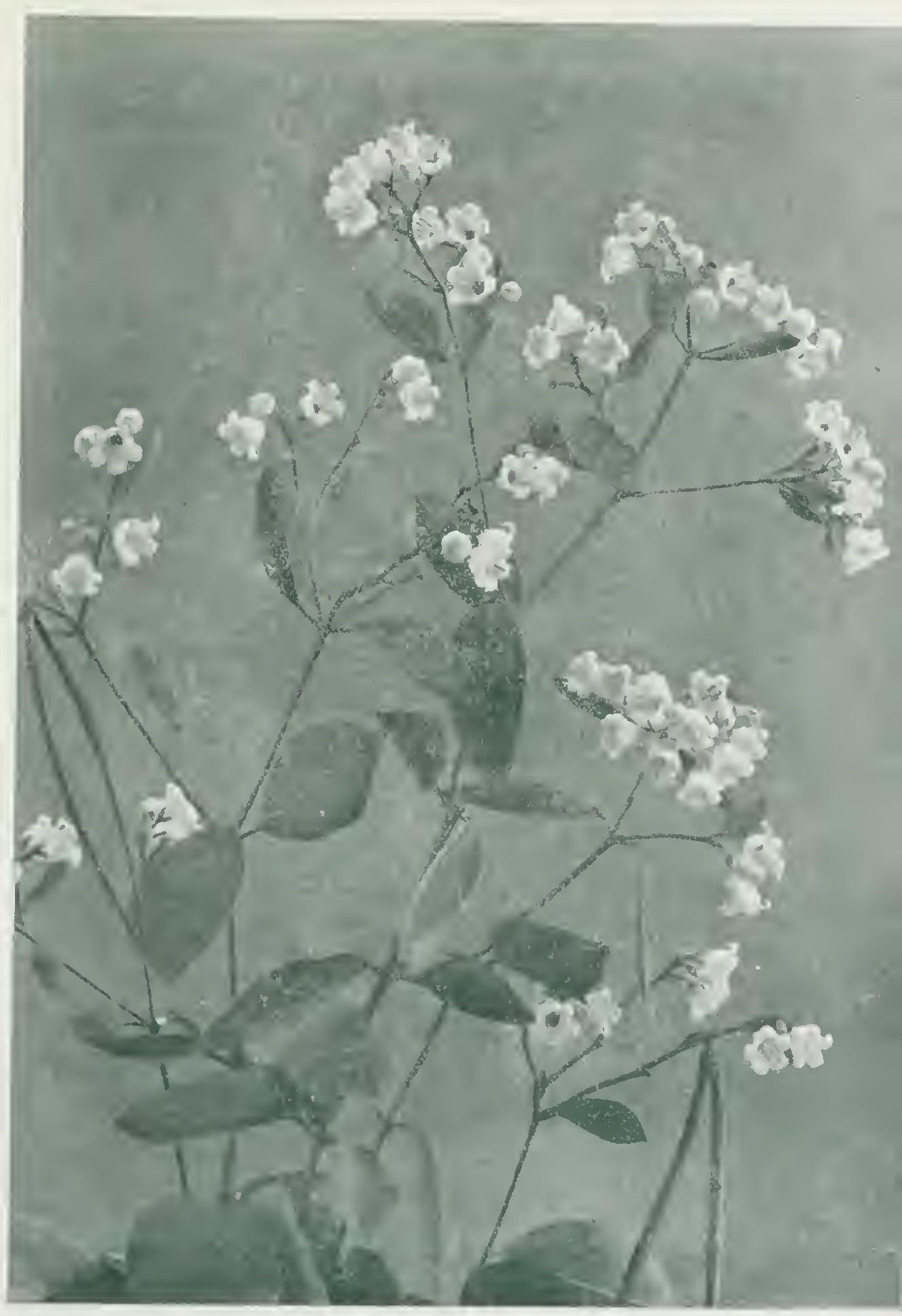

SPREAMING DOGIBANE; Fly-TRAP 


\section{GIANT HYSSOP \\ Ayastache Focniculum (Pursh) Kiunlzo}

MINT HAMLI

In midsummer the breath of the prairie is fraterant with the spicy odors of the mints. In midwinter, if onc shalie mp the laty in the farmer's nnow, the air at once becomes mololent with the same perfumes which recall to menory the warmth and roblor of the sunlit plains.

C'ertain members of the family are low-set plants with small flowers elustered in the axils of the leaves: others, like the Mild Berganot rescribed on a previous page, are taller with showy terminal flower-heads; still others are coarse and weedy.

This Giant Hyssop, a tall and handsome mint, may frepuently be seen on the plains, alone fence rows, and among lumshes from Manitoba to Alberta. Its smooth, sliaply angled stoms wrow from two to four feet high. Its anise-seented lates are of marlied beauty, being firm in texture, triangular-ovate in ontline, shluply and evenly toothed, dark green and strongly verined alrove. and a clean white beneath. 'The flowers, produced overe a longer soason, are borne in teminal sprikes two to five inches in longth. Frequently these spikes ane compact througlont, hut the latrerer

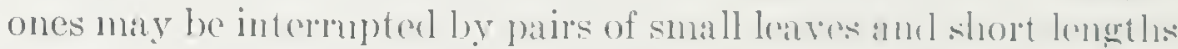
of stem. There bright blue rorollas, about two-fiftles of an inch long, projecet almost at right angles to the stem. 'The calyeces are also tinted blure, and after the comollats wither anel fall ofl this blue slate derpens, leaving the tall, leaty wands still consplemens and decorative thromets the rest of the simmmer.

lt is interesting to notice that, whereas, in al simple flowerspike the blossoms open in a regulare, cisily rorognizorl orelere,

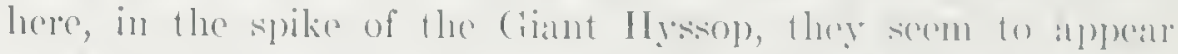

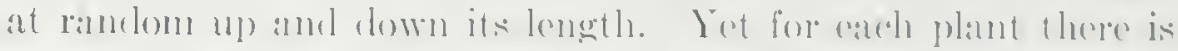

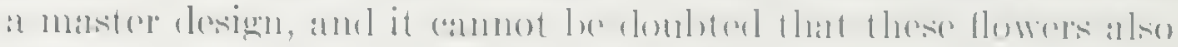

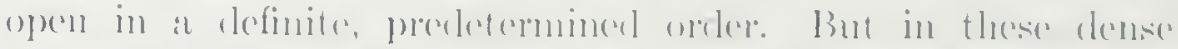

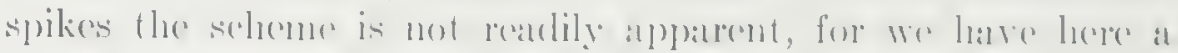

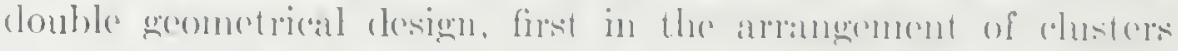
on the strul, and seronel in the arrangement of thewres in the ('lustrer. 


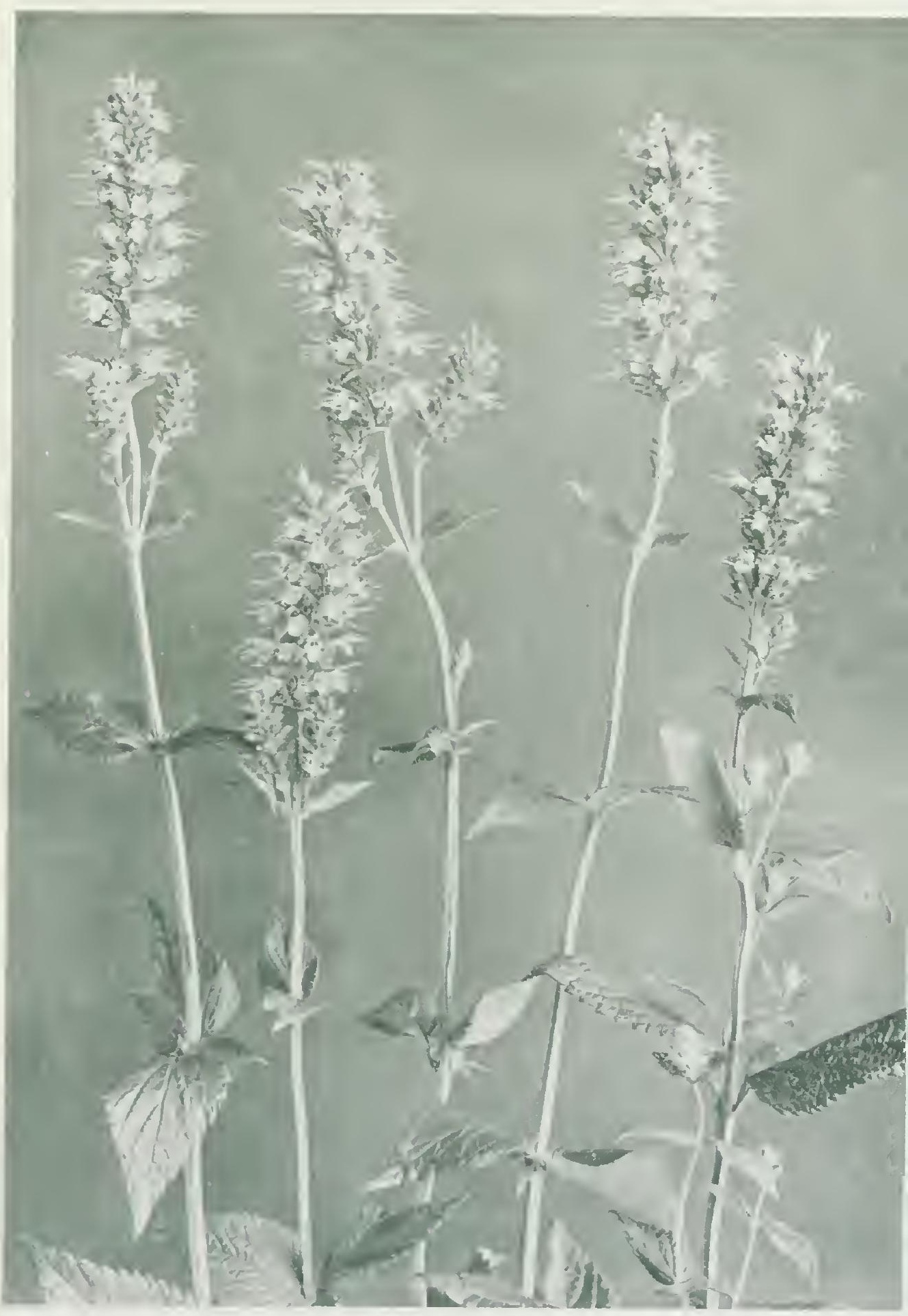

GinT HYssof 


\title{
WILD MORNING GLORY; HEDGE BINDWEED
}

\section{Convolvulus sepium $L$.}

\author{
Morning Glory Familo
}

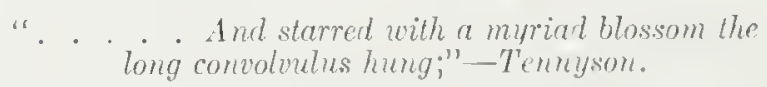

Draping banks, bushes, and fences with handsome foliage and beautiful trumpet-shaped flowers, the Wikl Morning (ilory twines its graceful way from Newfoundland to British Columbia. Its trumpets are sometimes pink with white stripes, but in Western Canada they seem to be usually white, and since we have here the unusual phenomenon of both pollen and pistil being white, the flower is arrayed in bridal purity. In the throat of the flower are fine tubes in a circle (they may be readily seen in the picture opposite), each with a honey gland. Occasionally a big sphynx, or humming bird moth may be seen hovering over these wells of nectar, but in Western Canakla certain species of bees are the usual insect visitors.

The Morning Cilory elimbs by twining its stens around any support within reach. When, in the fipring, from the peremial root a new shoot starts growth, its tip begins to rerolve. Describing, as it lengthens, ever-widening circles, it secks something on which to ascend. If fortunate in touching anything, it at once begins to entwine the support and secms by such contact to be stimulated to greater growth. If nothing be fouml, the shoot at length becomes so heavy that it falls prostrate, but the growing tip, like Antaeus touching the ground, finds new st rength from the contact to again raise itsolf and swing in circles from this advanced point. If several shoots chance to come together they entwine each other, forming a living cable. Such cables may often be seen writhing up from the ground as if in an agony of endearor to reach some support. Being stiffer than as single strand, they rise higher and may sometimes attain to an overhead branch that woukt be beyond the reach of a single shoot. The claim has heen made that elimbing plants an sense in some way the proxinity of a suitable support. Wonkerful stories in support of such a clain have been tokl. But, on the whoke, falets seem to discredit such a theory. The reater may asily try some simple experiments which might help to decide this interesting point. 


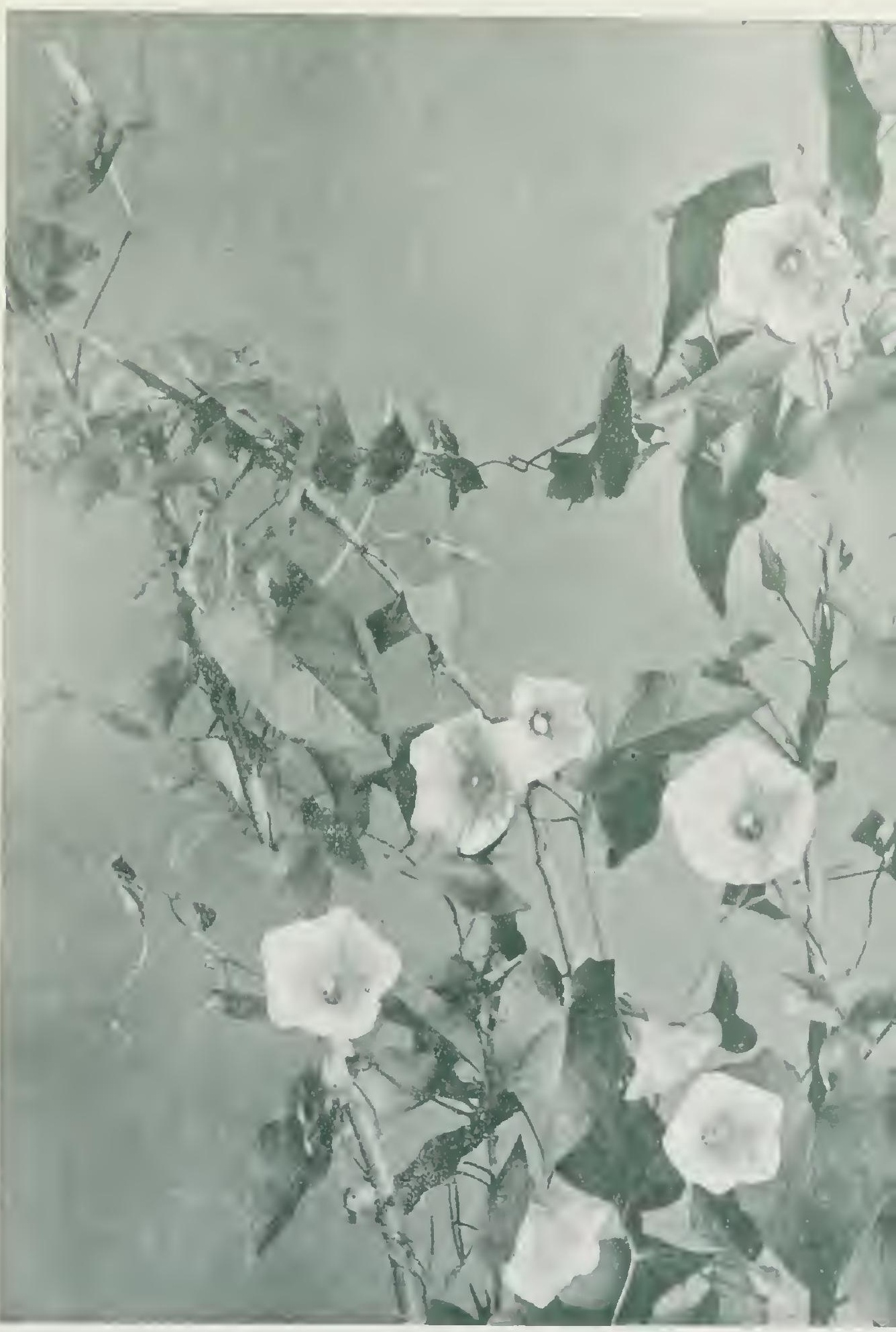

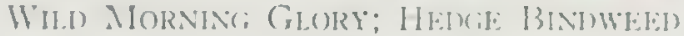




\title{
BLAZING STAR; BUTTON SNAKEROOT
}

\author{
Liatris scariosa Hilld. \\ Thinteg Fandu
}

Common names of plants are oft-times eurious and sometimes inappropriate, but whoever called this one Blazing stal had a pretty fancy. The plant grows on dry plains and hills anong short grasses above which the flowers shine brilliantly. (On nearer view, the overlapping luacts of the involuere-the seales surrounding the flower-head-are seen to be rlark red in color. As the florets open, long style-loranches of a vivirl rose-purple are thrust out, as if from the chull smoklering glow of the burl had erupted darting tongues of flame.

Is to it: other name, Button suakeroot. the button is the globular eom, or rootstock, an inch or so in cliameter. at tho base of the stem, and it is reputed to be a remedy for snake hites.

The plants vary in leright from six to cighteen inches, depending upon the fertility of the soil and the amount of moist ure it eontains. They ane in bloom about the first of August. The flowers are interesting and unusual for this reason:-In most flowers the styte is rather inconspienous, its function being to connect the stigna and orary, and fo holel the stigma in the proper position

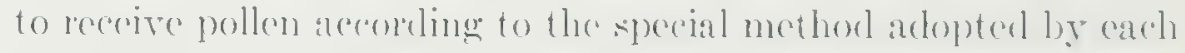
plant. But in the case of the Blazing star, although the stylehranches ale stigmiatose only at the base, there is a remarkahle

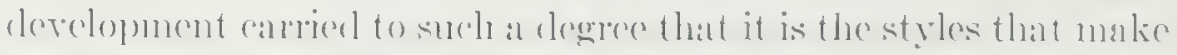

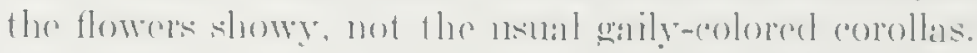




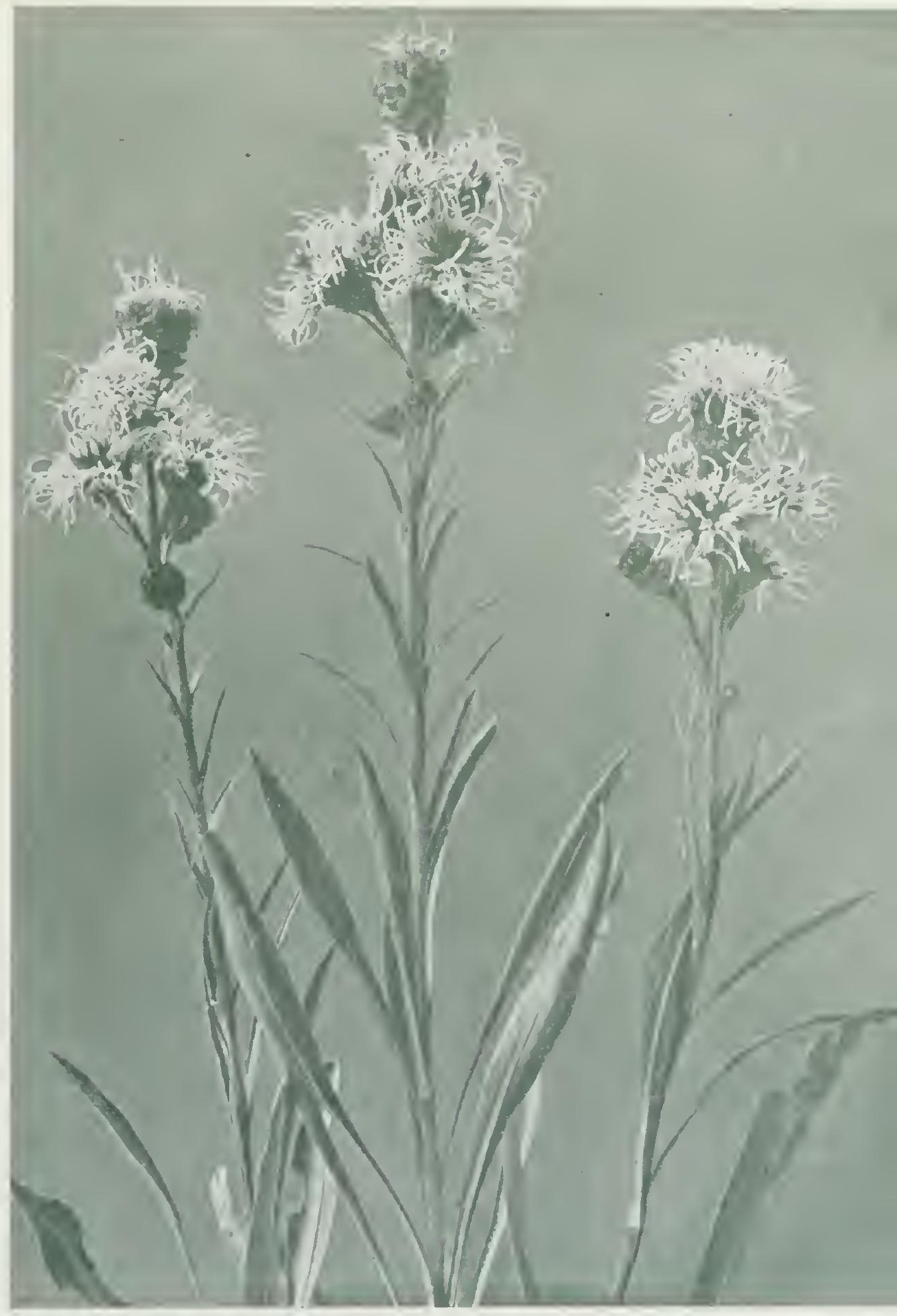

BLAZING, STAR; BUTTON SNAKEROOT 


\section{PAINTED CUP; INDIAN PAINT BRUSH \\ Castilleja miniata Dougl.}

Figwort Family

That the finwort family contains many floral oddities is evilenced by the common names of some of its members, such as snapdragon, tuntle-head, monkey-flower, owl's clover, elephant's head and so on. Nor are these names so willly fanciful, since the resemblances are sometimes very real. In the elephants head for instanec, each tiny flower on the long, slender spike imitates the broad spreading ears and the upturned trunk of the elephant in a remarkable manner.

The Painted Cup, a familiar plant from Manitola to the lockies, is curious in a different way. The flowers are borne in clense leafy spikes at the top of a leafy stem, but, being greenishyellow in color, they are scarcely noticeable among the longer and more brilliantly colored bracts, which look as if they hat been dipped in a pot of scarlet paint. Its other common name-Inchan Paint Brush-is therefore more approprite than Painted (up). Still, the color of the bracts varies greatly, not only in the several species found in Western Canacka, but also amonge different indivicluals of the same species, langing from searlet and brick-1ect to rose, pink, and even to white. Individually, the plants are rather coarse but in the mass their effect is beautiful, and many a hiblsile and prairie secms aflame with them.

Not the least, interesting fact in the life of the paint brush is its deviation from what one might call the standarts of common honesty in plant life. For frecuently this plant attaches itself to the roots of ot her plants and steats from them their life juices. In short, it serms to be lyy instinct, if not always by opportunity, a parisite. Still its molal decleusion is not complete. For in the "ase of these plants which are wholly parasitice in nature their low chameter is usually reveated by the alsenere of green eolor in their leaves. But where, as with the paint brush, the theft is incidental, as it were, where the plant can, and to a cortain cextent rloes, live ly its own exertions there is usully little outwarl sign of this brand of degeneracy. 


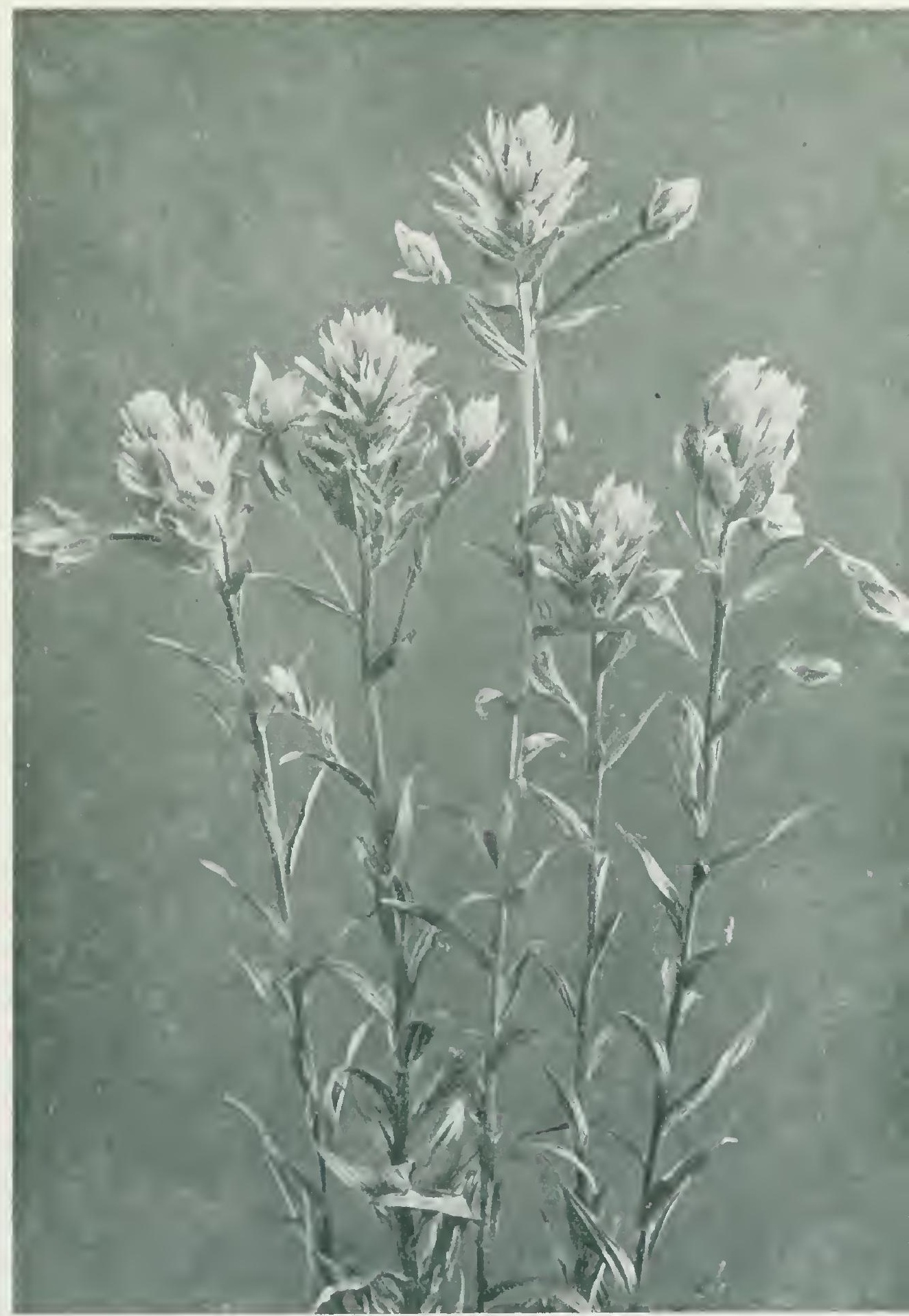

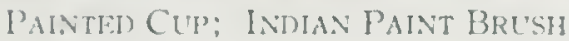




\section{A WESTERN RIVER SCENE}

"But lhere is one llimg a large river aloes for one thal is beyoul the scope of the companionable strenm, it idealizes the lamdsenpe,

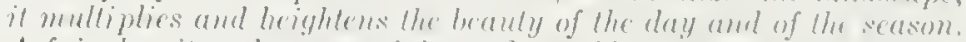
I fair day it malies more fair, and a wild and lempestuones day it

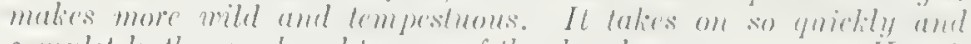

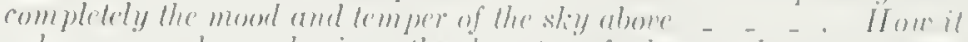

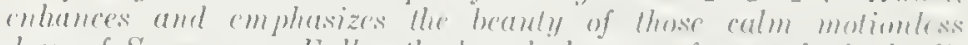
dengs of Summer or Fall, -lle broat glassys surface perfectly duplicaling the opposite shore, sometimes so smoold that lhe finet fleseling maller here and there loolix lilie dust npon " mirror; -"

- John Binromelis.

Not always is the river so placid ats in om pioture. Whem smmmer heat melts the snow on the mountains, and smmmer rains along its great length swell the flowh, the watcre rises mapitly and swepps along in swelling strength chafing at its steepe chay hanks and earrying away soil and plants that are not firmly

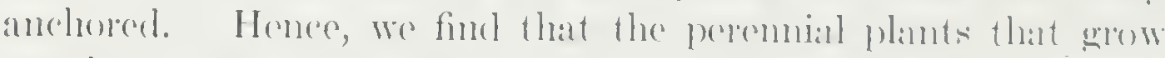
on these stecp river banks are either grasises with numerons intertwining rootstoeks fimly hinding together the soil, or ohere plants that have deep and strong roots, like Hooker's mugwort, shown in the foreground of our picture, Mackenzice serlyarmm, the deflexed oxytrope, and other herlse of like lablit. Sometimes:

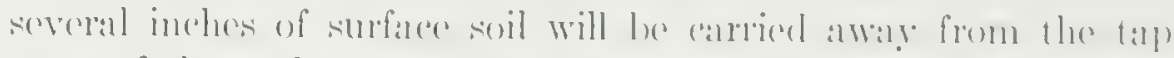
roots of these plants and the reots with their fufterl stoms lamer down, dirty and forlom. But abatement of the floosl hrings

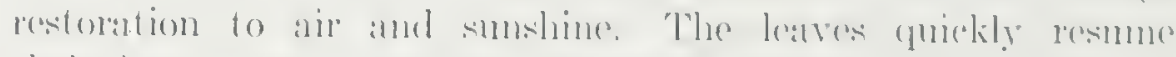

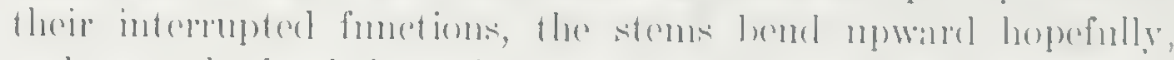

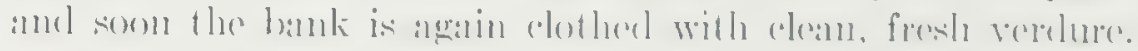




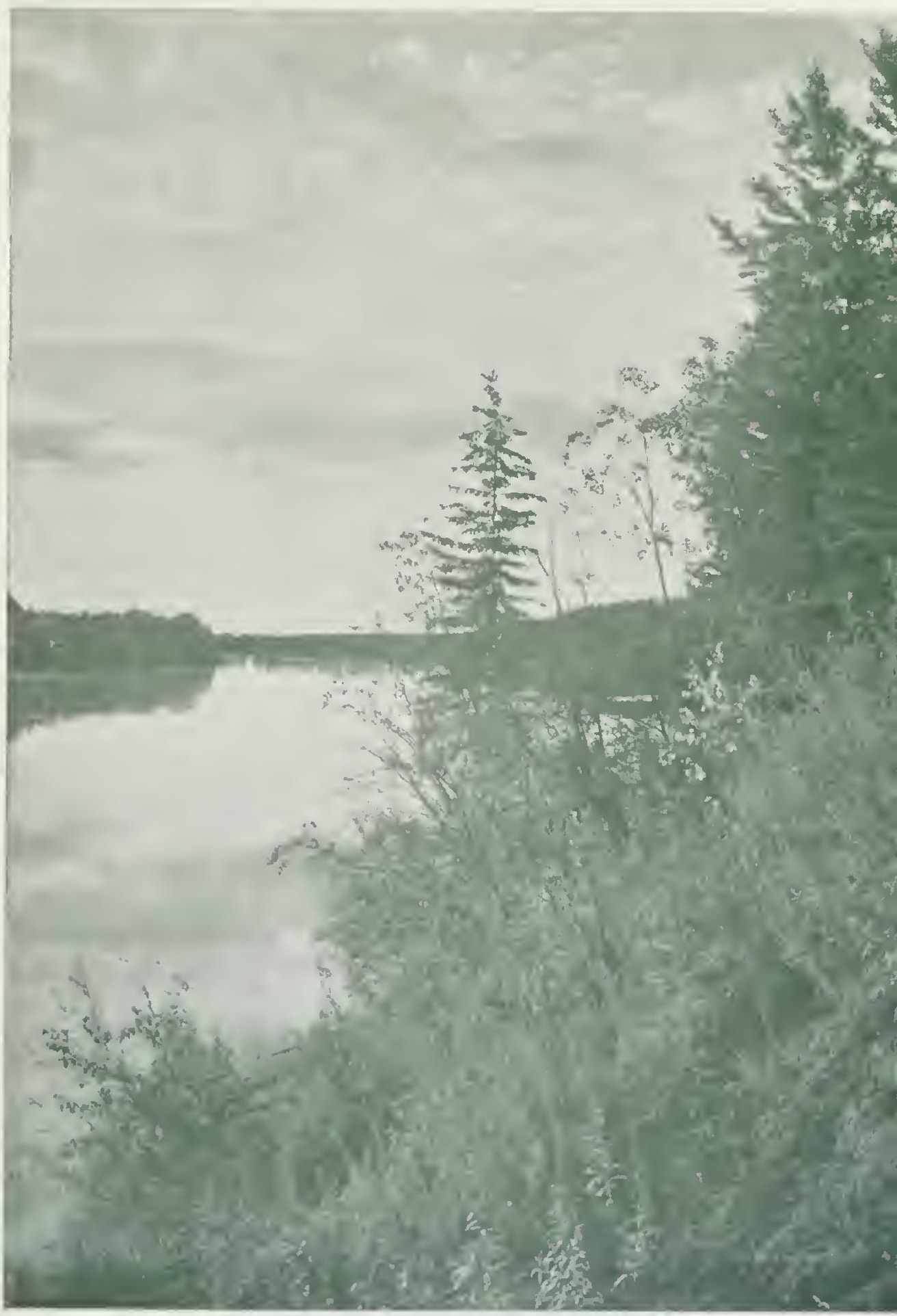

A W ESTERN RWER SCRNE 


\section{GIANT SUNFLOWER}

\section{IIelianthus giganteus $L$.}

THistle FAMIL

The Giant sunflower is so called because of its tall stems which sometimes grow tou feet high, although half that height or less is commonel. As compared with the thick stems, hroad leaves, and massive heads of the eultivated Russian smblower, it is not at all gigantie, for its stem is usually much branched and, execpt at the base, wather slender, its leaves narrow and taperpointed, and its flower-heads only two or two-and-athalf inches across. Still it is a hig, vigorous plant and with such al caplaceity for spreading and massing that it may often herene a troublesome weed in low gromel. From the Lake of the Woods to the Rockies, the Criant Sunflower is abundant and fumbles in many a miclsammere landseape great expanses of radiant color.

If a stem of this hig hert be dug up in Autumn it will bring with it a great cluster of roots. Some are ordinary foreding and anchoring roots, others ale so thickened as to look like small sweet potatoss. From among these, spmeading out in all dinections, are stout erecping rootstocks. In these spindle-shaped tubers is stored enenentrated huilding material upon which the rmmers draw in early spring, so getting a gool start in thoir work of extending the sunflower eolony". 


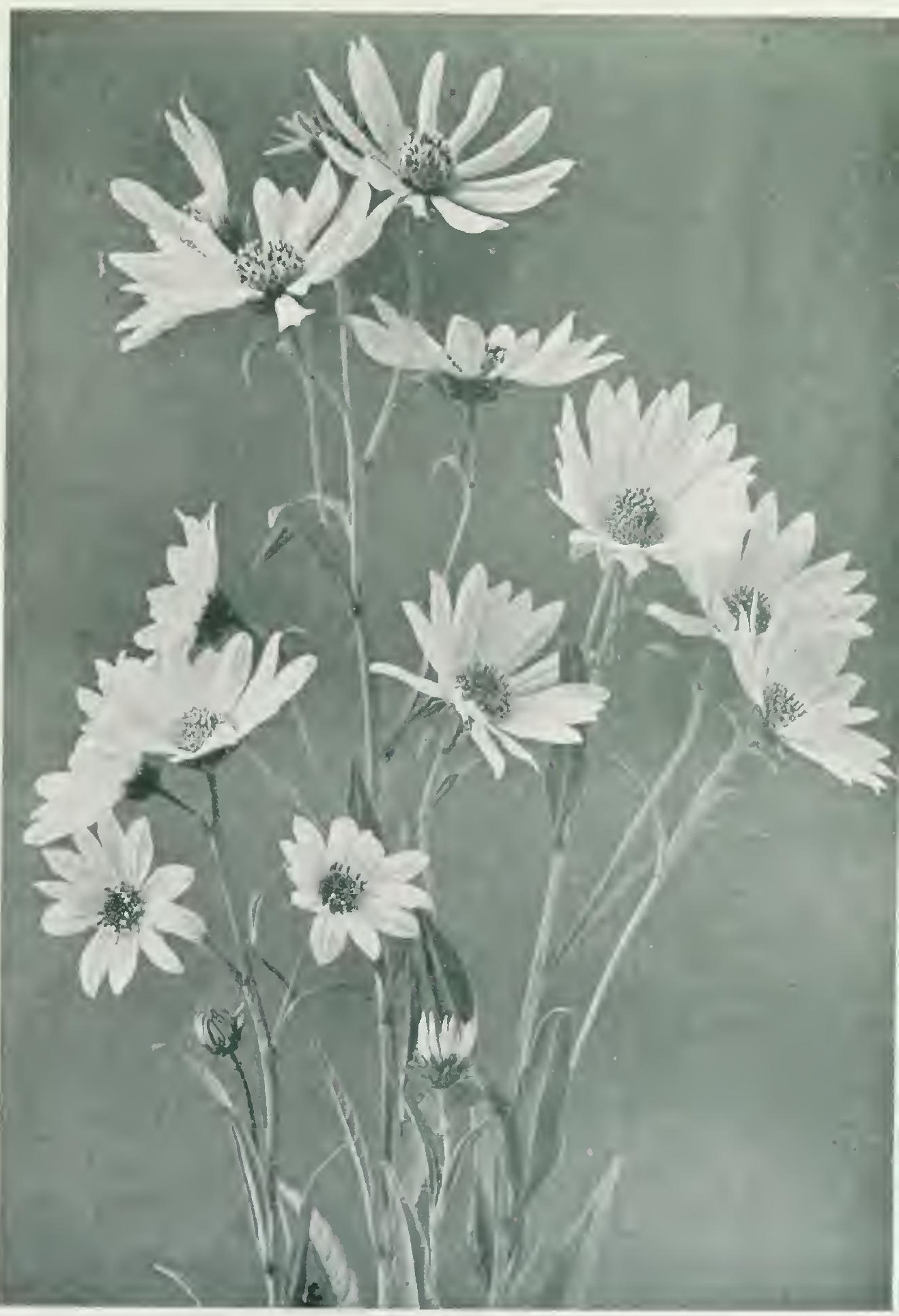

Ginnt Sunflower 


\section{BROAD-LEAVED ARROW-HEAD}

Sagittaria latifolia Willd.

WATER-ILANTAIX FAMHLY

A handsome plant is the Arrow-head with distinctive and decorative leaves and flowers. Growing in shallow water or mul, atong the margins of ponds and streams, it occurs commonly and often abundantly throughout most of the North Anericin continent. Since aquatic plants are subject to suchlen changes in their surrounding contitions-floods may increase the eurent of the streams and raise the water in the ponds, or dhought mity dry up both - it is not strange to find that this plant exhibits great variation in size anel form. Its height may be six inches or two feet. Its leaves may be hoal or narow, but, unless submerged during growth, they retain their arrow-head shape. The plants are occasionally diocedous hut usually monocedous, that is, hearing both male and fentale flowers on the same plant but separately. As may be seen by referring to the picture opposite, both kinds grow in cheters of three around the common flower-stalk. Both kinds also have three glistening white petals more delicate than the most ganzy fabric ever spun hy man. I3ut in the ecntre of the male flower is a beantiful cluster of eqotedenstamens, white in the fomale flower is a dull gereen, rounded mass of pistils.

The superior beanty of the mate over the female blossom, although not fully apparent in one picture, is quite pronouncod, ancl follows a general rule anonge plants. Mamy other examples of this might be mentioned for instance, the long drooping male tassets of the hireh amd alder as eompared with theip smalt inconsplenous femble catkins, or the golden dress of the male witlow as compared with the quieter silvere of the fomate. Again, in the rase of the cultivated squmsh or pmuplin, both sexes have

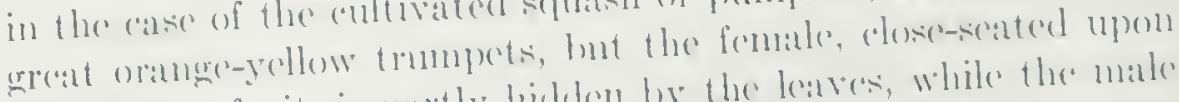
the embrye fruit, is partly hichlon hy the keaves, while the male rises up on a long stalk to hetter display his splemetor. Iet these deeorative distinctions of male and female dress and form are mot motived hy anything arerespombling to human vanity; rather they sprine from vital necessities in the life, not of the inclividuat, but of the spereies. 


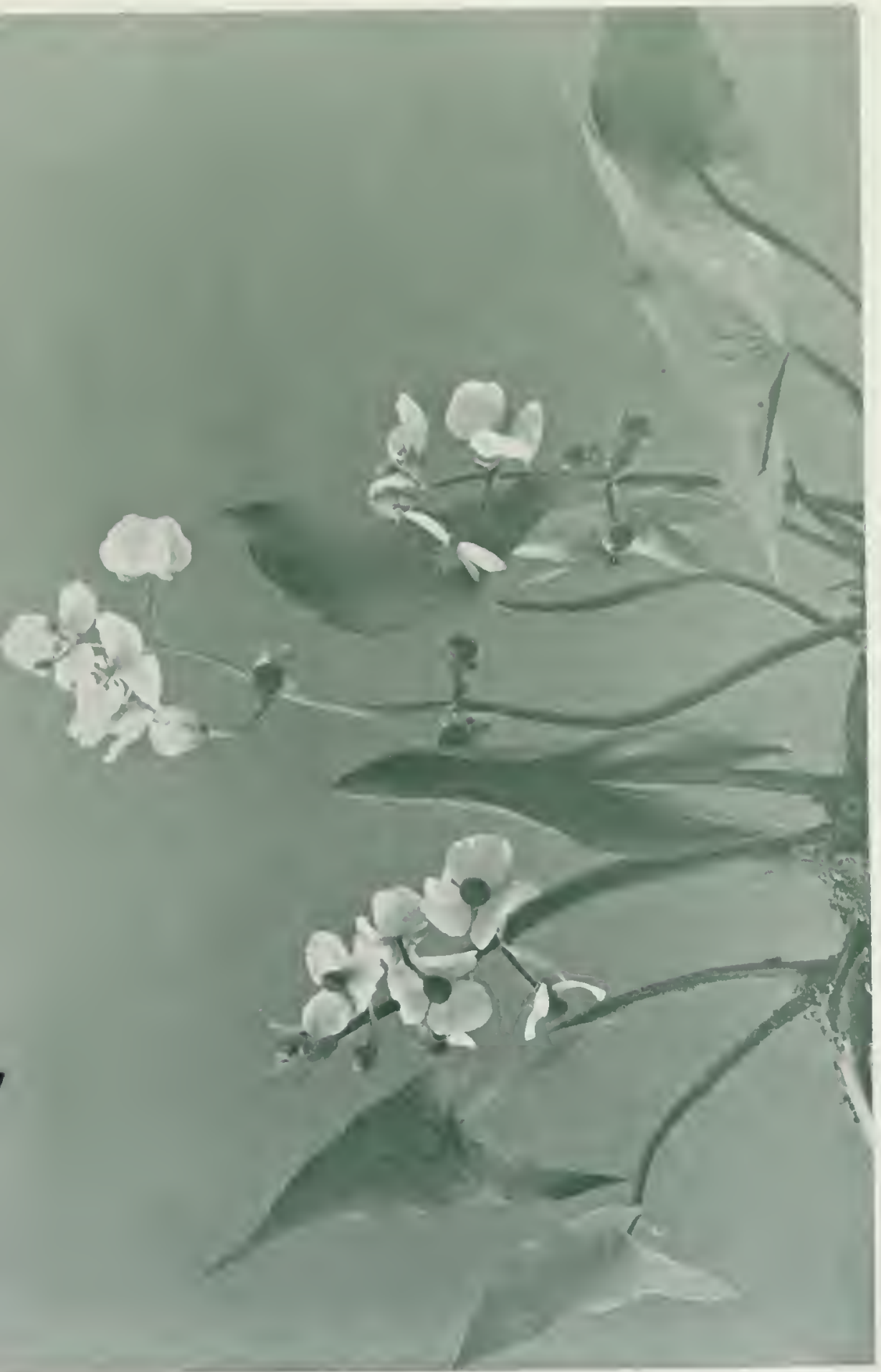

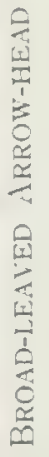




\section{MARSH FELWORT}

Pleurogyne fontana A. Nels.

Gevtian Hamey

This plant is probsably an unfamiliar one to miny of our readers. It is said by the late Mr. J. M. Mateoun to be characteristic of alkali flats in the sonthern part of the prairie country, and Ryelberg's Flora gives its habitat as momutain bogis. The plants pietured on the opposite page grew hundreds of miles from the international boundiry and far from the mountains, and it probably oceurs on brackish shores anel in salt marshes over a wide range.

One reason why it is little known is its laibit of opening its flowers in bright sunshine only, and then for but a short time. Another is that its usual rather desolate smroundinges do not promise the flower lover much in the way of floral beanty, and he is likely to turn to more fertile fields. Finally, it is a capricions annual and may appear in a neighborhood one season and then not to be seen again for sereral suceeceling years. In this latter elusive quality it resembles its beautiful relation the fringed gentian whose flowers of heavenly blue have cuptivated alike the poet and the artist.

Individual plants of the Matroln fielwort, cren when growing together, differ "uriously in size. Some are there or four inches high bearing but one or two blossoms, each slenter stem bending to the lightest breeze. Othere grow to a height of fifteren inclues and are stifly erect with a dozen or more close-set flowers. The white corollit is so decply eleft into four or five lobes, that eacte seems to be a separate petal. At first sight, also, the flower seems to have nejtleer style nor stignils. The style is indeed lacking, but elesere examination will resel the latter ats stigmatose lines on the sides of the ovary- quite an umisual artangement.

The flowers open in late summer and it is always a plestsant surprise to find surch pure and dwheate beanty anicl the usual coarse vegetation of its (nuviromment. 


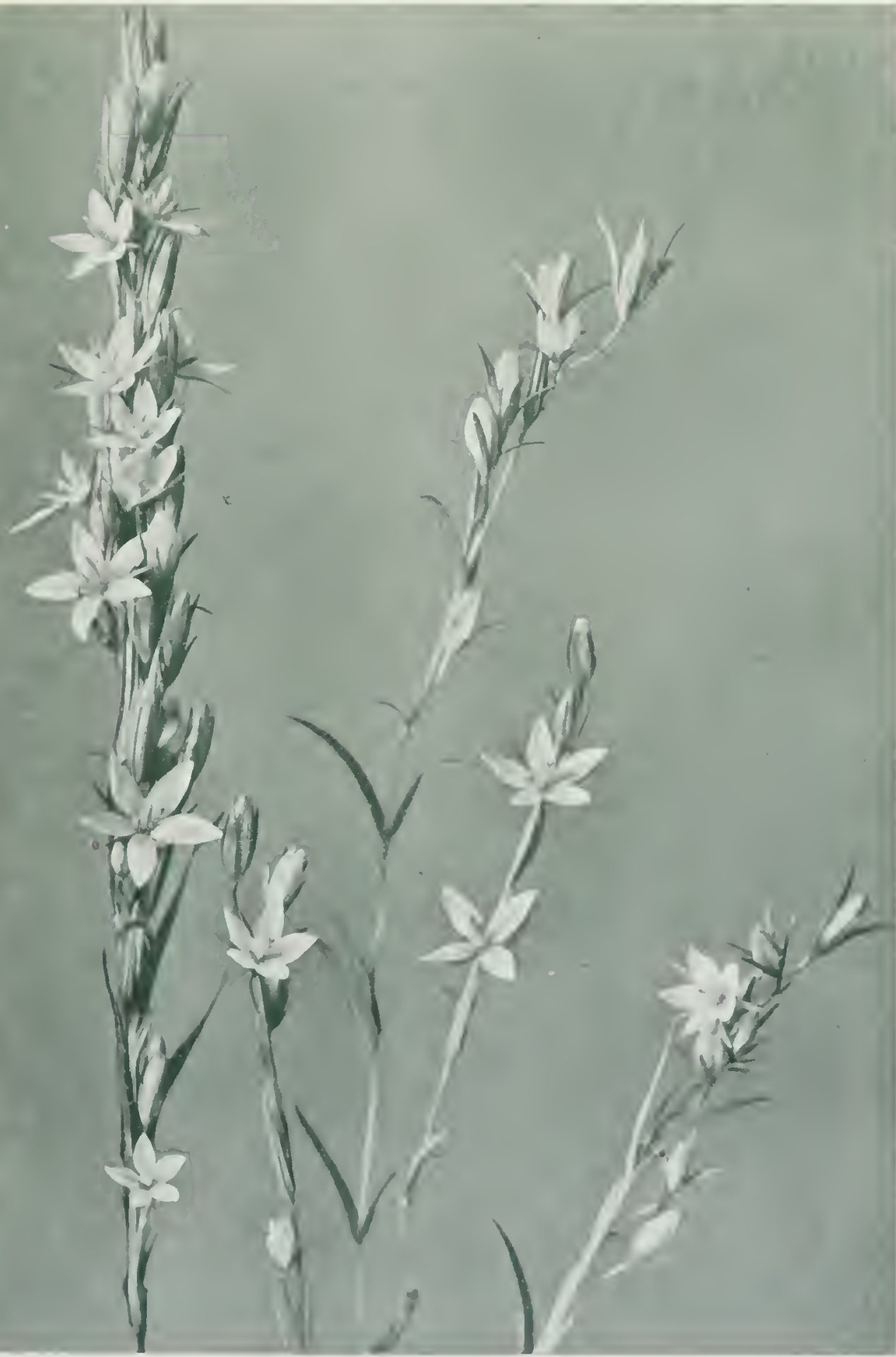

Marsh Felwort 


\title{
LESSER PASTURE SAGE BRUSH; WORMWOOD SAGE
}

\author{
Artemisia frigida Willd.
}

'THSTLE FaMIIY

In Westem Canada grow many species of Artemisin, known variously as wormwooks, sage brushes, or mugworts. Mlost of them are dry gromel plants, a few are found in moist valleys, and one at least (A. biennis) has beconce in many places a common and unsightly weel. ('rotain kinds, rspecially the European wormwood (A. Absinthium) grown in many garlens and escaped from them to the roadside, are so widely used as domestic medicine that "wormwood tea is an olorous menory with every person who was reared in the country." **

Those species of Artemisia commonly callerl sage brushes are characteristic of arid regions, where over large tracts they sometimes constitute almost the entire regetation. He luve all heard of, even if wo have not seen, the sige brush desert whose gray monotony impresses travellers as they cross the continemt by southern railway lines. Fuch universal grayness of tone is due to the fact that stems, laves, and flower-heads of these plants are all densely coated with white hair or wool. The protection thus afforded is two-fold: first, transpiration is ereatly dininished; and, second, the chlorophyll-the green coloring mattel of plants in the tissue beneath the hairs is shated as by an awning form the destructive action of too intensce sumshine.

The Lesser Pasture Sage Brush pictured on the opposite page is one of the smaller of these desert siges. It has, however, at range extenting far beyond the desert, heing found northwarl as far as Hudson's Bay and Maskit. Over monch of this great expanse it orems sparingly in small colonies on particularly dry banks or hillsides, but in the arid part of the Camadian plains it sometimes covers the gromul over considerable areas.

Considered, not as a humber or a thomsand ace canpet, but indivichally in detail, it is a pretty plant with soft masses of funcly-eut, silvery foliage above which in late summer rise silvery plumes cight to twonty inches high. Mlong the slender branches of these stems are strung ronnd and nodding flower-hoads, pearly gray on the ontsick, hut som opening to enit the tiny yellow florets.

- Liberty Hyde Bailuy. 


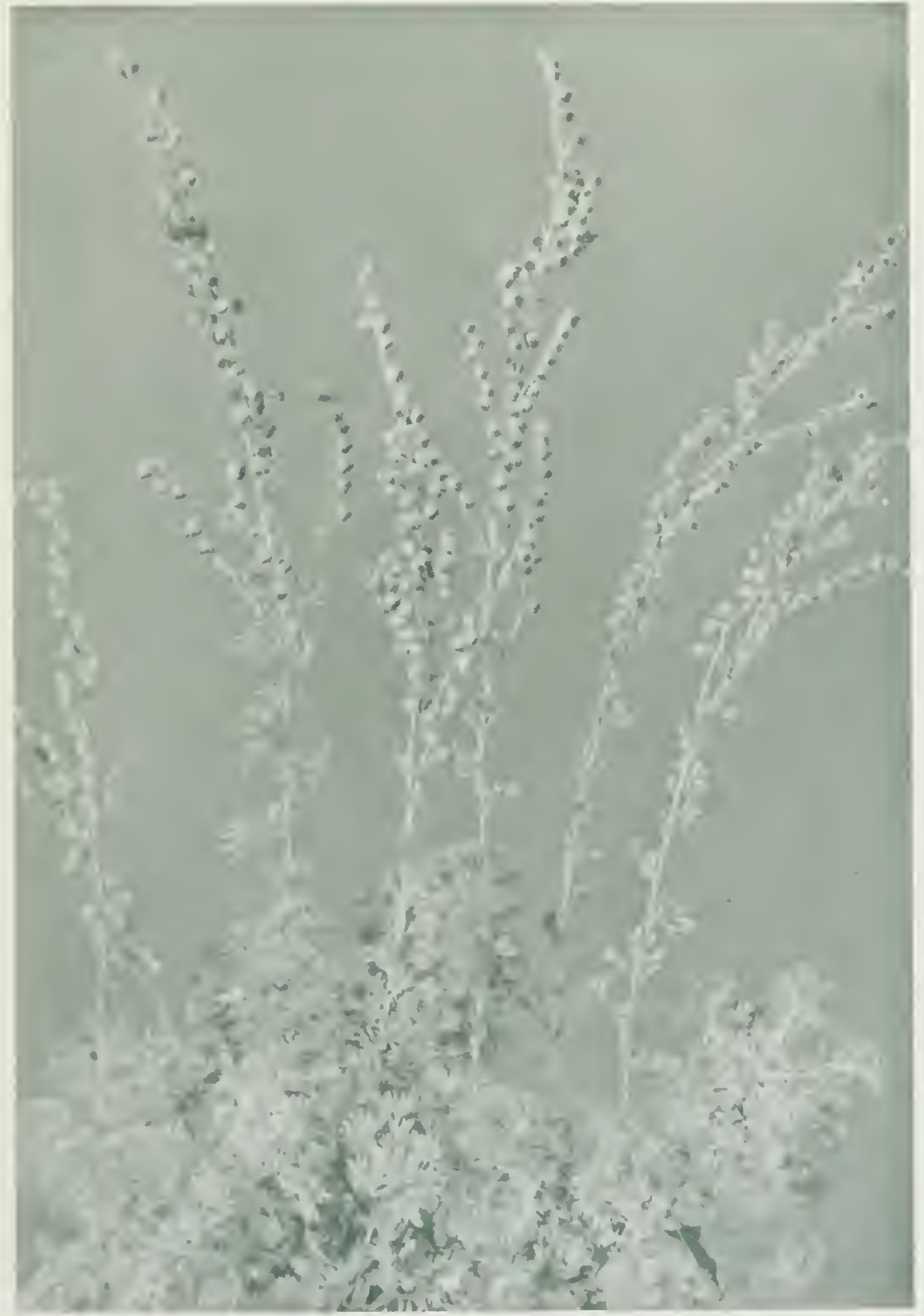

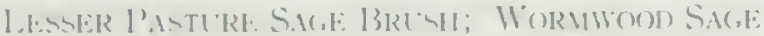




\section{WHITE PRARIEASTER}

Aster commutatise T. and (:

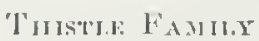

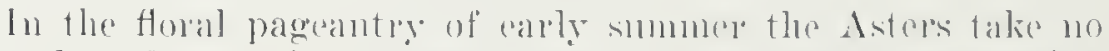

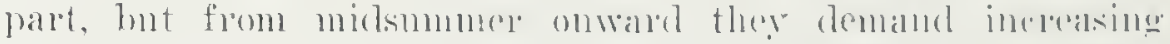
notice until in the elimax of splendore with which the season closes they oecupy the premier places Othere hamelsome flowers in great number and valdery join in the display, hut many of them furnish only hore and there ontstanding points of eolore, valuable additions to the erenelal effect, hut still merely inci-

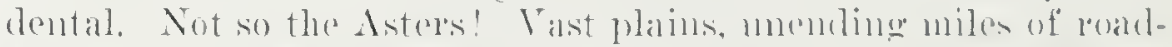

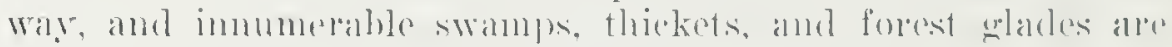

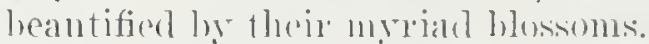

Asters respond kindly to lomman ande. and in England these

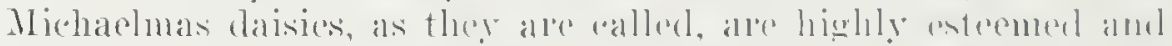
genelably cultivated. In ('andata little attention of this kind

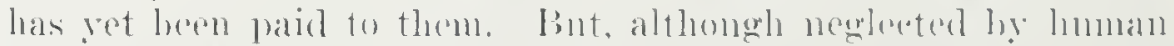

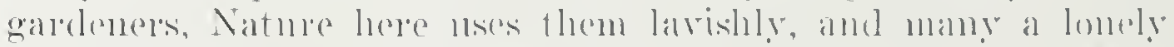

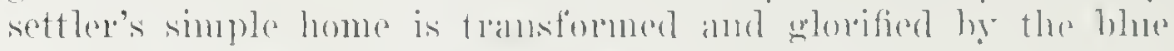
and white of anders and the renlow of goldemends.

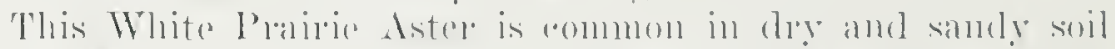

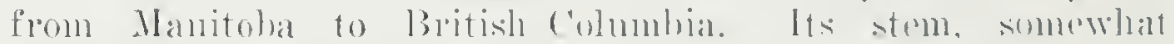

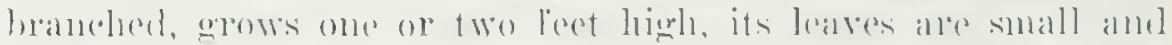
marrow, botle stem and leaves ane hairy. but one motices little

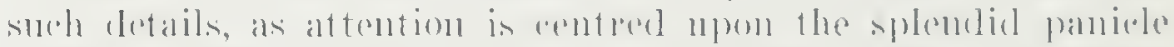
of white flowers, a paltienlanty fine sporeinese of which is show ont the opposite palge.

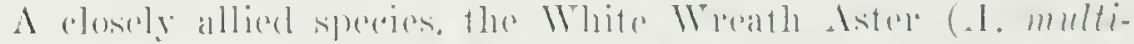

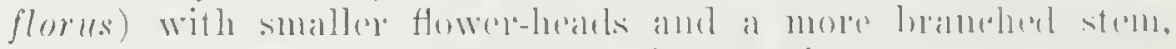

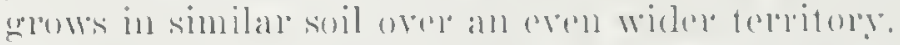

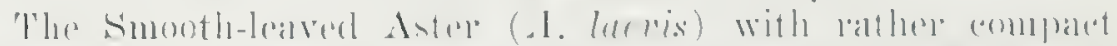

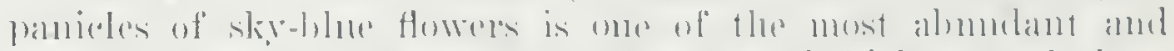

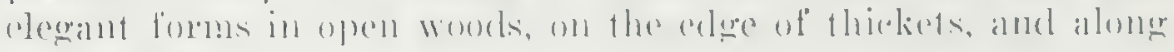
forlue lonts.

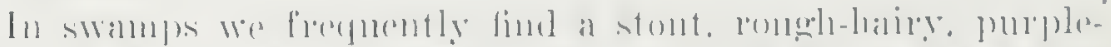

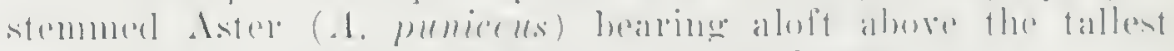

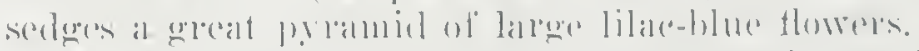

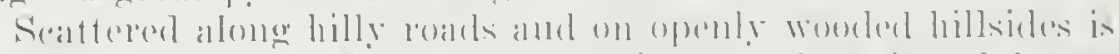

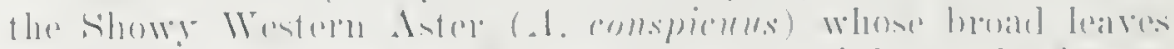

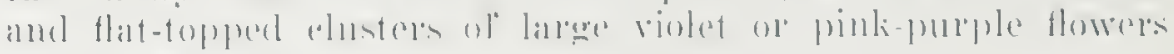
quite justily its name.

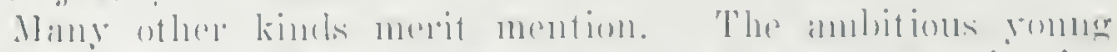

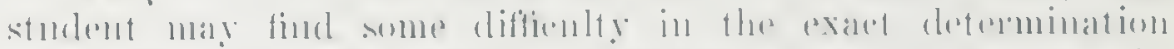

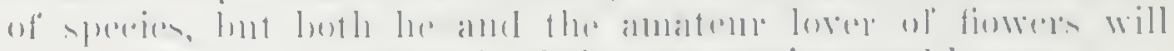

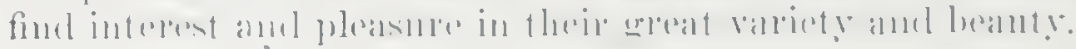




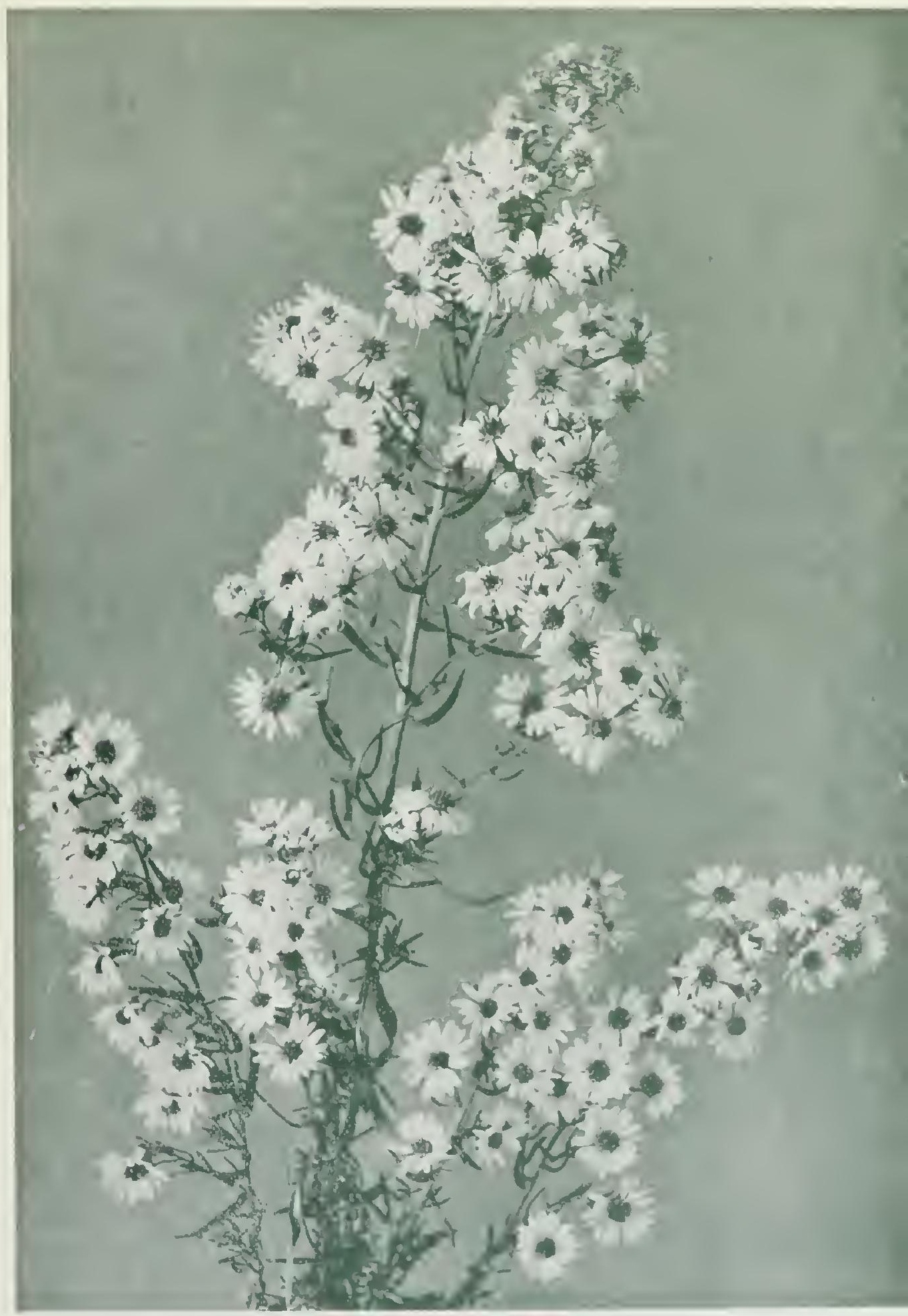

IIHTE T'R.HRIE ISTIR 


\section{DRUMMOND'S DRYAS FRUITING ON A GRAVEL-BAR}

\section{Dryas Drummondii Richards}

ROSE I'AMIIYY

Having now considered mauy flowers, it sems fitting that, before bringing this series to a close, we slould glance at a few of the seeds, or fruits as a botanist ealls thene, the production of which is the object of all blossons.

Our photograph of Drummond's Dryas, fruiting on a gravelbar of a great northern river, was chosen because it ilhstrates so well the frequent beauty of this final stage in plint growth, and also the lavish manner in which seeds are ustally produced.

This plant forms dense mats of foliage above which in carly summer rise small, short-stemmod flowers. The petals wither. and the numerous styles afterwards dongate into twisted awns, fringed throughout their longth with fine hairs. While still immature these styles are tighty twisted togntlus, but when ripe they fluff out in to a downy ball two inches or more in thancter. The seed-stens lengthen to oight or ton inches, flums rasing the seed-hoarls well above the loavers.

As to the banty of such a bryas bed there can be no guestion. The soft, feathery expanse of plunose serels grlouning in the sunshine quite surpatses in attractiveness the silne hod when dotted with small yellow flowers. And sines this one colony shows thousands of serel-heads, and rach head has abont one humberl and fifty seeds, some idea of the gleat quantity of sered produerat is readily formed.

But, when the individual phant has ripened a good rorpof seed, the achieverment will be of litthe bederfit to the later unless the seeds

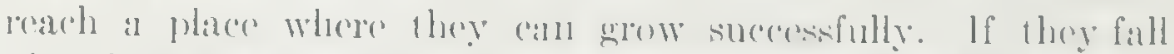

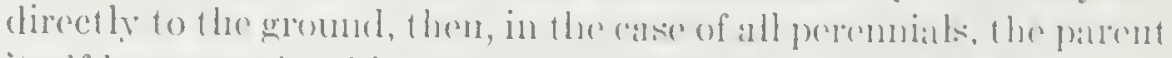

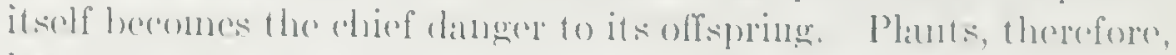

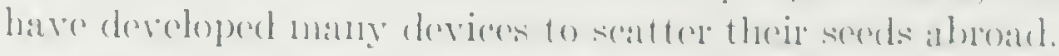

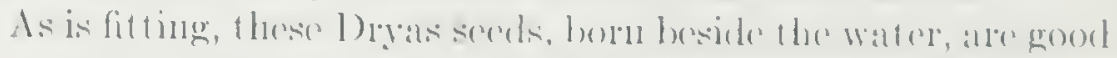
swimmors. They are atso alde to fly, althougle not with the buoyaney of thistle-domm. I sing both monkes of travele they

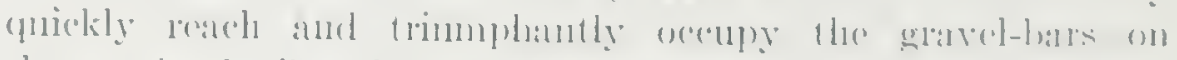
flomsinds of mike of merthern waterwates. 


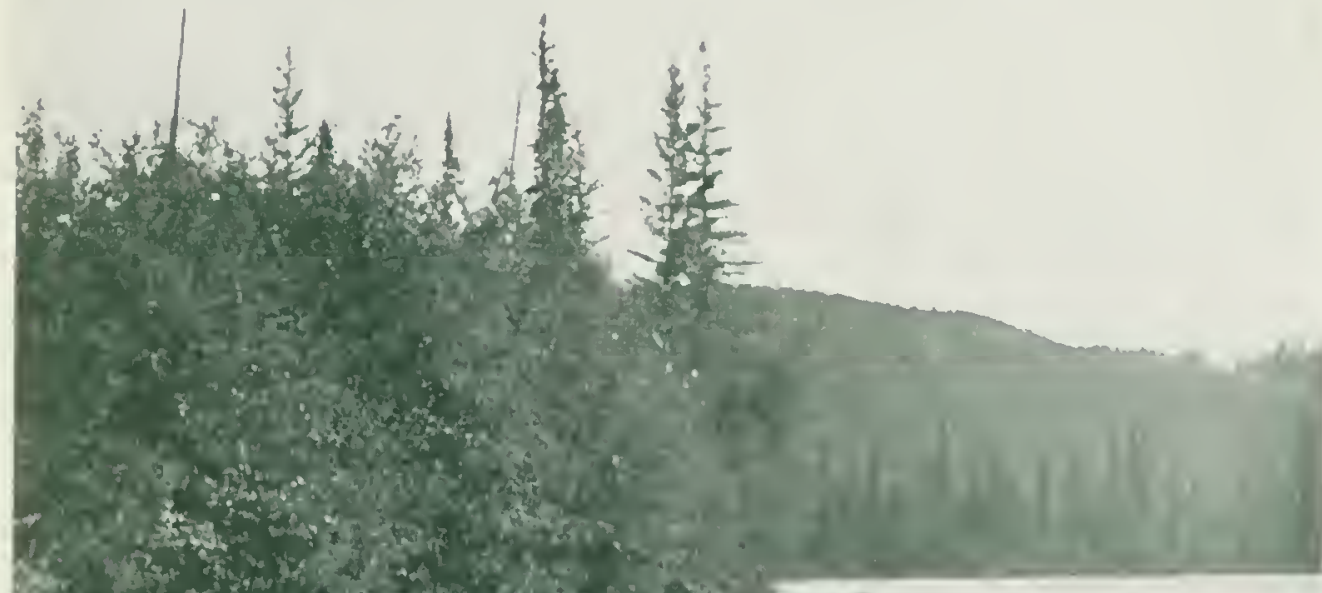

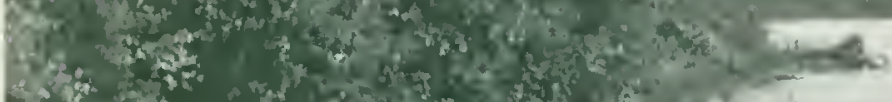

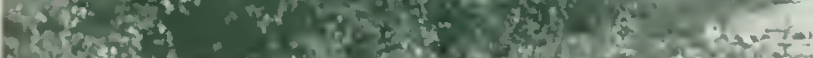

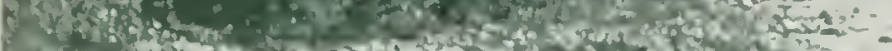

80 (j)

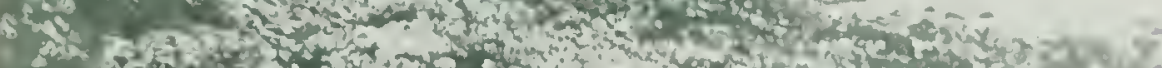

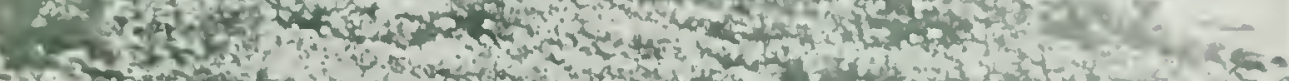

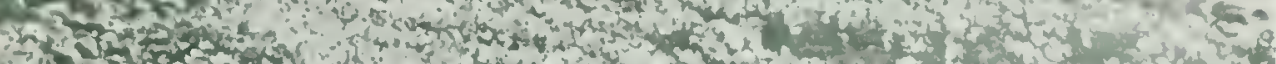

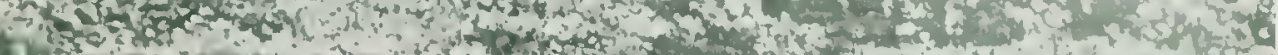

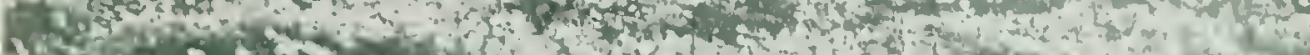

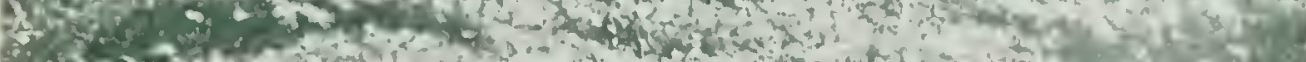

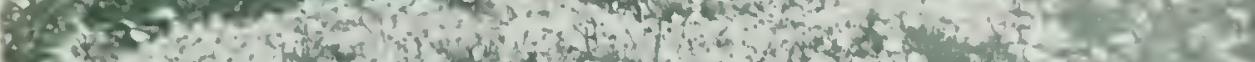
Q6.

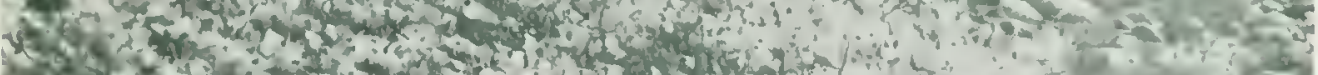

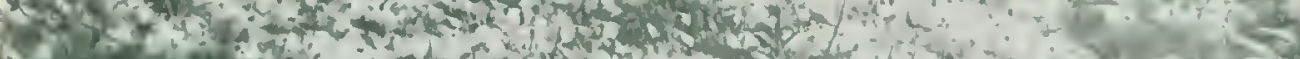

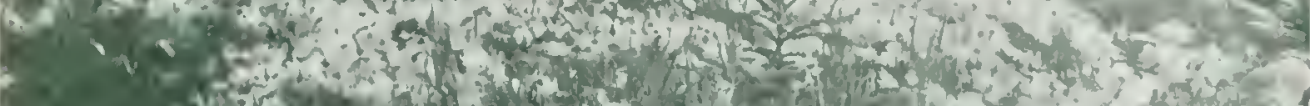

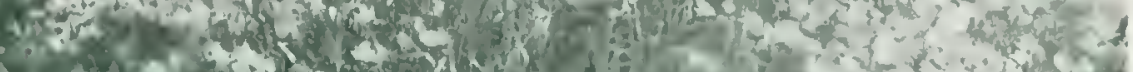

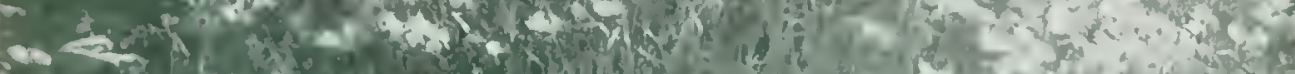

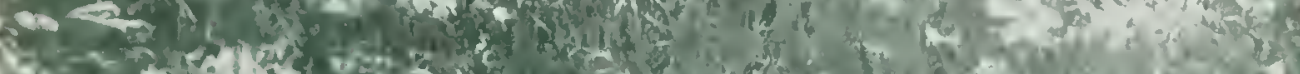

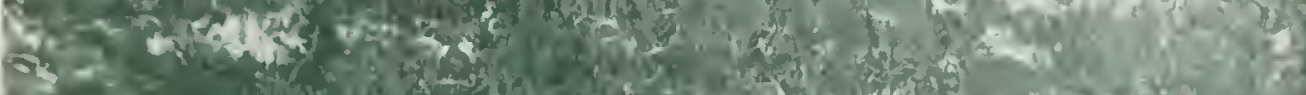

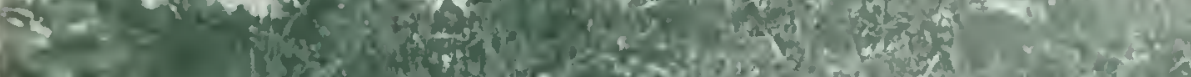

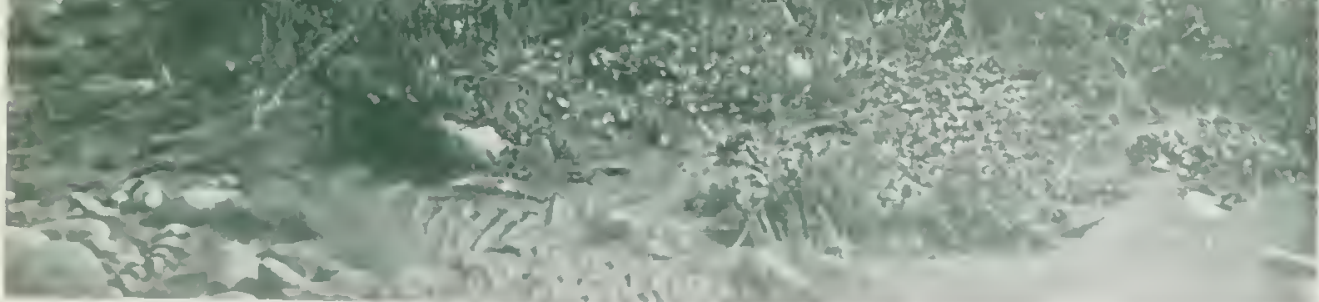

I)RLMIOND'S I)RYAS FIRUTIN(; ON A (;RAH.I-BAT 


\section{A GROUP OF AIRSHIP SEEDS}

\section{Ready to start on the great adventure}

Of the many methods of seed dispersion that of using the wind as carrier is one of the most common and most effective.

In the picture opposite we have an interesting group of such airship seeds. The centre is occupied by a spike of the great willow-herb, or fireweed, whose forty long pods conta ned about twelve thousand seeds On a dry day it is a pretty sight to see these pods splitting open, their four slender divisions curving quickly but gently outward into the form of a cross, and the imprisoned down instantly fluffing out as if delighted to find freedom. The seeds lose no time in starting on their momentous jounney, but eagerly commit themselves to the first passing breeze. The launching of these tiny, crowded airships is in open situations usually attended by few mishaps, and away they sail, each freighted with a potential fireweed that may by and by bloom in splendor on some distant clearing. These seeds are extremely light and buoyant. Twelve hundred of then weigh less than one grain, and in a still room, experiment showed that on the average the seeds took forty seconds to fall eight feet. The shightest upward breath of air sent them soaring, and in the open there is no doubt that they rise to great heights and travel long distances.

On the left of our picture are opened milkweed pods. Each hed about fifty large, brown seeds. These pods split open along one side only, and at first no silk is seen, for the flat seeds overtap one another like the seales of a spruce cone, but as drying progresses the elasticity of the compressed hairs pushes up and out secel after seed to be whirled away by the wind. The weight of each is more than one hundred times that of a fireweed secel, yet the sustaining power of its large and beautiful parachute is such that it has one-fifth the buoyancy of the lighter seed.

T'o the right are fore disintegrating eylinders of the longfruited anemene. While still intact, all the seeds-about two hundred and forty to each-are on the outside, arramged in wellcredered spirals with the wool tightly packed within. When the expansior pressure of this drying wool finally hersts the neat colinder, the crinlity wool separater into little tufts with a seed 


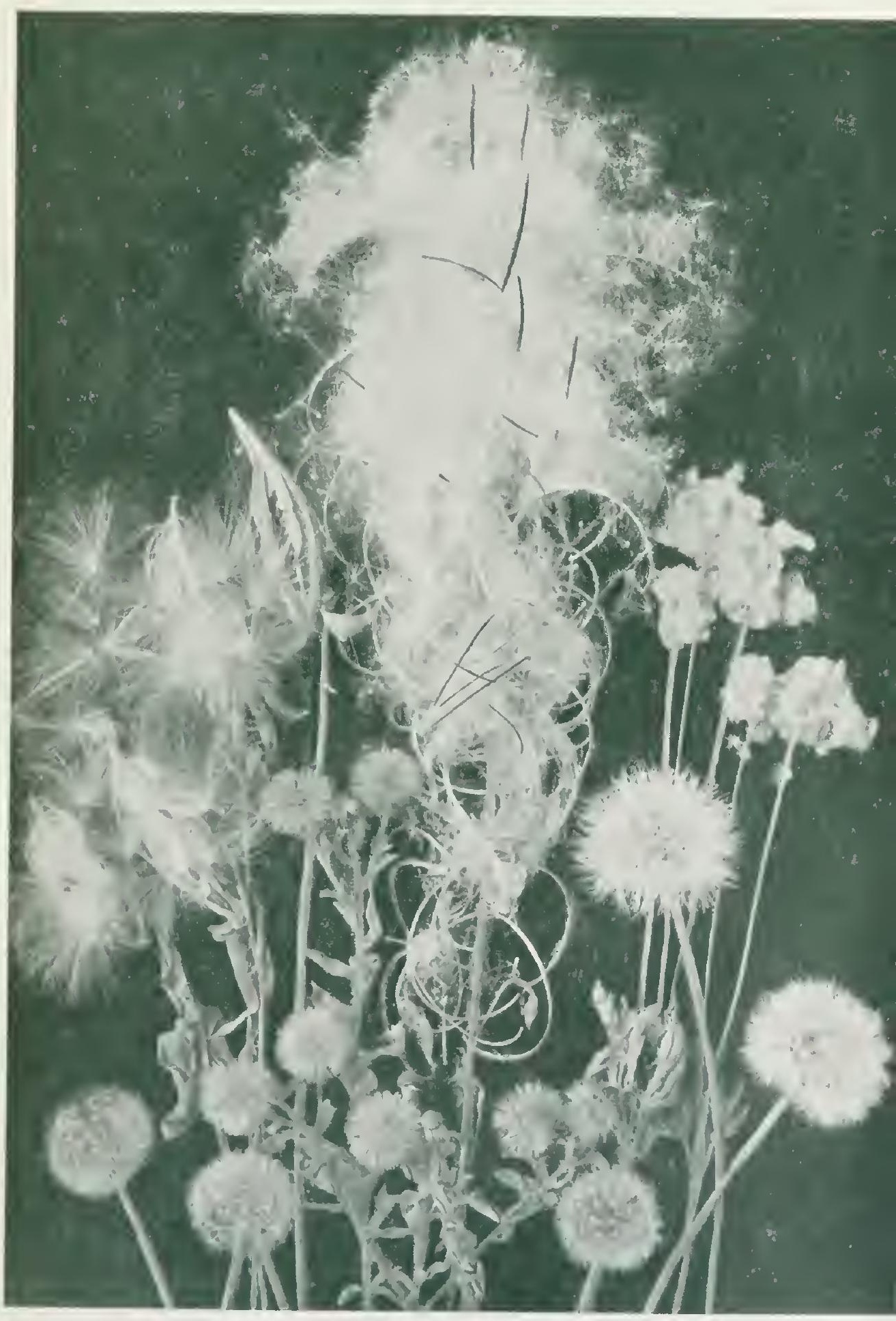

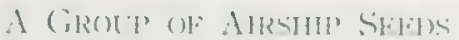


in the centre of each. These weigh fifteen times as much as, and have one-eighth the bouyaney of the fireweed seeds.

In the lower right hand corner are two heads of Troximom, an artistic ally of the dandelion. At the bottom are three globes of the dandelion itself, and above them the latf-dozen small hearls are those of the golden aster. These three plants bolong to the Thistle family and serve to illustrate the fruiting method of many of their kindred. As the dandelion, especially, is so wellknown it is unnecessary to describe this mothod in dofail. Wery child has played with dandelion " clocks" and watehed the seeds sail away before his vigorous puffs. "The dantelion seeds are quite light-about four hundred of them woigh one grainand yet in a quiet room their hnoyaney is only about one-tenth that of the fireweed seeds.

This comparison suggests that other factors play a part in the successful spreat of a species. From a close, hard fight the fireweed flies far away to seek easier combitions clsewhere, but the clandelion stays and fights it ont, suecessfully competing with even blue-grass sod, and dodging serious lawn-mower injury by spreading its leaves flat and hearing its flowers on very short stems. Then, just when the seek are rije, the stems shoot up and lift the sect-heats well above the grass. The dandelion seed may not travel so far as that of the fireweed, hut it will germinate and thrive where the latter would perish.

Here we must lave this interesting subject. The reater, however, maty by observation and simple experiment easily continue its investigation. 


\section{NDEX}

Page

Page

Agastarhe Fou mentum

Airship Seerls........ - 128

100 Cow P'arsuip.....

(is)

Sis

Allium cernuum.

Cowslip, Americ:in .

Anemone, Loug-frnited... .

$$
\text { "Virginian. }
$$

128

Crimberry ...

A pocynum androsacmifolium ..... 101

50

('rillo's-bill

Aquilegia flavescens. . . . . . .

Cypripedium parviflorum...

Aralia mudicaulis.

Aretic: Rasplocrry .

Dimlelion.

Artemisia frigida . . . .

Disporum trachycurpum

Asclepias otalifolia .

Aster commulatis. . .

121

Dolcrathcon pauciflorum

Doghanc, Spreading. .

" Civlilen...

130

Dogwood, lilowering.

"Showy Westru

124

“ Sinooth-leaved.

Dryas Drummondii

126

124

" White P'rairio.

" White Wroutl.

Astragalus hypoglottis

Dwarf Cornel.

Bakerl-apmole Berry. .

l'airy Bells....

Bcard-tongue, Blue.

Bedstraw, Nortleru

Berganiot.

Blazing Star

Blucbolls

Bunchberry

Butterfly Wered

Butterwort .

Button sinakeroot

Callu pulustris

Camas, Dritl

$$
\text { "White }
$$

Castilleja miniata

('inquefoil, 'Tall White

Cloutl-lerry

Columbine, sinall-flowered

Will..

Iollow

C'oneolvulus sepium

Gaillardia arislata

Galium boreale. . . . . . . . . . . . . 5. 5

Gaura coscinea.............. 72

Gerunium incisum . . . . . . . . . . . it

" Purpllo............ i.t

" Ticharikon's. . .....

" spotterl..... . . . .

Gitant Ilyssop. . . . . . . . . . . 10t)

Golken Peat............... . 10

Giriss of Parnassus. . . . . . . . . . 102

(ireat-flowered (iatillarelia ....... . 82

Itedge Bindweed. . . 
Hetysarum boreale............. 76

Pyrole aserifoliu.

$$
\text { " Maclicnzie. }
$$
76,114

Ilelianthus giganleus.

IIeracleum lanatum.

Indian Paint Brush............. 112

Labralor Tea................. 20

Lady's Slipper, Yellow.

liatris scariosa

110

Lilium monlanum.

56

Lily, Red or Wrool

Linnaea borealis.

Loco-weed . . .

Lungwort, 'Tall

Lygorlesmia juncra.

Meadow Rue, Tall............ s4

Mertensia paniculata.

$$
\text { "virginica. }
$$

Nills Vetch, Purple. .

Milkweed, Oval-leaverl.

Monarde mollis......

Homeses unifloru

Morning Giory

Northern Heelysarum.

Orchis rolundifoliu.

Oxytrope, Showy.

O.rylropis Lambreti.

Paintel Cup

I'amussia pralustris.

Prutstrmon prosertis.

P'elalostemem purpurens

Pitcher-plant .

I'lourogyme foneluma.

Potrutille anserrinus

$$
\text { “ } \quad \text { argulu } \ldots . .
$$

Polygala Senega.

Prairie 13and .

Pmirie ('lever, Purph

Prairie P'ink

I'rimrose, Birl'terye.

46

02,125

96

$1 i 2$

105

Ragwort, Marsh.... Bs, 40

Rouncl-leatod Orchis. . $\quad \ldots \quad: 32$

Rulues arclicus........ . 26

Rubus Chamaemorus.... 24

Singe Brush, Jorserer Pasture

122

Saraparilla, Wild

115

Sagnillaria latifolin

72

54

38

Sencea snukeroot ....

15. 36

Shooting Star....

:30

30

ii2

70

20

$\therefore 0$

26

116

Thalidrum purpuresses us

$\$ 1$

10

130

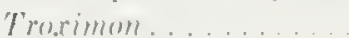

76) Тพй-fower. . . .

$14 i$

86 Vinket, Litrly Purple

2N

112 Wistr. Armm..

102 Winter-crowfout

34 Wrotem River sone. 1

30) Villow-herl, (ireat. .

100. 13:

titi Winterereen, One-flowered

it Wintereren, l'ink.....

Iormwoxl sigge. . . . . 




\section{Date Due}

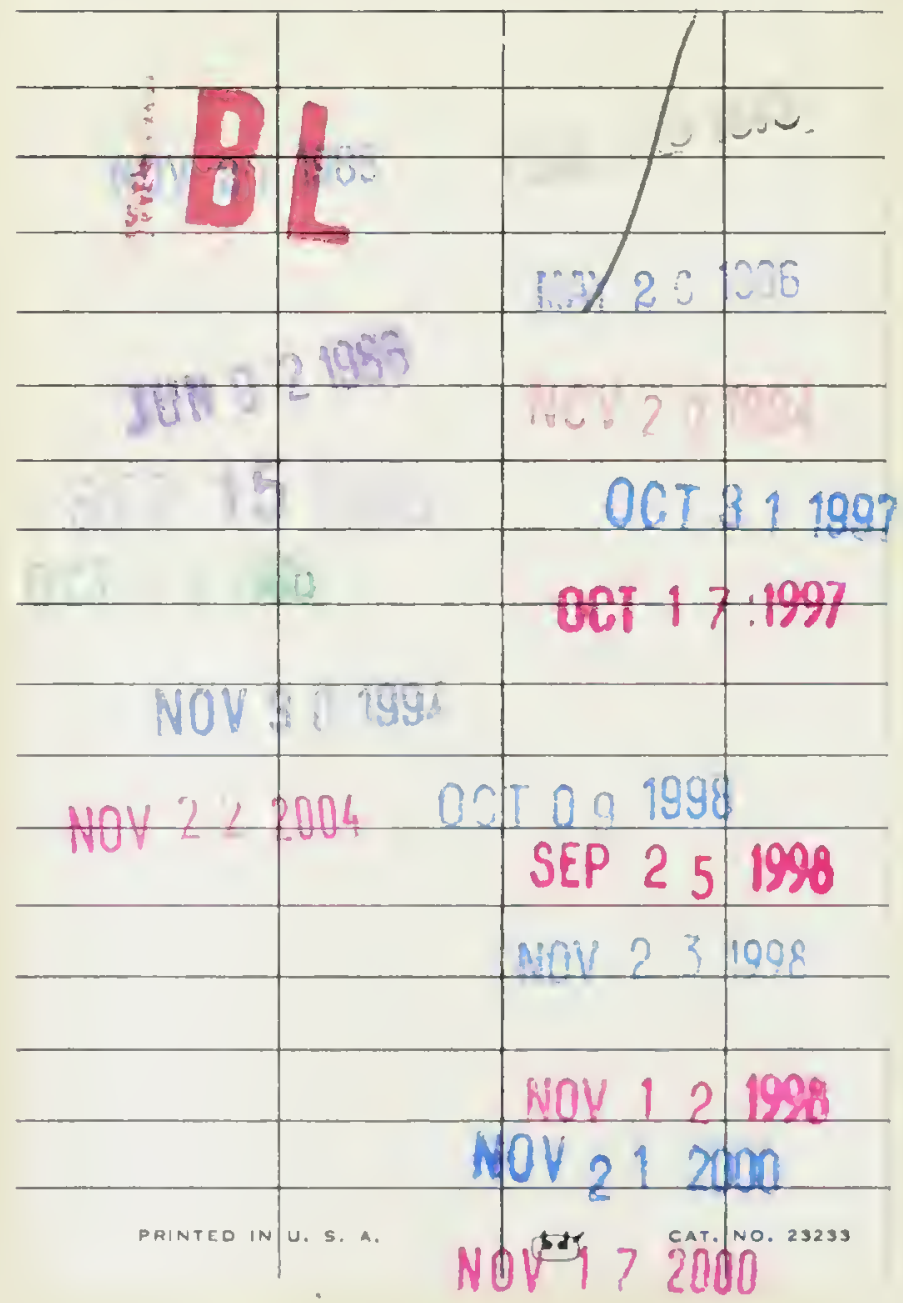


QK201 .1:25

licCalla, William copeland.

Wild flowers of Western Canada.

ISSUED TO

\section{2}


